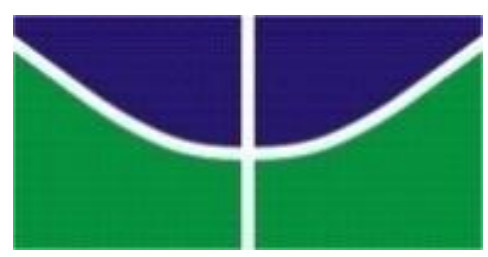

Universidade de Brasília - UnB

Programa de Pós-Graduação em Biologia Animal

Departamento de Genética e Morfologia

Laboratório NanoGen

\title{
NANOPARTÍCULAS MAGNÉTICAS RECOBERTAS COM CITRATO E NANOCÁPSULAS CONTENDO SELOL NO TRATAMENTO DO ADENOCARCINOMA MAMÁRIO DE EHRLICH ORTOTÓPICO EM CAMUNDONGO SWISS
}

\section{Cesar Romero Soares Sousa}


Universidade de Brasília - UnB

Programa de Pós-Graduação em Biologia Animal

Departamento de Genética e Morfologia

Laboratório NanoGen

\section{NANOPARTÍCULAS MAGNÉTICAS RECOBERTAS COM CITRATO E NANOCÁPSULAS CONTENDO SELOL NO TRATAMENTO DO ADENOCARCINOMA MAMÁRIO DE EHRLICH ORTOTÓPICO EM CAMUNDONGO SWISS}

CESAR ROMERO SOARES SOUSA

Tese apresentada ao Programa de PósGraduação em Biologia Animal do Instituto de Ciências Biológicas da Universidade de Brasília como requisito parcial para a obtenção do título de Doutor.

ORIENTADORA: Prof ${ }^{\mathrm{a}}$. Dra ${ }^{\mathrm{a}}$. Zulmira Guerrero Marques Lacava CO-ORIENTADORA: Prof ${ }^{\mathrm{a}}$. Dra ${ }^{\mathrm{a}}$. Ana Luisa Miranda-Vilela

BRASÍLIA - DF 


\section{NANOPARTÍCULAS MAGNÉTICAS RECOBERTAS COM CITRATO E NANOCÁPSULAS CONTENDO SELOL NO TRATAMENTO DO ADENOCARCINOMA MAMÁRIO DE EHRLICH ORTOTÓPICO EM CAMUNDONGO SWISS}

Prof ${ }^{a}$ Drª. Zulmira Guerrero Marques Lacava (UnB) (Orientadora)

Prof ${ }^{a}$. Drạ. Marcella Lemos Brettas Carneiro (UnB)

(Examinador externo)

Prof ${ }^{\text {a. }}$. Dr ${ }^{\mathrm{a}}$. Andrea Barretto Motoyama (UnB)

(Examinador Externo)

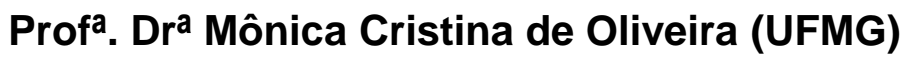

(Examinador Externo)

Prof ${ }^{\text {. Dra }}$. Maria de Fátima Menezes Almeida-Santos (UnB) (Examinador Interno)

Prof. Dr. João Paulo Figueiró Longo (UnB)

(Examinador Interno)

Brasília, de de 2015 
A minha amada família; mãe, Heny Bianque, esposa, Maria do Carmo, filhos; Cesar Romero Junior e Keiko Perpetuo, irmãs; Dúlcina, Marlene e Iêda, que sempre me incentivaram a conquistar mais esta vitória.

Minhas humildes e sinceras desculpas por longos períodos ausentes. $\mathrm{O}$ tempo de nossa convivência "roubado" pela tese só fez fortalecer a vontade de estar junto de vocês. 


\section{A GRADECIMENTOS}

Agradeço a Deus por sempre me iluminar e guiar meus caminhos

Às Professoras Zulmira Lacava e Ana Luisa, pela força, confiança e grandes oportunidades, sempre me orientando e guiando com relevância para ser um cientista produtivo. Fontes inesgotáveis de generosidade e sabedoria "condensadas" cujo caminho de retidão guiou meus passos até aqui. Muito obrigado.

Ao Professor Marcos Célio de Almeida, tenho muito orgulho de citá-lo como um dos responsáveis pela minha formação profissional, por ter me incentivado à pesquisa como forma de criação e melhorias para a vida humana, obrigado por estar constantemente solícito, com paciência, sapiência e aconselhamentos.

Um especial acradecimento ao professor Antônio Sebben, o senhor é um exemplo de simplicidade, compreensão e competência.

À Profa. Emília Celma de Oliveira Lima, do Instituto de Química (IQ) da Universidade Federal de Goiânia (UFG), pela o fornecimento da amostra NPcit.

Aos professores Cesar Grisolia, Kelly Greice, Maria Luisa, Mônica Garcia, Ricardo Bentes, Sacha Braun, que sempre me ajudaram quando eu mais precisava

A mi querida Leia Loiola, profesora de Español, por ayudarme siempre en las revisiones.

Ao Dr. Piotr Suchocki do Departamento de Análises de Drogas de Varsóvia, Polônia, pelo fornecimeto do Selol.

A Rejane Rosa, minha psicóloga e revisora de plantão.

Aos colegas de Bancada, Flávia, Iérlei, Laise, Lane, Lívia, Mariana Campos e Willie, que são minhas fontes de inspiração e admiração.

Aos meus pupilos (estagiários): Fernanda Medeiros, Gabriel Ribeiro, Giseli Lorrana, Juliana Menezes, Lucas Simino, Naissa de Sousa, Wanessa Pedroso, Ronald Torres e Sâmara Vainauskas (almas gêmeas).

Ao alunos, colegas, professores e direção do Centro de Ensino Fundamental de Ceilândia (CEF 27) pela compreensão, apoio e incentivo nos momentos de correria e desespero: Aldevi Junior (Junior Pezão), Ana Paula, Cristina Freitas, Elizete Alves, Geraldo Junior, Jaciara dos Santos, Leonardo Capuzzo, Mara Freitas, Maria Jucenilde, Rodrigo Alves e Shirley Alves.

Aos meus amigos Wânia Guimarães e Msc. Antônio Djalma por estarem sempre dispostos a me ajudar. 
Aos meus queridos alunos e estagiários da FACIPLAC que me suportaram, sempre aos sábados e domingos da vida.

Os meus amigos da manutenção da UnB, Gilberto Guimarães (Bombeiro hidráulico) e Evangelista Carvalho (Marceneiro) sempre me socorrendo e construindo minhas "inventices".

A Jose de Sousa Filho (in memoriam), Ana Ligia, Jaqueline Silva, Zelia Madeira, Jivago de Paula, pela ajuda sempre.

À Susan Casement, pela revisão do Abstract e do inglês dos artigos deste trabalho.

Ao Alexandre Vasconcelos Lima, pela estatística deste trabalho.

Ao Conselho Nacional de Desenvolvimento Científico e Tecnológico (CNPq), à Coordenação de Aperfeiçoamento de Pessoal de Nível Superior (CAPES), à rede CONNANO (CAPES), INCT-Nanobiotecnologia (CNPq/MCT), FAPDF (Fundação de Apoio a Pesquisa do Distrito Federal) pelo apoio financeiro.

Ao Laboratório Sabin, através do Núcleo de Apoio a Pesquisa (BSB- IS-NAP), pela realização das análises hematológica e bioquímica.

A todos os amigos e parentes que direta ou indiretamente me ajudaram na realização deste trabalho.

\section{Tributo aos grandes e não lembrados heróis das ciências}

Na ficção temos homenageado, há décadas, um limitado elenco de camundongos e ratos famosos. São pequenas estrelas que brilham em filmes, estórias infantis e contos de fadas.

$\mathrm{Na}$ realidade, milhões de camundongos que participam de experimentos e pesquisas importantíssimas, passam por nossa história no anonimato.

Presto aqui minha homenagem a esses pequenos heróis, grandes colaboradores da nossa ciência.

Zélia Ramos Madeira 


\section{S UMÁ R I O}

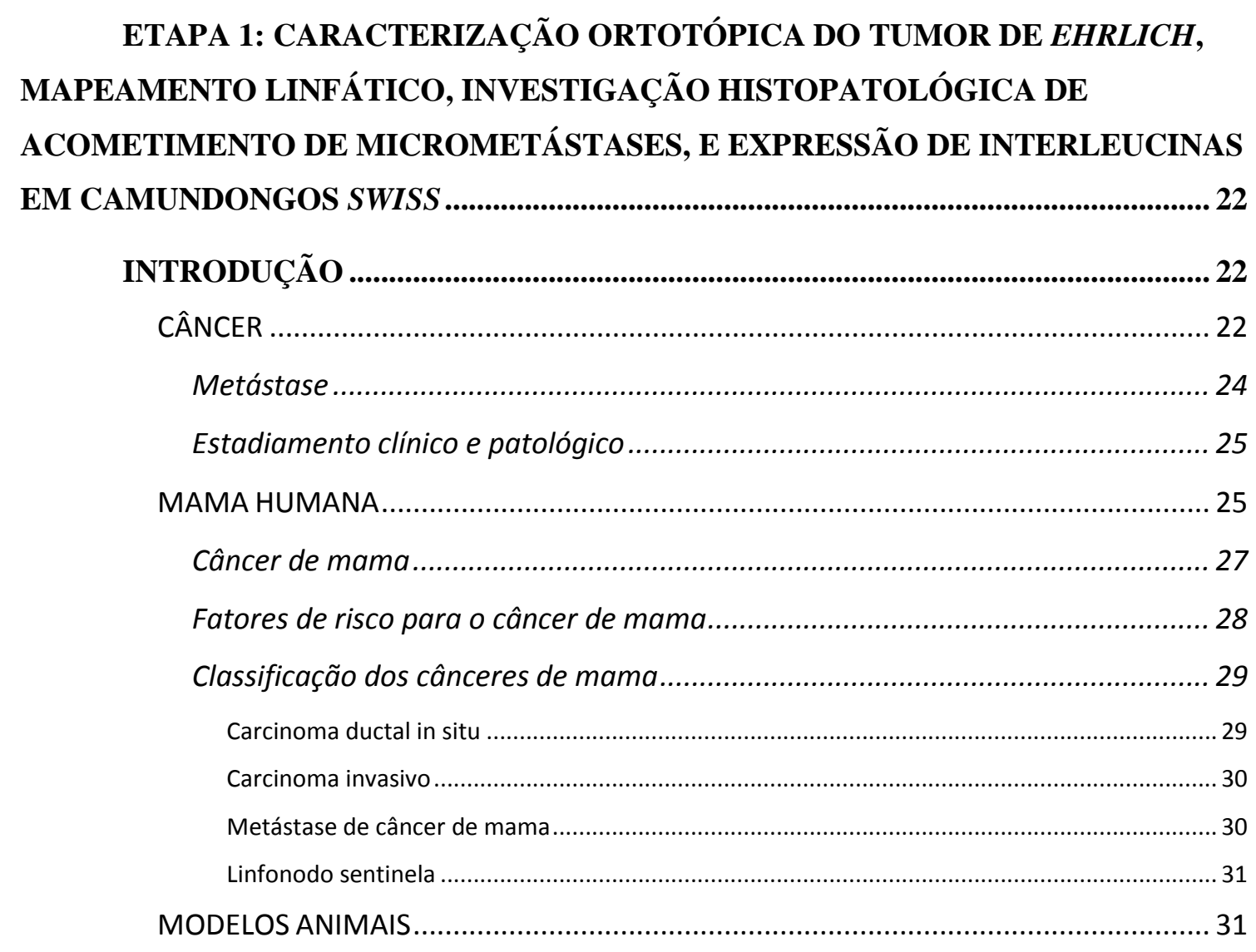

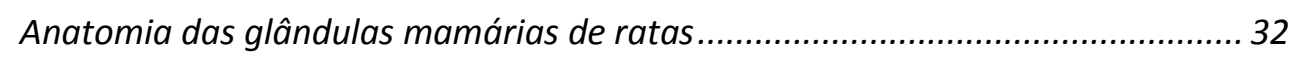

Distribuição e nomenclatura dos linfonodos ........................................................ 33

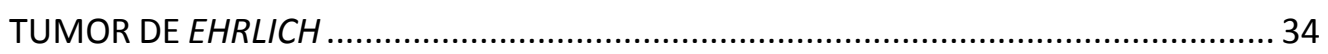

Transplante tumoral e inoculação ortotópica do tumor de Ehrlich....................... 36

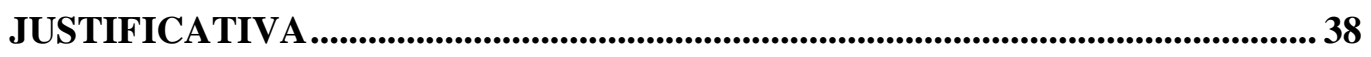

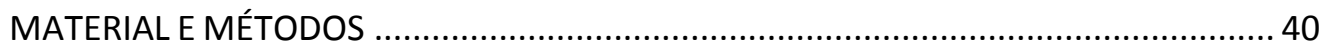

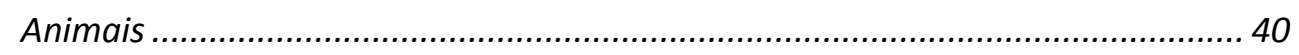

Microanatomia Mamária de Camundongos Swiss............................................. 40

Microdisseç̧ão Mamária em Camundongos Swiss............................................ 41

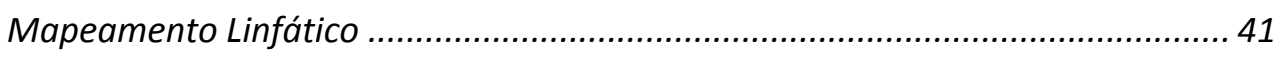

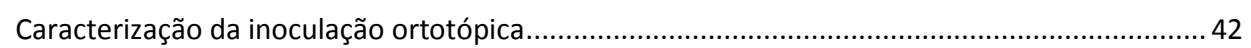

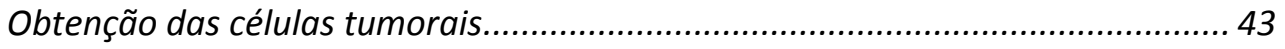

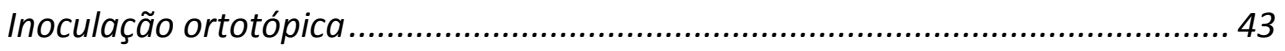

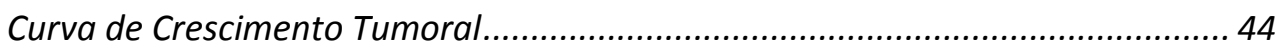

Avaliação do volume tumoral para determinação da curva de crescimento ........ 45

Avaliação histopatológica e clínica do tumor obtido por inoculação ortotópica .. 45 
Dosagem de proteína dos fragmentos tumorais

Dosagem de interleucinas nos fragmentos tumorais .................................... 47

Caracterização do tumor por ecografia...................................................... 48

Caracterização do tumor por microtomografia computadorizada (MCT)............. 48

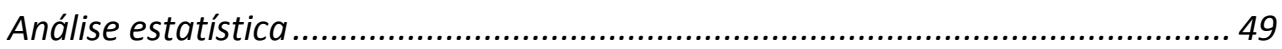

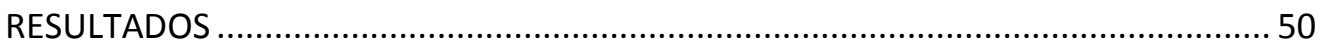

Microanatomia da mama do camundongo Swiss ............................................ 50

Mapeamento linfático e Linfonodo Sentinela (LNS) de animais saudáveis e portadores de tumor....................................................................................... 51

Avalição clínica, evolução e mensuração tumoral............................................ 54

Curva de Crescimento Tumoral..................................................................... 54

Análise histológica de órgãos e tumores ..................................................... 58

Análise de imunomodulação por TE ......................................................... 59

Caracterização do tumor por imagens em camundongos portadores de tumor por

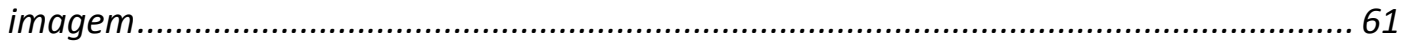

Microtomografia computadorizada ..................................................... 61

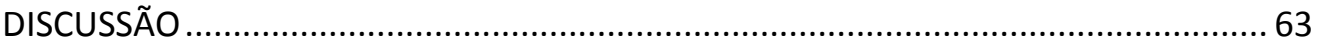

ETAPA 2: MAGNETOHIPERTERMIA E QUIMIOTERAPIA PARA

TRATAMENTO DE ADENOCARCINOMA MAMÁRIO DE EHRLICH EM

CAMUNDONGO SWISS: USO DE NANOPARTÍCULAS DE MAGHEMITA

RECOBERTAS COM CITRATO E NANOCÁPSULAS DE POLIETILENO GLICOL

CONTENDO SELOL ................................................................................................ 68

INTRODUÇÃ

Magnetohipertermia ...................................................................... 70

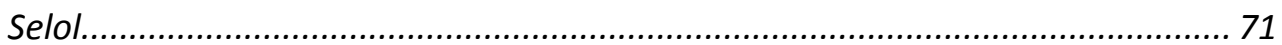

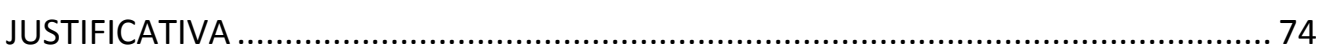

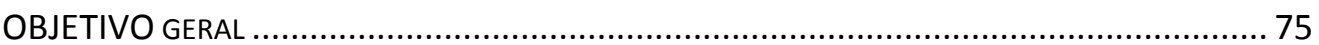

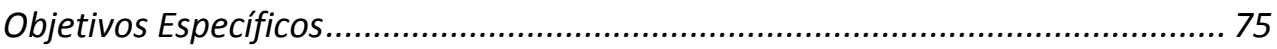

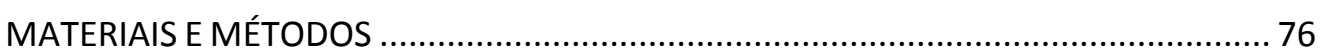

Equipamentos para magnetohipertermia (MHT) ..................................... 76

Equipamento gerador de campo magnético AC (tratamento 1) - equipamento Magnetherm. .. 76

Equipamento gerador de campo magnético AC (tratamento 2) - equipamento CMagMHG....... 77

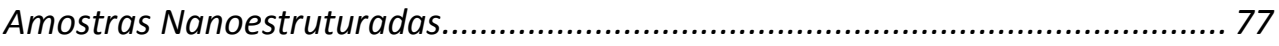

Nanopartículas magnéticas recobertas com citrato (NPcit) (Tratamentos 1 e 2) .......................... 77

Nanocápsulas de PLGA contendo compostos ricos em selênio (Tratamentos 1 e 2) .................... 77 
Caracterização das amostras por Microscopia Eletrônica de Transmissão................................ 78

Caracterização das amostras por Microscopia Eletrônica de Varredura (MEV) ............................ 79

Determinação do tamanho hidrodinâmico e potencial Zeta das amostras por Espalhamento de Luz Dinâmica

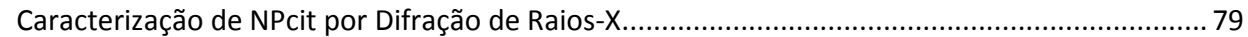

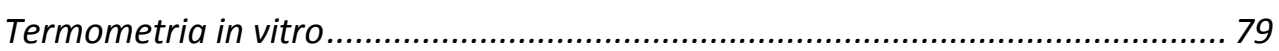

Controle de qualidade do ativo (Selol).............................................................. 80

Distribuição e parâmetros clínicos (Tratamento 2) ......................................... 80

Tratamento (1) equipamento (Magnethterm) e Tratamento (2) equipamento

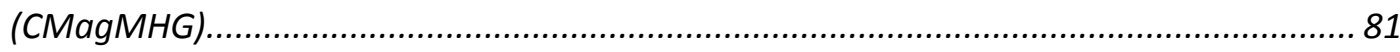

Tratamento 1, equipamento Magnetherm ................................................ 81

NPcit = Nanopartículas magnéticas recobertas com citrato; nanocápsulas de PLGA contendo Selol; NPsel= CMag = campo magnético AC.

Tratamento 2, equipamento CMagMHG.

NPcit = Nanopartículas magnéticas recobertas com citrato; nanocápsulas de PLGA contendo Selol; NPsel= CMag = campo magnético AC. Error! Bookmark not defined.

NPcit = Nanopartículas magnéticas recobertas com citrato; nanocápsulas de PLGA contendo Selol; NPsel= CMag = campo magnético AC. .85

Investigação do processo metastático e identificação dos LNS e LNCL .85

Avaliação do potencial genotóxico por análise dos parâmetros de Fragmentação de DNA e Ciclo Celular (Tratamento 2) 86

Avaliação Hematológica e Bioquímica (Tratamento 2)........................................ 86

Sobrevida de Animais Tratados com Terapia Combinada ................................... 87

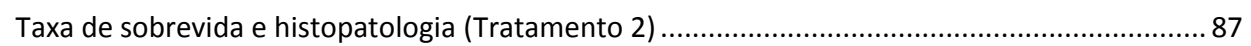

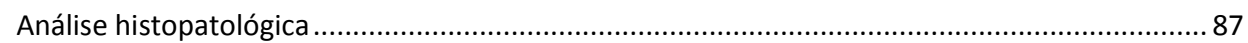

Caracterização das Nanopartículas magnéticas recobertas com citrato (NPcit) .. 88

Caracterização das Nanocápsulas de PLGA contendo Selol (NPsel)..................... 89

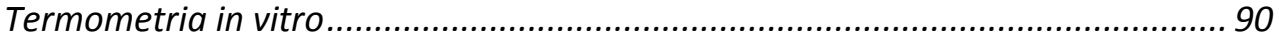

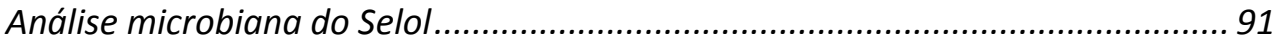

Caracterização da presença de NPcit por MCT e distribuição por análise

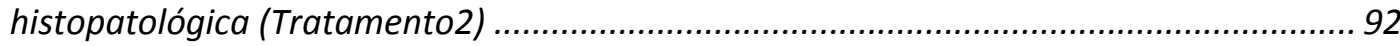

Investigação do processo metastático e identificação dos LNS e LNCL................. 92

Avaliação do potencial genotóxico por análises dos parâmetros de fragmentação de DNA e ciclo celular (Tratamento 2)................................................................. 94

Hematologia e Bioquimica do Tratamento 2................................................ 95 
Hematologia

Variação ponderal dos animais tumor e peso do baço (tratamento2)............... 101

Status Linfonodal dos Grupos do Tratamento 2 .............................................. 104

Acometimento de micrometástases nos LNS e LNCL tratamento 2 …..................................... 104

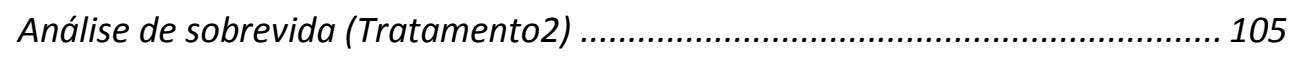

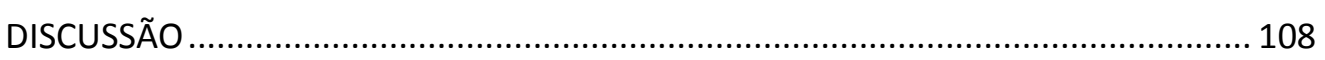

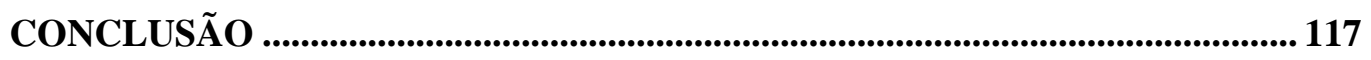

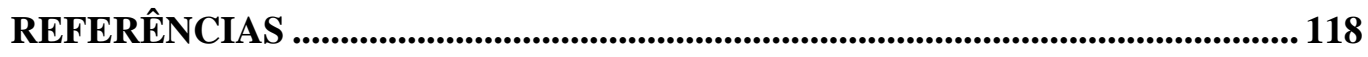

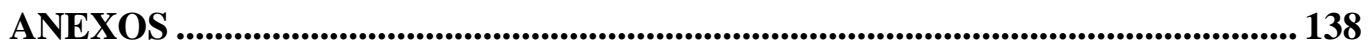

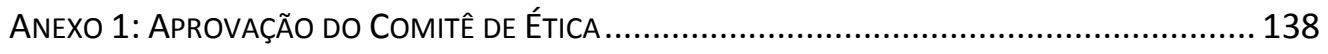

ANEXO 2: DECLARAÇÃO DO COMITÊ DE ÉTICA .................................................. 139

ANEXO 3: PROTOCOLO 01 - AZUL DE TRIPAN INOCULADO ........................................... 140

ANEXO 4: PROTOCOLO 02 - AZUL DE TOLUIDINA IN SITU ............................................. 141

ANEXo 5: PROTOCOLO 03 - AZUL DE TRIPAN INOCULAdo E AZUL DE TOLUIDINA ..................... 142

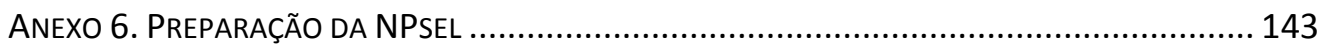




\section{LISTA DE FIGURAS}

Figura 1: Desenho esquemático da localização dos gânglios linfáticos de camundongos BALB/cAnNCrl. 34

Figura 2: A foto ilustra o procedimento de inoculação do corante Azul de Tripan na quinta glândula mamária esquerda em um camundongo Swiss fêmea. 41

Figura 3: Grupos de inoculação ortotópica $(n=5)$, células TE frescas e congeladas.

Figura 4: Detalhes da inoculação ortotópica. .................................................. 44

Figura 5: Representação da distribuição das glândulas mamárias em camundongo Swiss.

Figura 6: Glândula mamária de camundongo Swiss fêmea: fotografia da $5^{\text {a }}$ glândula mamária (inguinal) de animal com 55 dias de idade

Figura 7: Detalhe macroscópica da glândula mamária de camundongo lactante.

Figura 8: Mapeamento linfático e linfonodo sentinela (LNS) da $4^{\mathrm{a}}$ e $5^{\mathrm{a}}$ (direita) glândulas mamárias normais

Figura 9: Caracterização do tumor de Ehrlich in situ 24 horas após inoculação de células tumorais TE frescas.

Figura 10: Evolução tumoral 7, 14 e 21 dias após inoculação de células TE congeladas por 30 dias 56

Figura 11: Evolução tumoral 7, 14 e 21 dias após inoculação de células TE frescas 56

Figura 12: Fotografia dos aspectos macroscópicos tumorais no sítio de inoculação do TE, (in situ) e após microdissecção células frescas com 7 dias de inoculação.

Figura 13: Curva de crescimento tumoral após inoculação ortotópica de $100 \mu \mathrm{L}$ de $1 \times 10^{6}$ células frescas (linha vermelha) e congeladas (linha Azul) TE em camundongo Swiss.

Figura 14: Crescimento tumoral 7 dias após inoculação ortotópica de $10 \mu \mathrm{L}$ ou $100 \mu \mathrm{L}$ de células frescas TE, em ambos experimentos foram utilizadas $1 \times 10^{6} \mathrm{de}$ células 58

Figura 15: Caracterização histológica do tumor após 7 dias (A-F), 14 dias (G-J) e 21 dias (K-L) 
Figura 16: Ecografia da região mamária de camundongo (inguinal direita), realizada 24 horas após implante de células TE frescas

Figura 17: Microtomografias computadorizadas (MCT) da parede abdominal no plano axial e vista inferior

Figura 18: Equipamento gerador de campo magnético de frequência alternada (MagneTherm, NanoTherics) 76

Figura 19: A) equipamento gerador de campo eletromagnético de frequência alternada; B) Solenoide com haste móvel; C) Animal se submetendo ao campo magnético; D) Cronógrafo; E) Termômetro digital de múltiplos canais; F) Fonte de calor e G) Animal em recuperação após exposição ao campo magnético AC (pósanestésico).

Figura 20: Imagem de NPcit obtida por MET. Diâmetro médio das NPM. Distribuição de tamanho (NPcit) obtida pela contagem de 348 NPM. 89

Figura 21: Micrografia eletrônica de varredura (MEV) de nanocápsulas contendo Selol. 90

Figura 22: Curva de aquecimento da amostra nopartículas magnéticas recobertas com citrato em função do tempo e da quantidade de amostra usada. 91

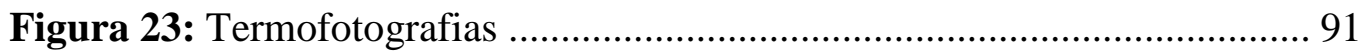

Figura 24: Distribuição de NPM por MCT e histologia do tumor .................... 93

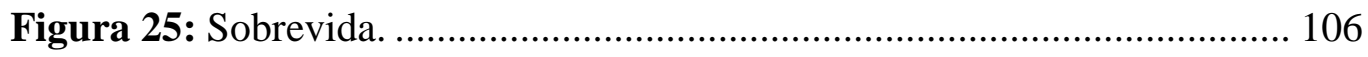

Figura 26: Histologia de um animal do grupo sobrevida G2 ...................... 107 


\section{LISTA DE TABELAS}

Tabela 1: Estimativas de novos casos de câncer para o ano de 2014 (taxa bruta de incidência por 100 mil habitantes), segundo sexo e localização primária. 23

Tabela 2: Plano de cortes de inclusão em parafina para histologia .................. 47

Tabela 3: Tratamento 1, equipamento Magnetherm....................................... 82

Tabela 4: Características do Npcit, FM baseado em NPM de maghemita $(\gamma-$

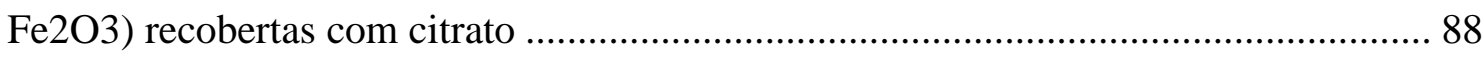

Tabela 5: Características das Nanocápsulas de PLGA contendo Selol ............. 89

Tabela 6: Acometimento por metástases do Linfonodo Sentinela (LNS) e do Linfonodo Contralateral (LNCL) dos animais acometidos por TE ortotópico. .............. 94

Tabela 7: Hematologia dos animais do grupo Tratamento 2.......................... 99

Tabela 8: Bioquímica dos animais do grupo Tratamento 2 .......................... 100

Tabela 9: Peso dos animais e peso do baço dos animais Tratamento 2.......... 102

Tabela 10: Volume e peso do tumor - Tratamento 2 ................................... 103

Tabela 11: Acometimento de metástase no LNS, LNSCL e órgãos ................ 105 


\section{LISTA DE ABREVIATURAS E SIGLAS}

a.C - Antes de Cristo

ABM - Agaricus Blazei Murrill

ALT - Alanina Aminotransferase

ANOVA - Análise de Variância

AST - Aspartato Aminotransferase

BRCA1 - breast cancer 1

BRCA2 - breast cancer 2

CAPES - Coordenação de Aperfeiçoamento de Pessoal de Nível Superior

CEMIB - Centro Multidisciplinar para Investigação Biológica na Área da Ciência em

Animal de Laboratório

CHCM - Concentração de Hemoglobina Corpuscular Média

CMag - Campo Magnético

$\mathrm{CN}$ - Controle Negativo

CNPq - Conselho Nacional de Desenvolvimento Científico e Tecnológico

CV - Corante vital

DL - Ductos lobulares

DLS - Dynanics Light Scattering

DMEM - Modified Eagle's Medium Nutrient Mixture

DMSO- Dimetilsulfóxido

DNA- ácido desoxirribonucleico

DP - Ducto principal

DRX - Difração de Raios X

DT - ductos terminais

DXR - Doxorrubicina

EDTA - Etilenodiamino Tetra-acético

ER - estrogênio

ERO - Especies reativas de oxigêneo

EVA - etileno vinil acetato

FM - Fluido Magnético

Formvar - Formal de Polivinil

GEM - Departamento de Genética e Morfologia 
GGT - Gama Glutamil Transferase

HCM - Hemoglobina Corpuscular Média

HE - Hematoxilina-Eosina

IB - Instituto de Ciências Biológicas

IL - Interleucina

INCA - Instituto Nacional de Câncer

Ip - Intraperitoneal

IQ- Instituto de Química

IRM - Imagem por Ressonância Magnética

LNCL- Linfonodo contralateral

LNS - linfonodo sentinela

MCT - Microtomografia Computadorizada

MET - Microscópio Eletrônico de Transmissão

MEV - Microscópio Eletrônico de Varredura

MHT - Magnetohipertermia

NPsel - Nanocápsula de Selol

NPcit - Nanopartículas de Maghemita Recobertas com Citrato

NPM - Nanopartículas Magnéticas

OMS - Organização Mundial da Saúde

$\mathrm{P}$ - Papila mamária

PBS - Phosphate Buffered Saline

PDI - Índice de Polidispersão

pH - Potencial de Hidrogênio

PLGA - ácido poli láctico-co-glicólico

PTX- Paclitaxel

RDW - Red Cell Distribution Width

RMN - Ressonância Magnética Nuclear

SFB- Soro fetal bovino

SPSS - Statistical Package for the Social Sciences

TAE - Tumor Ascítico de Ehrlich

TE - Tumor de Ehrlich

TGO - Transaminase Glutâmica Oxalacética

TGP - Transaminase Glutâmica Pirúvica

TMB - tetrametilbenzidina $36 \mathrm{mM}$ 
TNM - Tumor-Nodo-Metástase

UFG- Universidade Federal de Goiás

UICC - União Internacional Contra o Câncer

UnB - Universidade de Brasília

Unicamp - Universidade Estadual de Campinas

VCM - Volume Corpuscular Médio 


\section{RESUMO}

O câncer de mama continua a ser a causa mais comum de morte por câncer entre as mulheres em todo o mundo, independentemente do surgimento e evolução de novas abordagens terapêuticas. Assim, para entender os mecanismos fundamentais por trás da malignidade e também contribuir para a descoberta de métodos melhorados para a prevenção, diagnóstico e tratamento, os modelos de câncer em animais continuam a ser essenciais. Este trabalho teve como foco avaliar alguns destes parâmetros do câncer de mama e foi desenvolvido em duas etapas. Na primeira etapa, o objetivo foi estabelecer um modelo ortotópico ideal de câncer de mama em camundongos Swiss, com caracterização anatômica e por microtomografia computadorizada (MCT), investigação histopatológica de acometimentos de micrometástases, mapeamento linfático e expressão de interleucinas (IL). Como resultado, foi possível observar tumor detectável 24 horas após inoculação de células frescas de tumor de Ehrlich (TE) e, após 7 dias de inoculação, invasão mamária, linfática, muscular e vascular dérmica, além de micrometástases em tecido adiposo mamário, linfonodo sentinela (LNS) e linfonodos contralaterais. Níveis de citocinas pro-inflamatórias Th1 (IL-1 $\beta$ e IL-17) foram significativamente mais elevados do que níveis de citocina anti-inflamatória Th2 (IL-4) após a inoculação de células tumorais frescas em camundongos Swiss. Diferentemente, células tumorais congeladas induziram o desenvolvimento do tumor apenas 14 dias após a inoculação, apresentando também expressão de interleucinas distintas. Na segunda etapa do trabalho, o objetivo foi usar esse modelo ortotópico desenvolvido para testar uma nova abordagem terapêutica, usando duas terapias combinadas, magnetohipertermia (MHT) e quimioterapia antioxidante, ambas baseadas em materiais nanoestruturados. Para tal, $1 \times 10^{6}$ células tumorais frescas de Ehrlich $(100 \mu \mathrm{L})$ foram inoculadas na quinta glândula mamária direita. Após 24 horas e com o tumor já implantado $\left(200 \mathrm{~mm}^{2}\right)$, procedeu-se com os seguintes tratamentos por via intratumoral: (1) inoculação de $110 \mu \mathrm{L}$ de nanopartículas magnéticas recobertas com citrato (NPcit) na concentração de $18 \times 10^{18}$ partículas $/ \mathrm{mL}$, seguida por MHT, realizada em equipamento operando a $1 \mathrm{MHz}$ e 40 Oe de amplitude de campo; (2) inoculação de 100 $\mu \mathrm{L}$ de nanocápsulas de PLGA (ácido poli láctico-co-glicólico) contendo $10 \mathrm{mg} / \mathrm{mL}$ de Selol 5\%, Nanocápsula de Selol (NPsel); e (3) terapia combinada com MHT e NPsel. O controle negativo $(\mathrm{CN})$, animais saudáveis, recebeu $100 \mu \mathrm{L}$ de solução salina via intraperitoneal (Ip), o controle positivo recebeu Paclitaxel (16 mg/Kg) em uma única 
injeção intraperitoneal $(50 \mu \mathrm{L}) 24$ horas após a inoculação do tumor, e o controle tumor não recebeu nenhum tratamento. Para avaliar a eficácia dos tratamentos em conter o crescimento tumoral, foram avaliados volume e peso tumorais, além de avaliações histopatológicas da mama inoculada, mama contralateral, LNS e linfonodo contralateral (LNCL). Para avaliar a possível toxicidade dos tratamentos, utilizou-se, além da avaliação clínica dos animais e índice de sobrevida, análises hematológicas, bioquímicas, histopatológicas de órgãos, de ciclo celular e de fragmentação de DNA (ácido desoxirribonucleico). Os tratamentos com NPsel e MHT+NPsel foram eficazes em normalizar as alterações do eritrograma promovidas pelo tumor. Isto provavelmente foi decorrente não só da ação antioxidante do Selol, mas também de sua ação antitumorigênica; esta última, particularmente quando associada ao tratamento com magnetohipertermia. Apesar de os tratamentos com MHT ou NPsel terem reduzido significativamente a percentagem de fragmentação do DNA em relação aos controles negativo e tumor, enquanto para o tratamento combinado MHT+NPsel tal redução foi apenas em relação ao controle negativo, este último tratamento foi mais eficiente em reduzir o volume tumoral. Por meio dos resultados bioquímicos identificou-se ausência de toxicidade dos tratamentos para os órgãos avaliados, corroborando os resultados histopatológicos. Concluindo, o presente estudo evidenciou que o transplante ortotópico forneceu um microambiente crítico para interações celulares envolvidas no desenvolvimento do câncer e metástase subsequente, e proporcionou suporte anatômico para a compreensão do processo de disseminação linfática de células cancerosas. Também demonstrou que, após a terapia proposta, $100 \%$ dos animais ficaram livres de metástase na rede linfonodal e órgãos. Tendo em vista que o Selol possui uma importante atividade antitumoral, este composto conjugado a nanopartículas (NPsel), principalmente quando associado à magnetohipertermia (MHT+NPsel), torna-se uma potencial forma de tratamento para o câncer.

Palavras-chave: modelo ortotópico imunocompetente de câncer animal; tumor sólido de Ehrlich; linfonodo sentinela (LNS); mapeamento linfático; nanopartículas magnéticas; magnetohipertermia; quimioterapia antioxidante; Selol 


\begin{abstract}
Breast cancer remains the most common cause of cancer deaths among women worldwide, regardless of the emergence and evolution of new therapeutic approaches. Thus, to understand the fundamental mechanisms behind malignancy and also contribute to the discovery of improved methods for prevention, diagnosis and treatment, animal cancer models remain essential. This work focused on breast cancer and was developed in two stages. In the first stage, the objective was to establish an ideal orthotopic model of breast cancer in Swiss mice, with anatomic characterization and computed microtomography (CMT), histopathological research for involvement of micrometástases, lymphatic mapping and interleukin expression. In terms of results, a detectable tumor was observed 24 hours after inoculation of fresh cells of Ehrlich tumor and, after 7 days of incubation, breast, lymphatic, muscular and vascular dermal invasion was seen, as well as micrometastasis in breast adipose tissue, sentinel lymph node (SLN) and contralateral lymph nodes. Levels of pro-inflammatory Th1 cytokines (IL-IL1 $\beta$ and 17) were significantly higher than levels of anti-inflammatory Th2 cytokine (IL-4) after inoculation of fresh tumor cells. In contrast, frozen tumor cells induced tumor development only 14 days after the inoculation, while presenting expression of distinct interleukins. In the second stage of this work, the goal was to use this orthotopic model to test a new therapeutic approach, using two combination therapies, magnetohyperthermia (MHT) and antioxidant chemotherapy, both based on nanostructured materials. For this, $1.6 \times 10^{6}$ fresh Ehrlich tumor cells $(100 \mu \mathrm{L})$ were inoculated in the right fifth mammary gland. After 24 hours and with tumor already implanted, the treatments proceeded via intratumoral: (1) inoculation of $110 \mu \mathrm{L}$ of magnetic nanoparticles coated with citrate (NPcit) at a concentration of $18 \times 10^{18}$ partículas/mL, followed by MHT, carrie out in equipment operating at $1 \mathrm{MHz}$ and 40 Oe field amplitude; (2) inoculation of $100 \mu \mathrm{L}$ nanocapsules PLGA containing $10 \mathrm{mg} /$ ml Selol 5\% (NPsel); 3) combination therapy with MHT+NPsel. Negative control (healthy animals) received $100 \mu \mathrm{L}$ saline intraperitoneally; the positive control received Paclitaxel $(16 \mathrm{mg} / \mathrm{kg})$ in a single intraperitoneal injection $(50 \mu \mathrm{L}) 24$ hours after the tumor inoculation; and tumor control received no treatment. To evaluate the efficacy of the treatments in containing tumor growth, the tumor weight and volume were assessed, and histopathological evaluations were made of the inoculated breast cancer, contralateral breast, SLN and contralateral lymph node. To evaluate the possible
\end{abstract}


toxicity of treatments, in addition to the clinical evaluation of the animals and survival rate, a hematological, biochemical and histological analysis was performed for organs, cell cycle and DNA fragmentation. Treatments with NPsel and MHT+NPsel were effective in normalizing the erythrogram changes introduced by the tumor. This was probably due not only to the antioxidant action of Selol, but also its antitumorigenic action, particularly when associated with magnetohyperthermia. Treatments with MHT and NPsel significantly reduced the percentage of DNA fragmentation compared to negative and tumor controls, while for the combined MHT+NPsel treatment the reduction was only noticeable when compared to the negative control. However, the latter treatment was more effective in reducing tumor volume. Biochemical results suggested absence of toxicity of the treatments for the evaluated organs, confirming the histopathological findings. In conclusion, this study showed that orthotopic transplantation provided a critical microenvironment for cellular interactions involved in cancer development and subsequent metastasis, and provided anatomic support for the understanding of the process of lymphatic dissemination of cancer cells. It also demonstrated that after the proposed therapy, $100 \%$ of the animals were free of metastasis in lymph node and organ network. Considering that Selol has a significant antitumor activity, this compound conjugated to nanoparticles (NPsel), especially when associated with magnetohyperthermia (MHT+NPsel), has become a potential form of treatment for cancer.

Keywords: orthotopic animal model immunocompetent cancer; Ehrlich solid tumor; Sentinel lymph node (SLN); lymphatic mapping; magnetic nanoparticles; magnetohyperthermia; antioxidant chemotherapy; Selol. 
Este trabalho está apresentado em duas etapas. A primeira aborda o estabelecimento e caracterização de um modelo otimizado de câncer de mama ortotópico. A segunda etapa aborda o uso desse novo modelo ortotópico de câncer de mama para uma nova abordagem terapêutica, magnetohipertremia e quimioterapia antitumoral. 


\section{ETAPA 1: CARACTERIZAÇÃO ORTOTÓPICA DO TUMOR DE EHRLICH, MAPEAMENTO LINFÁTICO, INVESTIGAÇÃO HISTOPATOLÓGICA DE ACOMETIMENTO DE MICROMETÁSTASES，E EXPRESSÃO DE INTERLEUCINAS EM CAMUNDONGOS SWISS}

\section{INTRODUÇÃO}

\section{CÂNCER}

Câncer é a designação dada ao conjunto de manifestações patológicas caracterizadas pela perda de controle da proliferação celular e ganho da capacidade de invadir tecidos adjacentes ou sofrer metástases para tecidos distantes (RIBEIRO et al., 2003). É assinalado por uma sequência de alterações genéticas que conferem à célula a propriedade de evasão dos mecanismos de controles homeostáticos, garantindo assim a sua própria sobrevivência e proliferação. Essas mutações genéticas levam ao surgimento de células anormais, incompatíveis com as funções celulares relacionadas à organização estrutural e fisiológica. Esse fenômeno é desenvolvido por processo de múltiplos passos, tornando-a uma doença altamente complexa (WEINBERG, 2002; WEINBERG, 2015).

O câncer é uma doença crônico-degenerativa com grande incidência e distribuição geográfica, que acarreta impacto negativo na saúde pública mundial (INCA, 2014), por apresentar desafios físicos, socioeconômicos e psicológicos aos indivíduos diagnosticados, assim como por interferir negativamente na sua qualidade de vida. Considerado um sério problema de saúde em países desenvolvidos e em desenvolvimento, consiste em importante causa de morte no Brasil e no mundo (PARISOTTO, 2010). Projeções das mortes por câncer em todo o mundo mostram seu crescimento contínuo, com uma estimativa de 17 milhões do número de óbitos (Organização Mundial da Saúde (OMS)), em 2030. A OMS ainda estima 27 milhões de casos incidentes de câncer neste ano e 75 milhões de pessoas vivas apresentando a doença a cada ano, tornando o câncer ainda mais relevante como problema de saúde pública mundial. 
O Instituto Nacional de Câncer José Alencar Gomes da Silva (INCA) estimou cerca de 580 mil casos novos da doença para 2014, sendo $11 \%$ maior que o total de novos casos esperados para os dois anos anteriores. De acordo com a mesma publicação, também havia previsão para 2014 de um risco calculado de 57.12 casos a cada 100 mil mulheres. As estatísticas mostram que no Brasil, os tumores mais frequentes no sexo masculino são os de próstata, pulmão, estômago, cólon, reto e esôfago, enquanto que em mulheres predominam os de pele, mama, seguidos pelos cânceres de colo uterino, cólon e reto, pulmão e estômago (Tabela 1).

A etiologia do câncer é decorrente da combinação de vários fatores, dentre eles os genéticos (predisposição hereditária), ambientais e infecciosos (carcinógenos químicos, físicos, motivados por tabaco, vírus e bactérias), nutricionais (obesidade) e hormonais (PERSSON, 2000).

Tabela 1: Estimativas de novos casos de câncer para o ano de 2014 (taxa bruta de incidência por 100 mil habitantes), segundo sexo e localização primária.

\begin{tabular}{|c|c|c|c|c|c|c|c|}
\hline Localização primária & casos & $\%$ & & & Localização primária & casos & $\%$ \\
\hline Próstata & 68.800 & $22,8 \%$ & Homens & Mulheres & Mama Feminina & 57.120 & $20,8 \%$ \\
\hline Traqueia, Brônquio e Pulmão & 16.400 & $5,4 \%$ & & & Cólon e Reto & 17.530 & $6,4 \%$ \\
\hline Cólon e Reto & 15.070 & $5,0 \%$ & & & Colo do Útero & 15.590 & $5,7 \%$ \\
\hline Estômago & 12.870 & $4,3 \%$ & & & Traqueia, Brônquio e Pulmăo & 10.930 & $4,0 \%$ \\
\hline Cavidade Oral & 11.280 & $3,7 \%$ & & & Glândula Tireoide & 8.050 & $2,9 \%$ \\
\hline Esôfago & 8.010 & $2,6 \%$ & & & Estômago & 7.520 & $2,7 \%$ \\
\hline Laringe & 6.870 & $2,3 \%$ & & & Corpo do Útero & 5.900 & $2,2 \%$ \\
\hline Bexiga & 6.750 & $2,2 \%$ & & & Ovário & 5.680 & $2,1 \%$ \\
\hline Leucemias & 5.050 & $1,7 \%$ & & & Linfoma não Hodgkin & 4.850 & $1,8 \%$ \\
\hline Sistema Nervoso Central & 4.960 & $1,6 \%$ & & & Leucemias & 4.320 & $1,6 \%$ \\
\hline
\end{tabular}

Obs. Incidência estimada para 2014 (INCA) dos dez cânceres com maior ocorrência em ambos os sexos, excluindo-se o câncer de pele não melanoma. Fonte: Instituto Nacional de Câncer José Alencar Gomes da Silva.

O aumento considerável do problema pode estar relacionado ao fato de que o prognóstico do câncer depende, de forma expressiva, do desenvolvimento de novas tecnologias de diagnóstico, da exposição dos indivíduos a fatores de riscos, das alterações demográficas com redução das taxas de mortalidade e natalidade e, consequentemente, do prolongamento da expectativa de vida e do envelhecimento populacional. 
Apesar do câncer ser um dos grandes causadores de óbitos na história da humanidade, comumente é relacionado com as doenças modernas. Não obstante, tem estado sempre presente, existindo indícios da doença nos estudos de paleopatologia em fósseis que remontam a 8.000 antes de Cristo (a.C.), Egito (1.600 a.C.), Babilônia e Grécia. As primeiras descrições de tumores foram aludidas em papiros da Índia (600 a.C.). Mas foi Hipócrates (460 a 370 a.C.) que utilizou pela primeira vez a palavra karkinos ou Carcinus (um colossal caranguejo concernente à mitologia grega), que significa câncer, para designar um tipo de tumor de mama que produzia projeções e vasos (LANDSKRON, 2008).

\section{Metástase}

Intrinsecamente ligada ao câncer, a metástase é uma palavra derivada do grego metastatis, que significa "mudança de local" ou "deslocamento". Refere-se a um processo extremamente complexo que ocorre por meio de uma série de passos sequenciais, os quais incluem a invasão dos tecidos adjacentes, irrupção das células cancerígenas através da membrana basal para vasos sanguíneos ou linfáticos, e transporte por meio do sistema circulatório, extravasamento e crescimento em um órgão secundário. Enquanto a progressão e as etapas para formação do câncer são relativamente bem entendidas, os processos de invasão e metástase ainda precisam ser melhor compreendidos com relação ao câncer de mama. A relevância clínica das metástases é baseada não só na sua associação à letalidade, mas também sobre as suas características biológicas únicas, como as vias de propagação, a latência, a carga tumoral e o sitio metastático (JANDIAL, 2013; WEINBERG et al., 2015).

A metástase tumoral é atribuída não apenas às anormalidades de células cancerígenas, mas também às mudanças induzidas pela interação dessas células com as células de tecidos circundantes. A resposta imunitária do hospedeiro às células cancerígenas pode contribuir para um aumento da incidência de metástases de tumores. Nishikawa (2008) ressalta que a remoção cirúrgica de tecidos tumorais pode provocar a recorrência de tumores e metástases.

Os tumores primários são responsáveis fundamentalmente por apenas $10 \%$ dos óbitos, sendo os $90 \%$ restantes devidos às metástases, ou, em outras palavras, tumores secundários surgidos a partir de populações celulares heterogêneas originadas de um tumor primário (CASTRO et al., 1994; JANDIAL, 2013). Quando essas células têm 
sucesso em fundar colônias em locais distantes, os danos causados são muito grandes (WEINBERG, 2015) e constituem a principal causa de morbidade, mortalidade e falha do tratamento (GIBBS, 2003).

\section{Estadiamento clínico e patológico}

Estadiamento é a classificação da fase em que o câncer se encontra quando detectado e permite categorizar cada tumor. O estadiamento é importante porque as taxas de sobrevida são diferentes quando a doença está restrita ao tumor primário ou quando apresenta metástase. Ele reflete não somente a taxa de crescimento e a extensão da doença, mas também o tipo de tumor e sua interação com o hospedeiro. $O$ estadiamento clínico é definido a partir dos achados dos exames físicos e complementares tais como, laboratoriais e de imagem. Com base nas análises anatomo patológicas da peça operatória, que são estabelecidas após tratamento cirúrgico, o estadiamento patológico pode indicar com maior acurácia a extensão da doença (INCA, 2012). O sistema mais utilizado de estadiamento é o preconizado pela União Internacional Contra o Câncer (UICC), o TNM (Tumor-Nodo-Metástase) de Classificação dos Tumores Malignos (BRASIL, 2012; OMS, 2012).

\section{MAMA HUMANA}

A mama está presente tanto no corpo masculino quanto no feminino. Em ambos os sexos, ela tem a mesma origem embrionária e desenvolvimento pubertário, com variações anatômicas na forma e em tamanho, de acordo com a etnia, idade, sexo e o estado funcional do individuo. Nos homens púberes, a testosterona inibe o crescimento da mama e a reduz a um pequeno disco de tecido glandular. Anatomicamente, apenas a aréola e a papila mamária $(\mathrm{P})$ são comparáveis às da mulher.

Nas mulheres, no entanto, a influência do estrógeno permite o desenvolvimento das mamas, cujo tamanho é aumentado devido, principalmente, à deposição de tecido adiposo. Sua morfologia difere em função da idade, lactação, gestação, obesidade e ciclo menstrual. A mama é formada por um corpo glandular que repousa sobre a parede do tórax (entre a camada profunda da fáscia superficial e a fáscia do músculo peitoral maior, o espaço retromamário) e se encontra no tecido subcutâneo entre a segunda e a 
sexta costela, e entre o externo e a linha axilar média. Externamente, cada mama apresenta, na sua região central, uma aréola e uma papila (protuberância composta de fibras musculares elásticas) (Figura ) (LATARJET e LIARD, 1993; DeVITA, 2008; BRASIL, 2012; ROSS, 2012; BRASIL, 2013).

Em relação à sua constituição, a mama é composta de 15 a 25 lóbulos de glândulas tuboalveolares (Figura 1) (DeVITA, 2008; JUNQUEIRA e CARNEIRO, 2013). O corpo glandular é formado por dois sistemas: o ductal e o lobular. O sistema ductal é composto por ramificações e ácinos (porção terminal da "árvore" mamária, onde estão as células secretoras que produzem o leite), em cujas extremidades estão localizados os lóbulos (conjunto de ácinos), componentes do sistema lobular (unidade de funcionamento formada por um conjunto de lóbulos). Cada unidade lobular é formada por parênquima (alvéolos secretores na glândula mamária em lactação, e ductos terminais, na glândula mamária em repouso). Esses dois sistemas são sustentados por tecidos conjuntivo e adiposo, que possibilitam a passagem dos nervos, vasos sanguíneos e linfáticos.

Os vasos linfáticos da mama drenam a linfa principalmente para os linfonodos das cadeias axilar e mamária interna. $\mathrm{O}$ assoalho muscular é composto prioritariamente pelos músculos peitoral maior, peitoral menor e serrátil anterior, que se relacionam com a face profunda da mama separando-a do gradil costal. Sua topografia está dividida em quadrantes superiores (lateral e medial), inferiores (lateral e medial) e região central. Essa divisão é essencial para a localização e correlação dos achados de exame clínico e de imagem (WERNER, 2002; ROBBINS \& COTRAN, 2009; BRASIL, 2013). 


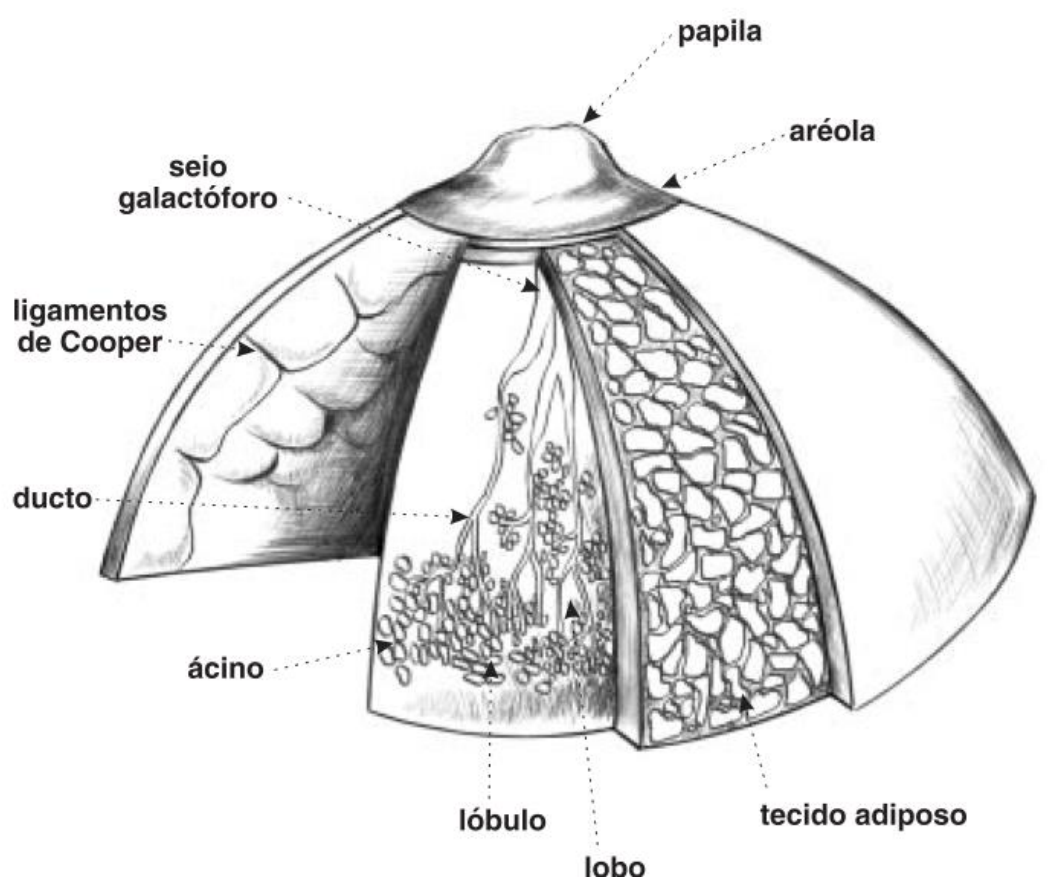

Figura 1: Anatomia da mama humana. Fonte: BRASIL 2002.

\section{Câncer de mama}

Arquivos médicos registram o câncer de mama desde 1.600 a.C em papiros de cinco metros oriundos do antigo Egito, entre os quais estão o papiro de Edwing Smith, procedente de Tebas (Karnak e Luxor) encontrado em 1862, nomeado de Instruções sobre tumores da mama. Esses arquivos apresentam informações acerca das afecções cirúrgicas, tumorações e protocolos cirúrgicos, como o de que para uma mama com tumoração quente ao tato, não havia tratamento. No entanto, os demais tumores eram tratados queimando-se a lesão com fogo ou extirpando-se a mama com instrumentos cortantes. Outros papiros e manuscritos hieroglíficos do século XIX relatavam tipos de cânceres e seus tratamentos, baseados em óleo de rícino, composto de cevada e remoção cirúrgica dos tumores superficiais (NCI, 1998).

O câncer de mama é o segundo tipo de câncer mais frequente no mundo e o mais comum entre as mulheres, representando $23 \%$ de todos os cânceres em mulheres e $14 \%$ das mortes para essa doença (JEMAL et al., 2011; IRVIN, 2011). Na população mundial, a sobrevida média após cinco anos é de $61 \%$, variando de $80 \%$ ou mais na América do Norte, Suécia e Japão, e sendo cerca de 60\% em países de renda média e abaixo de 40\% em países de baixa renda (COLEMAN et al., 2008; INCA, 2012). Tratase de uma doença heterogênea de natureza complexa, que pode se manifestar por meio 
de múltiplas formas de apresentação clínica e histopatológica, bem como por diferenças na pré e pós-menopausa, pelos diferentes graus de agressividade tumoral e pelo potencial metastático (PIRES e DELGADO, 2004; EISENBERG e KAIFMAN, 2001).

De acordo com o INCA, no Brasil, o câncer de mama é o tipo mais frequente nas mulheres, embora varie nas diferentes regiões brasileiras: para cada 100 mil habitantes, nas regiões Sul e Sudeste surgem 71 casos, no Centro-Oeste, 51 casos, no Nordeste, 37 casos e na região Norte, 21 casos (INCA, 2014).

O câncer de mama é considerado uma modalidade de bom prognóstico quando identificado em estágios iniciais e tratado convenientemente. Não obstante, suas taxas de mortalidade continuam elevadas no Brasil, possivelmente porque a doença ainda é diagnosticada em etapas de desenvolvimento avançadas. Sendo assim, o diagnóstico precoce é especialmente importante, pois possibilita terapias mais efetivas, menos agressivas e contribui para a redução do estágio de apresentação da doença (INCA, 2014; BRASIL, 2013; WHO, 2007).

\section{Fatores de risco para o câncer de mama}

Segundo a American Cancer Society (USA, 2013), o fator de risco mais importante para o desenvolvimento de câncer da mama é o gênero. Os homens podem desenvolvê-lo, mas essa neoplasia é cerca de 100 vezes mais comum nas mulheres do que nos homens. Isso decorre, provavelmente, do fato de os homens terem menos hormônios femininos estrogênio (ER) e progesterona, que podem promover o crescimento de células de câncer de mama.

A idade, de acordo com o INCA (2014), ainda é um fator preponderante para o risco de câncer de mama. A ocorrência aumenta significativamente na faixa etária dos 50 anos e, em seguida, declina lentamente. Todavia, a literatura fundamenta que fatores relacionados à vida reprodutiva da mulher, tais como menarca precoce, nuliparidade, primeira gestação acima dos 30 anos, menopausa tardia, uso prolongado de anticoncepcional, entre outros, também trazem riscos. A obesidade, a grande ingestão de gordura animal, o sedentarismo, o tabagismo e a reposição hormonal são outros fatores que podem aumentar as chances de se desenvolver câncer de mama. Além desses, a exposição à radiação ionizante, mesmo em baixas doses, também é considerada um fator de risco, particularmente durante a puberdade (CARVALHO, 
2005; INCA, 2012). A American Cancer Society (EUA, 2013) acrescenta ainda entre os riscos de câncer de mama os fatores genéticos, os quais contribuem com cerca de $5 \%$ a $10 \%$, principalmente ao envolver mutações nos genes breast cancer 1 (BRCA1) e breast cancer 2 (BRCA2), história familiar, história pessoal de câncer de mama, raça, etnia e tecido mamário denso.

O Ministério da Saúde (BRASIL, 2013) considera com alto risco para o desenvolvimento de câncer de mama aquela mulher cujo histórico familiar apresenta pelo menos um ascendente ou parente direto (mãe ou irmã), abaixo dos 50 anos de idade, com diagnóstico de câncer de mama ou em qualquer faixa etária, com diagnóstico de câncer de mama bilateral ou câncer de ovário. Inclui-se, ainda, nesse grupo de alto risco, aquela que teve diagnóstico prévio de hiperplasia atípica ou neoplasia lobular in situ.

\section{Classificação dos cânceres de mama}

Existem vários tipos de cânceres de mama. Alguns deles são bastante raros, como por exemplo, o metaplásico, um subtipo responsável por menos de $1 \%$ de todos os cânceres de mama. Outro raro é a Doença de Paget, um tumor que causa prurido no complexo areolopapilar e espessamento cutâneo, evoluindo para erosão eczematoide ou exudativa, e que, em 97\% dos casos, apresenta carcinoma subjacente. Esse tumor representa de 0,5\% a $4 \%$ dos cânceres de mama. Em alguns casos, o tumor pode ser formado por uma combinação desses tipos de câncer ou por uma mistura de câncer de mama invasivo e câncer de mama in situ, segundo dados da American Cancer Society (TZU-CHIEH, 1999; TAVASSOLI, 1992; LUINI, 2007; USA, 2013). Outros tipos de cânceres de mama são apresentados a seguir.

\section{Carcinoma ductal in situ}

O carcinoma ductal in situ (Figura 2), ou carcinoma intraductal, é uma proliferação epitelial neoplásica que se limita aos ductos, ou lóbulos, pela membrana basal. As células mioepiteliais são preservadas, contudo o seu número é mais reduzido. São classificados de baixo e alto grau, levando-se em consideração o volume nuclear, a distribuição da cromatina e as características dos nucléolos. Tal classificação representa o grau de agressividade da lesão (BRASIL, 2012; ROBBINS \& COTRAN, 2009; USA, 2013; BRASIL, 2013). 


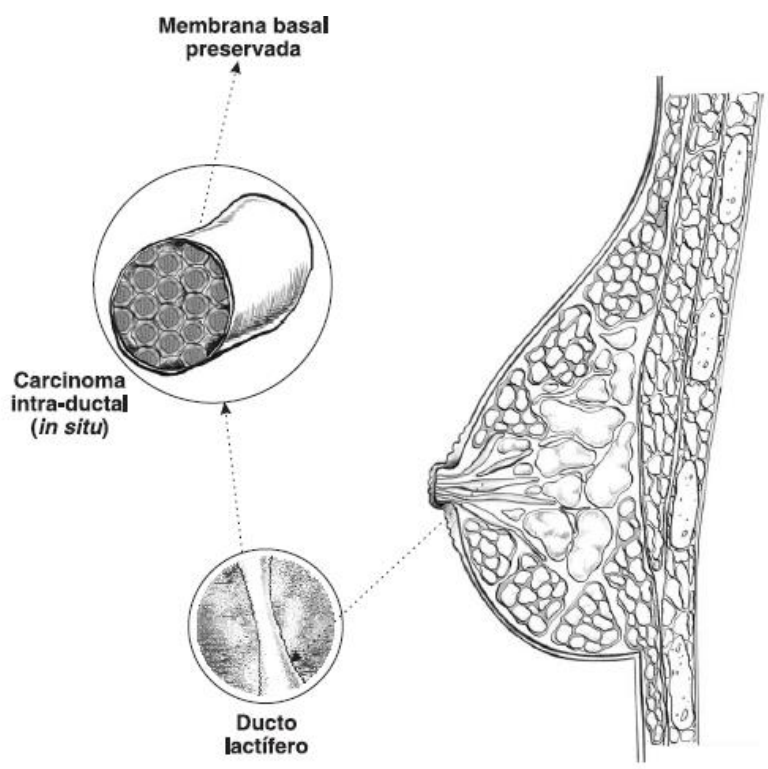

Figura 2: Carcinoma mamário humano: Carcinoma in situ, fonte, BRASIL 2002

\section{Carcinoma invasivo}

O Carcinoma invasivo é um grupo heterogêneo de tumores epiteliais que infiltram a membrana basal da unidade ductubular terminal e invadem o estroma com potencialidade de formação de metástase. O tipo de carcinoma invasivo mais prevalente é o ductal infiltrante, com vários subtipos histopatológicos relacionados a um melhor prognóstico, como os medulares, os mucinosos e os tubulares. (BRASIL, 2013; USA, 2013).

\section{Metástase de câncer de mama}

Em relação ao câncer de mama, 20\% a 30\% dos indivíduos diagnosticados apresentam metástases, que ordinariamente ocorrem nos ossos, pulmões, fígado e cérebro, fato que pode sinalizar a entrada da doença na sua fase incurável (DEIL, 2000; COLEMAN, 2002). Para o câncer de mama, alguns fatores clínicos e patológicos são comumente associados para avaliar o risco de desenvolvimento de metástases, dentre eles, a idade do paciente, o estágio de apresentação da doença, o tamanho do tumor e a 
invasão linfática (ALANKO, 1985; WEIGELT et al, 2005; EBCTCG, 2005; WHO, 2007; CHIA, 2008; BRASIL, 2013; INCA, 2014).

\section{Linfonodo sentinela}

O comprometimento metastático dos linfonodos axilares é um importante fator prognóstico em câncer de mama. O linfonodo sentinela (LNS) é o primeiro linfonodo para o qual ocorre drenagem linfática oriunda do tumor primário e é representativo para toda rede nodal. As metástases para os LNS não são casuais, mas decorrem da progressão sequencial e preferencial de células pelo sistema linfático (FISHER et al, 1983; PITORRE et al, 2015). Nas análises histopatológicas os agregados celulares com extensão entre 0,2 e $2 \mathrm{~mm}$ em LNS, são denominadas metástases ocultas ou micrometástase, e são interpretadas como foco metastático (SOBIN; WITTEKIND 2002).

Os linfonodos axilares são os sítios preferenciais de disseminação do câncer da mama. O estádio axilar é considerado o principal fator de prognóstico, promovendo com acurácia a identificação de micrometástases quando essas ainda não podem ser detectadas por exames de imagem. Além de fator importante na avaliação do prognóstico, também influencia nas decisões sobre o tratamento da doença (FISHER et al., 1983; MORTON et al, 1992; SHIN et al, 2004; ESSNER, 2006; QUADROS, 2007; PINHEIRO et al, 2014; PODGRABINSKA, 2014; PITORRE et al, 2015).

\section{MODELOS ANIMAIS}

A compreensão dos processos fisiopatológicos básicos de desenvolvimento do câncer, testar potenciais agentes preventivos, curativos e investigar os processos do impacto da intervenção demandam o uso de modelos animais (CHOW et al, 2008; MEDINA, 2010). Os camundongos são os animais mais utilizados em estudos científicos, especialmente na pesquisa biomédica e em ensaios biológicos. A opção por esses animais advém principalmente do tamanho reduzido, fácil manuseio, adaptabilidade, prolificidade, docilidade e sociabilidade que possuem (WORKMAN et al., 2010; NIH, 2013; FCF-IQ/USP, 2013). 
O uso intensivo desse modelo possibilitou o surgimento de inúmeras linhagens específicas, como: (1) Swiss, para fins de estudos com propósitos dos mais variados, como o entendimento de doenças metabólicas, autoimunes, fixação de complemento, tumores de mama e pulmão; (2) BALB/c, classificados com INBRED albinos e dotados de genótipo A/A TYRP $1{ }^{\mathrm{B}} / \mathrm{TYRP}^{\mathrm{B}}{ }^{\mathrm{TY}} \mathrm{R}^{\mathrm{C}} / \mathrm{TYR}^{\mathrm{C}}$; (3) 129P3/J, apropriados para estudos de células tronco embrionárias; (4) A/HEJ, amplamente utilizados em câncer e pesquisa de imunologia; (5) AKR/J, utilizados na investigação do câncer e na imunologia, como uma fonte de antígeno Thy1 e (6) AKR e AKR/J, que expressam o retrovírus ectópico AKV em todos os tecidos (JACKSON, 2015). A Genética tem tido papel fundamental na obtenção destes modelos, por meio da produção de animais geneticamente modificados. Atualmente existem cerca de 10 mil linhagens de camundongos utilizadas como modelo para estudo das mais diversas doenças humanas (CHORILLI et al, 2007; USP, 2013).

\section{Anatomia das glândulas mamárias de ratas}

Os estudos dos mecanismos patológicos são facilitados pelo conhecimento detalhado da anatomofisiologia das estruturas do modelo animal proposto. Em ratas, espécie mais próxima dos camundongos, do ponto de vista de lactação, as glândulas mamárias têm como função precípua a secreção de leite para nutrição da prole e estão dispostas em número variável em duas linhas simétricas no tecido subcutâneo, alinhadas no plano sagital em uma posição ventrolateral, da região cervical até a região inguinal, cada uma com sua papila mamária (ZHAO et al., 1998; MASSO-WELCH et al., 2000).

Depois de completamente maturadas, as glândulas mamárias são constituídas por: um par de glândulas cervicais que se estendem cranialmente para as glândulas submandibulares e parótida e, lateralmente, até a zona média do membro anterior; dois pares de glândulas torácicas que, atingindo a zona interescapular, estendem-se lateral e dorsalmente a partir da papila mamária que se situa na zona média; um par de glândulas abdominais e dois pares de glândulas inguinais que se expandem sequencial e medialmente para a região púbica, caudalmente para a região perianal e lateralmente para a zona média dos membros inferiores. São visíveis externamente somente as papilas mamárias ligadas internamente a um ou dois ductos mamários principais, os quais permitem a liberação de leite durante a lactação. Intrinsecamente, as papilas 
estendem-se no subcutâneo dorsolateralmente, como folhetos fibro-adiposos (RUSSO e RUSSO, 1996; COVELLI, 2009).

A mama é formada por um sistema de lóbulos e ductos excretores e composto por parênquima e estroma que invadem o coxim adiposo. O sistema tubular ou ductal é formado por dois tipos celulares organizados em camadas: uma mais interna de células epiteliais que revestem todo o lúmen e uma outra de células mioepiteliais, mais externa e descontínua, que se apoiam na membrana basal. Antes do nascimento, há invasão do coxim adiposo por uma estrutura ductal rudimentar. Essa estrutura epitelial permanece em repouso, aproximadamente até três semanas de idade (RICHERT et al., 2000).

\section{Distribuição e nomenclatura dos linfonodos}

Como mencionado, o sistema linfático é de grande importância no desenvolvimento do câncer, merecendo, portanto, atenção especial nos estudos que empregam os modelos animais. A literatura não registra estudos dos linfonodos em camundongos Swiss, espécie a ser usada neste trabalho. No entanto, Kawashima e

colaboradores (1964) e Van den Broeck, Derore e Simoens (2006) descreveram a topografia e a nomenclatura de 22 linfonodos de camundongos, encontrados nas regiões: periférica (cabeça, pescoço, membros anteriores e membros posteriores), intratorácica e intra-abdominal.

Os linfonodos periféricos são denominados mandibulares e mandibulares acessórios, parótidos superficiais, cervicais profundos craniais, axilares, axilares acessórios. Na região dos membros anteriores estão os linfonodos subiliacos, esquiáticos e poplíteos. Na região atorácica encontra-se linfonodos mediastino cranial; traqueobraquial e mediastino caudal. Na região intra-abdominal constam dois grupos de linfonodos que estão associados ao trato gastrointestinal e os situados ao longo das principais artérias abdominais: linfonodos; gástricos; pancreaticoduodenais, jejunais; cólicos; mesentéricos caudais; renais; lombares aórticos (ocorrência inconstante); ilíacos laterais (ocorrência inconstante); ilíacos mediais e ilíacos externos (Figura 3).

O tratamento cirúrgico do câncer de mama evoluiu da mastectomia radical à cirurgia conservadora da mama. Da mesma forma, o tratamento cirúrgico dos linfonodos regionais também se tornou menos invasivo. O mapeamento linfático corroborou para esta evolução e, para a identificação da rede linfática concomitantemente com LNS também é utilizada, entre outras técnicas, a coloração 
com corantes vitais, substâncias tintoriais utilizadas para coloração de células ou tecidos vivos (PETREK, 1998; MANSEL, 2006).
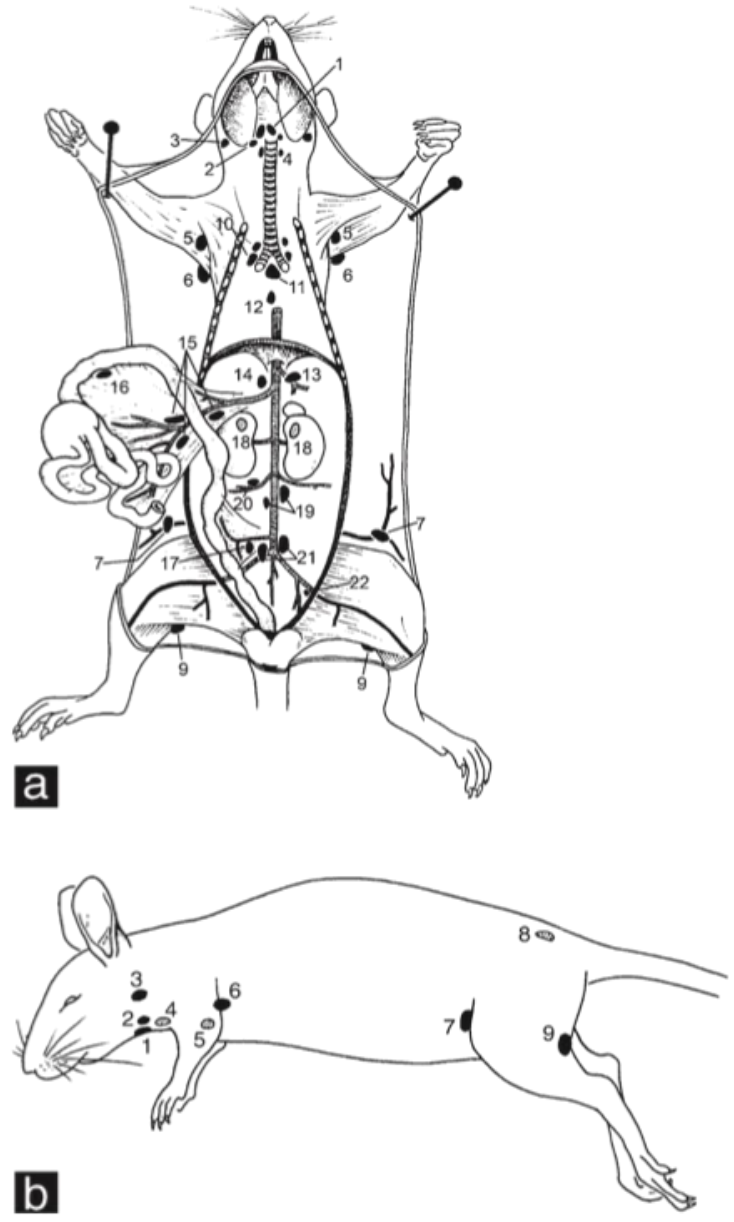

Figura 1: Desenho esquemático da localização dos gânglios linfáticos de camundongos BALB/cAnNCrl. (A) ventral e (B) vista lateral. Os números referem-se aos linfonodos: 1 mandibular; 2 mandibular acessório; 3 parótida superficial; 4 craniocervical profundo; 5 próprio axilar; 6 axilar acessório, 7 subiliaco; 8 ciático, 9 popliteal; 10 cranial mediastinal; 11 traqueobronquial; 12 caudal mediastinal; 13 gástrico;14 pancreático duodenal; 15 jejunal; 16 cólico; 17 caudal mesentérico; 18 renal; 19 lombar aórtico; 20 ilíaco lateral; 21 ilíaco medial 222 ilíaco externo. Fonte: Van den Broeck, Derore e Simoens, 2006.

\section{TUMOR DE EHRLICH}

Para fins didático-científicos da biologia tumoral e para pesquisas na melhoria do diagnóstico e nas estratégias terapêuticas para tumores, uma grande variedade de modelos tumorais foi estabelecida. Dentre eles, citam-se os tumores ascítico e sólido de Ehrlich (GUERRA, 1983), tumor de Walker (MORAES et al., 2000), melanoma (B16 e 
F10) (ALTERMAN et al., 1985) e tumor de cólon (MC38, MC32a e CT26) (WAINSTEIN, 2001).

Estudos intensivos sobre os tumores transplantáveis foram realizados nas últimas três décadas. O Tumor de Ehrlich (TE) é um dos mais comuns. Apareceu, inicialmente, como câncer de mama espontâneo em fêmeas de camundongos e foi usado por Ehrlich e Apolant (1905) como um tumor experimental, sendo transplantado de tecidos tumorais por via subcutânea de camundongo para camundongo (AKTAŞ, 1996; TAŞKIN, 2002). Em 1932, Loewenthal e Jahn (1932) obtiveram o TE sob a forma de líquido no peritônio, nomeando-o de "Carcinoma Ascítico de Ehrlich", devido à presença de líquido ascítico junto das células de carcinoma. Posteriormente, Lettre e colaboradores (1972) proporcionaram não só o isolamento desse tumor, mas também a conversão do mesmo para um sistema de modelo experimental adequado para pesquisas qualitativa e quantitativa do câncer.

Numerosos pesquisadores, entre eles Paul Ehrlich (1906), têm estudado a evolução tumoral do TE (DAGLI, 1989). A transplantabilidade foi imperiosa para elucidação dos mecanismos pelos quais as neoplasias se instalam no organismo. $\mathrm{O}$ tumor de Ehrlich é constituído por células de origem epitelial e glandular e, portanto, um adenocarcinoma (EHRLICH, 1906; JUBB e KENNEDY, 1993). Sendo uma neoplasia experimental transplantável, pode ser mantido por inoculações sucessivas (passagens ou repiques para hospedeiros) no tecido subcutâneo ou na cavidade peritoneal de camundongos, desenvolvendo-se na forma sólida e na forma ascítica, respectivamente. Ainda no que concerne à caracterização, o TE tem origem epitelial maligna, espécie-específica e corresponde ao adenocarcinoma mamário murino espontâneo. Histologicamente, apresenta grandes áreas necróticas em decorrência da morte (SADEGHIANI, 2008).

Esse tumor vem sendo utilizado como modelo experimental para várias pesquisas, incluindo: vigência de tratamento estrogênico e atividade imunológica (BAIOCHI et al., 1986); eficiência antitumoral na terapia fotodinâmica (BICALHO et al, 2012) e hipertermia (CHEKULAYEVA et al., 2004); estudos dos efeitos adversos graves do metotrexato na quimioterapia do câncer; atividade antineoplásica da bistirosina diaquaníquel (II) (KHANAM et al., 2008; ELMORSI, 2012); avaliação do crescimento tumoral sob o efeito de toxinas, extrato total e polissacarídeos isolados do cogumelo brasileiro Agaricus Blazei Murrill (ABM) (MADY, 2002; JUNIOR et al., 2007); ação de extratos vegetais (BREHMER, 2005; NASCIMENTO et al., 2005, 
2006); determinação de níveis enzimáticos e não enzimáticos em linfomas (SAROJA et al., 2012); inibição tumoral pelo compostos orgânicos isionatos ativos do amendoim (MOOS et al., 1971), disseminação linfática (DAGLI, 1989) e em estudos da eficiência da magnetohipertermia (PORTILHO et al., 2011; SADEGHIANI, 2008), entre outros.

As vantagens da utilização de neoplasias transplantáveis em comparação às demais advém do crescimento prévio, da quantidade e das características iniciais das células tumorais a serem inoculadas e do desenvolvimento rápido da neoplasia, o que restringe o tempo de estudo (da SILVA et al., 2004). Devido à facilidade de seu cultivo e transferência in vivo, a vasta bibliografia disponível (VILELA, 2009), suas características didáticas para o entendimento do comportamento dos tumores malignos e facilidade de manuseio experimental, o tumor de Ehrlich tem sido intensamente aplicado na chamada Oncologia Experimental (OZASLAN et al., 2011).

\section{Transplante tumoral e inoculação ortotópica do tumor de Ehrlich}

A inoculação de células tumorais pode ser classificada em ortotópica e ectópica. A primeira caracteriza-se pela inoculação de células tumorais ou fragmentos delas no sítio anatômico onde o tumor se originou (KUBOTA, 1994), por exemplo, no caso do tumor de Ehrlich, a glândula mamária. Esse modelo, apesar de complexo, tem a vantagem de favorecer as interações com as células do local de implante, tendo em vista que o microambiente desempenha papel crucial no desenvolvimento de células tumorais, além de favorecer a interpretação das informações do comportamento do seu microambiente e respostas dos sistemas imune, sanguíneo, endócrino e fatores de crescimento (PAGET, 1989). Já o segundo tipo, a ectópica, é baseada na inoculação de células tumorais em sítio anatômico diferente do tumor original. Assim, a inoculação do TE por via ectópica ocorre tanto na cavidade peritoneal, para aquisição do tumor na forma ascítica, como por vias subcutânea, intradérmica ou intramuscular, na cabeça, região femoral, língua e coxim plantar, entre outros sítios, para a aquisição da forma sólida (SHARMA, 2010). Quando a inoculação de células tumorais é realizada em animais da mesma linhagem genética, denomina-se inoculação ortotópica homóloga e, quando em linhagens genéticas diferentes, inoculação ortotópica heterológa. Ainda existe a possibilidade da xenotranspalntação, que se refere ao transplante de órgãos vivos, tecidos e/ou células de animais geneticamente modificados, ou não, entre espécies diferentes (BUENO et al., 1996; LIMA et al., 1997; DOOLDENIYA e WARRENS, 2003; RAMOS, 2007; WORKMAN, 2010). 
O grupo de Nanobiotecnologia da Universidade de Brasília (UnB) desenvolveu, em estudos anteriores, pesquisas sobre modelos e vias de inoculações ectópicas do TE nas formas sólida e ascítica em camundongos da linhagem Swiss, tanto por via subcutânea na região posterior lombar (SADEGHIANI, 2008), como no sítio anatômico entre as orelhas (via subcutânea) e na orelha (via intradérmica) (PORTILHO et al., 2011) e intraperitoneal (Ip) na forma ascítica (BARBOSA, 2008). Transplantes ortotópicos com o TE não foram anteriormente realizados, embora, deva ser citado que o grupo realizou transplante ortotópico na glândula mamária de camundongo da linhagem Balb/c, inoculando células do carcinoma mamário 4T1 (CARNEIRO, 2011). 


\section{JUSTIFICATIVA}

Os aspectos (1) alta incidência do câncer de mama, (2) demanda por modelos animais que possibilitem tanto o estudo da biologia do câncer, quanto a avaliação de intervenções terapêuticas, diagnósticas e do impacto dessa intervenção, (3) a facilidade de cultivo do tumor de Ehrlich (TE) que, além de ter vasta bibliografia disponível, é um tumor equiparável a tumores humanos, (4) a excelência do camundongo da linhagem Swiss, como modelo animal, favorecido por apresentar similaridade genética a humanos, (5) inexistência de modelo de inoculação ortotópica de células do TE em camundongos Swiss que possibilitaria estudos com maior acurácia em relação aos tumores mamários de origem espontânea, (6) a factibilidade em desenvolver estudos da microanatomia da mama e descrever a rede nodular nesse modelo animal, entre outros, justificam a realização desta pesquisa. 


\section{OBJETIVOS GERAIS}

Estabelecer e caracterizar um modelo otimizado de câncer mamário em camundongos, empregando células de Ehrlich e inoculação ortotópica.

\section{Objetivos específicos}

- Descrever a rede ductal em camundongos;

- Realizar mapeamento linfático e detectar linfonodo sentinela;

- Inocular o tumor de Ehrlich (TE) inoculado por via ortotópica;

- Caracterizar o TE por análise clínica, histopatológica e por imagens: microtomografia computadorizada (MCT) e ecografia;

- Investigar acometimento de micrometástase em linfonodos;

- Investigar expressão de citocinas relevantes para o tumor. 


\section{MATERIAL E MÉTODOS}

\section{Animais}

Foram utilizados camundongos fêmeas não isogênicos da linhagem Swiss, virgens ou lactantes no vigésimo quinto dia de lactação, de 3 a 4 meses de vida e massa corporal de 4, adquiridos do Centro Multidisciplinar para Investigação Biológica na Área da Ciência em Animal de Laboratório (CEMIB), da Universidade Estadual de Campinas (Unicamp, SP, Brasil). Os animais foram alojados em caixas plásticas, sob condições controladas de ciclo claro-escuro de 12 horas e temperatura de $22^{\circ} \mathrm{C} \pm 2^{\circ} \mathrm{C}$, recebendo água e ração comercial balanceada Ad Libitum. As caixas foram mantidas no alojamento de animais do Departamento de Genética e Morfologia (GEM) do Instituto de Ciências Biológicas (IB) da Universidade de Brasília (UnB). O projeto foi aprovado pelo Comitê de Ética de Pesquisa em Animais do Instituto de Ciências Biológicas da UnB, UnB.DOC 44783/2013 (Anexos 1 e 2).

\section{Microanatomia Mamária de Camundongos Swiss}

Para o estudo da caracterização, descrição e ilustração científica da distribuição da rede ductal de camundongo fêmea Swiss, foram utilizadas técnicas de coloração, fixação e diafanização adaptadas (anexos 03, 04 e 05) previamente descritas (KRAUSE et al, 2013; DE ASSIS, 2010), necessárias porque o tecido mamário e a pele não tratados apresentam pouca diferenciação óptica. Entre outras, as modificações foram o uso in situ de Azul de Tripan, Azul de Toluidina ou Azul de Tripan e Azul de Toluidina juntos, para coloração dos tecidos.

Para isso, anteriormente empregou-se anestesia por via intraperitoneal, utilizando-se de agulhas com $8 \mathrm{~mm}$ de comprimento e $0,30 \mathrm{~mm}$ de espessura e calibre 30-gauge short, com uma solução contendo cloridrato Ketamina (80 mg/kg) e Xilazina (10 mg/kg) em água destilada. O cloridrato de ketamina (Dopalen) $100 \mathrm{mg} / \mathrm{mL}$ foi obtido de Ceva Saúde Animal Ltda (São Paulo, Brasil), enquanto o cloridrato de xilazina (Coopazine®) $20 \mathrm{mg} / \mathrm{mL}$, da Coopers (São Paulo, Brasil). Seguidamente após efeito anestésico, foram inoculados $50 \mu \mathrm{L}$ das soluções corantes (Azul de Tripan) diretamente no ducto mamário principal da quinta glândula mamária direita e esquerda (Figura 4). Em seguida da eutanásia, os tecidos mamários foram excisados, 
desengordurados, desidratados, diafanizados e reidratados sequencialmente (Anexo 3, 4 e 5).

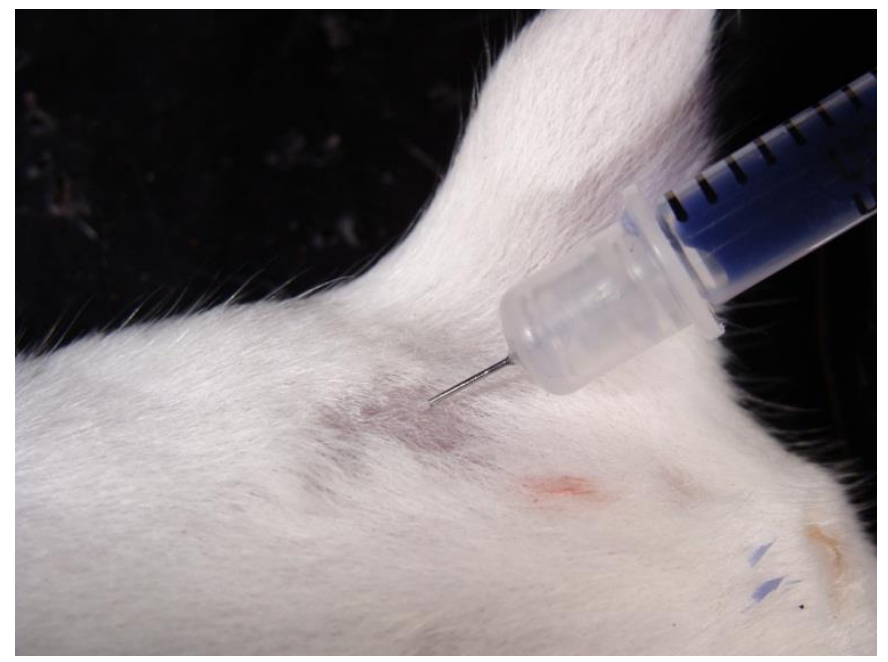

Figura 2: A foto ilustra o procedimento de inoculação do corante Azul de Tripan na quinta glândula mamária esquerda em um camundongo Swiss fêmea.

\section{Microdissecção Mamária em Camundongos Swiss}

Para melhor visualização e descrição das glândulas mamárias e ramificações ductais, foi empregada a técnica de microdissecção em cinco camundongos Swiss fêmeas de 55 dias virgens e dois animais lactantes no vigésimo quinto dia de lactação.

Após a anestesia, os animais foram acomodados em bandeja de dissecção em decúbito dorsal. As glândulas mamárias foram, então, inoculadas via ductos lactíferos principais com $90 \mu \mathrm{L}$ de Azul de Tripan a $2 \%$ e eutanasiados. A seguir, os animais foram imersos em solução salina $0,9 \%$ e fixados em decúbito ventral para dissecação por meio de técnicas de microcirurgia adaptadas, incisões, debridamentos, exérese, diérese e hemostasia, entre outras, sob microscópio estereoscópio. Imagens digitais foram capturadas com câmera SONY S10. Imediatamente após esses procedimentos, foi feito o processamento dos tecidos excisados, conforme descrito nos anexos 3 , 4 e 5 .

\section{Mapeamento Linfático}

Para o procedimento do mapeamento, identificação e denominação dos linfonodos (LN) (Kawashima (1964); Filho e cols. (2003); Van Den Broeck e cols. (2006); Pitorre e cols (2015), empregaram o corante vital (CV) Azul de Tripan, 
assumindo que em sua biodistribuição promoveria a coloração dos vasos e linfonodos e simularia a rota das células neoplásicas do tumor primário até a região nodal.

A administração do corante vital $(20 \mu \mathrm{L})$, baseada nos métodos descritos por Pinheiro e cols. (2003), Kim e cols. (2004), Matthes e cols. (2010), Peleja e cols. (2013), Pitorre e cols. (2015), com modificações, foi feita, por via subcutânea, na região subpapilar no coxim adiposo (subcutâneo das papilas mamárias), na $5^{\text {a }}$ glândula mamária direita e na $4^{\mathrm{a}}$ glândula mamária esquerda, 24 horas antes da eutanásia. Para o referido mapeamento foram utilizados dez animais Swiss, virgens, com 4 meses de vida e massa corporal de $25 \pm 5 \mathrm{~g}$.

\section{Caracterização da inoculação ortotópica}

Esta etapa (1) do estudo foi referente à caracterização da inoculação ortotópica na papila da quinta glândula mamária direita. O tamanho amostral foi baseado levando-se em consideração a proposta de Gontijo e Tice (2003): 6 a 10 animais por grupo para não invalidar o experimento, caso algum animal adoeça ou vá a óbito, sendo que, nos experimentos em que as chances de doença ou de óbito são menores, foram utilizados 5 animais por grupo. Os animais foram distribuídos randomicamente em 6 grupos experimentais, conforme a figura 5 e foram submetidos à inoculação ortotópica de $100 \mu \mathrm{L}$ de células TE frescas ou $100 \mu \mathrm{L}$ de células TE congeladas em freezer $-75^{\circ} \mathrm{C}$ por 30 dias (LETTRE et al., 1972).

Para realizar a caracterização, evolução e o perfil proliferativo do tumor, os testes foram realizados 1, 2, 7, 14 e 21 dias após a inoculação das células tumorais, usando-se as técnicas e imagens de microtomografia computadorizada (MCT), ecografia, análise histopatológica, microdissecção, coloração vital, além de caracterização clínica. Além destas, hemograma, análise bioquímica e dosagem de proteínas e interleucinas foram realizadas para avaliação de possíveis alterações biológicas decorrentes da inoculação ortotópica. 


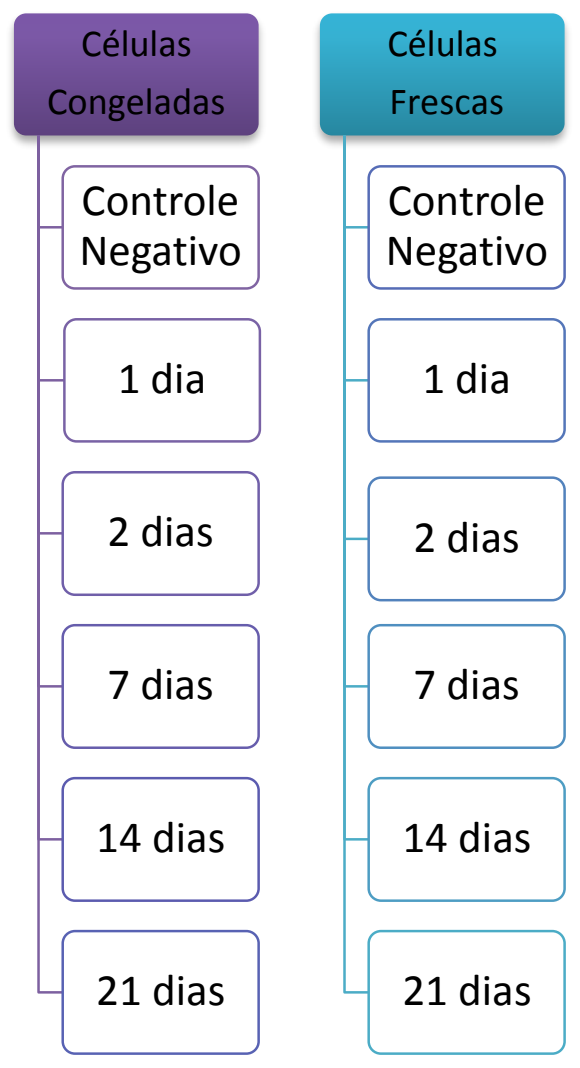

Figura 3: Grupos de inoculação ortotópica $(\mathrm{n}=5)$, células TE frescas e congeladas.

\section{Obtenção das células tumorais}

A partir de alíquotas congeladas em nitrogênio líquido, o tumor ascítico de Ehrlich (TAE) foi mantido por repiques (passagens) semanais em camundongos (hospedeiros), por meio da inoculação de $100 \mu \mathrm{L}$ e $1 \times 10^{6}$ de células de ascite por via intraperitoneal (Ip). Em seguida as células foram congeladas em freezer $-75^{\circ} \mathrm{C}$ por 30 dias. Os inóculos foram obtidos por punção intraperitoneal de animais portando a neoplasia. A viabilidade das células do TE frescas e congeladas foi determinada por meio de coloração com Azul de Tripan 0,2\%, sendo o número de células $/ \mathrm{mL}$ determinado por leitura na câmera de Neubauer. Suspensões celulares com viabilidade superior a $95 \%$ para células frescas e de $68 \%$ para células congeladas foram utilizadas, sendo a concentração dos inóculos ajustada com tampão fosfato-salina (Phosphate Buffered Saline, PBS) estéril.

\section{Inoculação ortotópica}

A agulha (figura 6A) utilizada para inoculação ortotópica foi adaptada com o objetivo de facilitar a conduta de inoculação, evitar ocorrência de metástase pela 
passagem de agulhas com bisel ou por transfixação para sítios anatômicos adjacentes indesejados, como, por exemplos, tecido muscular, adiposo e vísceras da cavidade abdominal, bem como para restringir o grau de invasividade do processo. No procedimento de inoculação foram utilizados seringa de insulina $\mathrm{BD}^{\circledR}(0,3 \mathrm{cc}$ agulha curta com $8 \mathrm{~mm}$ de comprimento e 0,30 mm de calibre 30-gauge short) procedeu-se à remoção do bisel desta agulha e uso de lixas para ferro Norton ${ }^{\circledR}$ com granulações $600 \mathrm{e}$ 1200; também foram usadas uma lupa Olympus $S Z 40^{\circledR}$ e pinças cirúrgicas.

A inoculação ortotópica foi baseada e modificada do método descrito por F. Behbod (2009). Os animais foram anestesiados conforme descrição anterior, acomodados em decúbito dorsal em ambiente asséptico e sob microscópio estereoscópio. A papila da glândula mamária inguinal foi pinçada e inoculada com 100 $\mu \mathrm{L}\left(1 \times 10^{6}\right)$ de células tumorais frescas ou congeladas no ducto lactífero principal, em ângulo reto. As células, como descrito anteriormente, eram oriundas de repiques semanais ou de alíquotas congeladas por trinta dias. A agulha foi introduzida 1,0 mm diretamente na papila mamária, alcançando os ductos lactíferos (Figura 6 B).
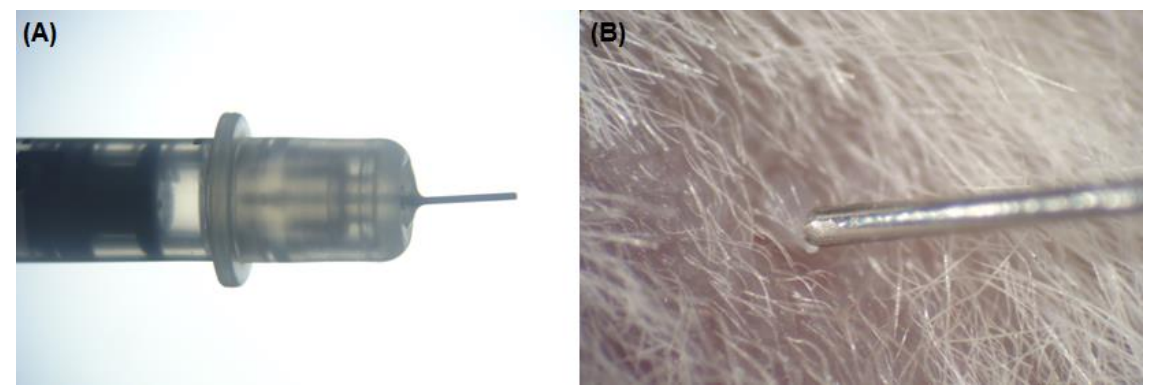

Figura 4: Detalhes da inoculação ortotópica. A) agulha adaptada para a inoculação e (B) comparação dos diâmetros da agulha com $0,3 \mathrm{~mm}$ e da papila com aproximadamente 0, 29 $\mathrm{mm}$.

\section{Curva de Crescimento Tumoral}

Considerando os resultados obtidos anteriormente, em que foram utilizados 100 $\mu \mathrm{L}$ e $1 \times 10^{6}$ (Figura 7) de células tumorais e que os mesmos possibilitaram determinar a evolução do TE nas suas diferentes formas e tempos de inoculação ortotópica, realizouse um experimento com $90 \%$ de redução de volume inoculado de células tumorais frescas, ou seja, $10 \mu \mathrm{L}$ contendo também $1 \times 10^{6}$ de células com um grupo de seis animais. Esse experimento teve por objetivo consolidar um protocolo com o intuito de reduzir a massa tumoral no ducto mamário, minimizar o desconforto nos animais, 
padronizar o volume/peso do tumor e, com isto, a expectativa era coadjuvar com a eficácia da estratégia terapêutica.

\section{Avaliação do volume tumoral para determinação da curva de crescimento}

As dimensões dos tumores foram mensuradas, a cada 24 horas, em todos os grupos experimentais, inclusive no dia da eutanásia, com auxílio de um paquímetro digital milimetrado. O volume foi calculado por meio da fórmula abaixo, na qual D é o maior diâmetro do tumor e $\mathrm{d}^{2}$ refere-se à menor profundidade do tumor (SCHUH, 2004).

$$
\text { Volume }=0.5 \times D \times d^{2} \mathrm{~mm}^{3}
$$

Um paquímetro digital 200MM Pd 200 Vonder® foi usado para realização da mensuração externa dos tumores. O peso dos animais foi determinado por meio de balança digital OHAUS A560 e o peso dos tumores (no dia da eutanásia) em balança analítica modelo OHAUS ${ }^{\circledR} 220$.

\section{Avaliação histopatológica e clínica do tumor obtido por inoculação ortotópica}

A cada 24 horas, os animais eram avaliados para o acompanhamento da evolução clínica do tumor, morbidade ou mortalidade. Foram realizadas inspeções para detecção de alterações morfológicas macroscópicas, tais como presença de nódulos. Quando pertinente, análises microscópicas eram feitas após a eutanásia, em busca de micrometástase, metástase, áreas de necrose, infiltrados e angiogênese. Em cada tumor macroscopicamente visível ou palpável, eram verificados sua progressão, aparência e tamanho. Para a avalição clínica registrava-se o volume do tumor, o peso dos animais e os sinais clínicos como deambulação, agitação ou letargia, respiração, salivação, cianose, consumo de ração/água, de acordo com os parâmetros do Guia para a Condução de Estudos não Clínicos de Toxicologia e Segurança Farmacológica, necessários ao desenvolvimento de medicamentos (ANVISA, 2013).

Secções de vários órgãos e de fragmentos do tumor obtido pela inoculação ortotópica de TE foram submetidos à análise histológica na busca de infiltrados inflamatórios, espessamento, necrose, apoptose, células neoplásticas, entre outras alterações. Para coleta das amostras foi utilizado instrumental cirúrgico para excisar tecido mamário sem tumor, tecido tumoral, baço, fígado, pulmão, linfonodo sentinela 
(linfonodo subiliaco direito), linfonodo contralateral (linfonodo subiliaco esquerdo), mama contralateral e cérebro (plano de cortes apresentado na tabela 2).

Os órgãos e fragmentos foram lavados em solução salina $0,9 \%$ para a retirada de excesso de resíduos e de sangue. Os fragmentos do baço, fígado, pulmão e cérebro foram fixados em formalina $4 \%$ tamponada; o tecido tumoral (tumor sólido), em solução de Davidson. Todas as amostras foram fixadas por oito horas com volume de fixador 20 vezes maior em relação ao tamanho da amostra. O material fixado com a solução Davidson foi mantido a $4^{\circ} \mathrm{C}$ por 8-10 horas, todos os tecidos foram processados para análise histologica em um processador automático de tecidos (Histotécnico OMA ${ }^{\circledR}$, modelo DM-40, São Paulo, Brasil). Em seguida, os fragmentos dos tecidos foram seccionados conforme o plano de inclusão (Tabela 2), entre 2 e $5 \mu \mathrm{m}$ de espessura em um micrótomo manual Leica RM2235 (Leica Microsystems, Nussloch, Alemanha). Cada lâmina foi montada com uma série de 3 cortes semi-seriados $(50 \mu \mathrm{m})$ e corados com hematoxilina-eosina (HE). As fotografias das amostras (lâminas) analisadas foram obtidas em microscópio de luz Carl Zeiss Axio Vision 4.8.2 SP 2 e sistema de captura de imagens de câmera Zen System 2011, programa Blue Edition.

\section{Dosagem de proteína dos fragmentos tumorais}

Para dosagem de proteínas, fragmentos tumorais com cerca de 1,5 mm de comprimento foram incubados com $500 \mu \mathrm{L}$ da solução de extração de proteínas (TrisHCL $25 \mathrm{mM}$, Tween 20 (1\%), água pura QSP) e macerados com auxílio de um homogeneizador mecânico para tecidos e células (Pellet Pestle ${ }^{\circledR}$ Motor). Em seguida, os fragmentos tumorais foram homogeneizados em agitador orbital de tubo vórtex de 280 rpm por dois minutos e incubados por 30 minutos, sob refrigeração. Durante esse período, os fragmentos foram homogeneizados em agitador orbital de tubo, de 10 em 10 minutos. Transcorrido o tempo total (30 minutos), esses homogenatos foram centrifugados $\left(1300 \mathrm{rpm}, 4^{\circ} \mathrm{C}, 5\right.$ minutos $)$ e o sobrenadante foi coletado para posterior dosagem de proteínas. As amostras foram mantidas a $-80^{\circ} \mathrm{C}$ até o momento da análise. Os protocolos e análises da dosagem de proteínas e interleucinas foram realizadas em colaboração com a Dra. Kelly Grace Magalhães do departamento de Biologia Celular do Instituto de Biologia da Universidade de Brasília - UnB. 
Tabela 2: Plano de cortes de inclusão em parafina para histologia

\begin{tabular}{|c|c|c|}
\hline Órgão/tecido & Corte & Inclusão \\
\hline *Tumor/mama & *Longitudinal & $* 1 / 2$, maior volume de contato \\
\hline Mama & Sem plano de corte & Maior volume de contato \\
\hline Baço & $\begin{array}{l}\text { Transversal em } \\
\text { partes iguais }\end{array}$ & $1 / 2$ órgão transversal e $1 / 2$ órgão longitudinal \\
\hline Fígado & Lóbulo $1 / 2$ maior & Maior volume de contato \\
\hline Rins & $\begin{array}{l}1 \text { sem corte/corte } \\
\text { transversal }\end{array}$ & $1 / 2$ órgão vertical e $1 / 2$ órgão horizontal \\
\hline Pulmão & Sem plano de corte & Maior volume de contato \\
\hline Cérebro & $\begin{array}{l}\text { Coronal em partes } \\
\text { iguais }\end{array}$ & $1 / 2$ órgão transversal e $1 / 2$ órgão longitudinal \\
\hline $\begin{array}{l}\text { Linfonodos } \\
\text { subiliacos }\end{array}$ & Sem plano de corte & Maior volume de contato \\
\hline
\end{tabular}

* 1/2 do fragmento tumoral foi processado para dosagem de proteína e de interleucina.

\section{Dosagem de interleucinas nos fragmentos tumorais}

Para avaliar se a inoculação ortotópica do TE induziu alguma alteração imunitária nos animais, os níveis das citocinas IL-12p70 (perfil Th1), IL-4 (perfil Th2), IL-17 (perfil Th17) e citocina pró-inflamatória IL-1 $\beta$ foram analisados.

Fragmentos tumorais de aproximadamente $1,5 \mathrm{~cm}$ de comprimento foram incubados com $200 \mu \mathrm{L}$ de meio de cultura, composto por DMEM (Modified Eagle's Medium Nutrient Mixture) e macerados com auxílio de um homogeneizador mecânico para tecidos e células (Pellet, Pestle ${ }^{\circledR}$, Motor). Após, os homogenatos tumorais foram centrifugados a $4^{\circ} \mathrm{C}(1300 \mathrm{rpm})$ durante cinco minutos. Em seguida, retirou-se o sobrenadante para congelar a $-80^{\circ} \mathrm{C}$. 
Placas de 96 poços foram revestidas com anticorpos de captura durante 24 horas a $4^{\circ} \mathrm{C}$. Após esse período, as placas foram lavadas cinco vezes com tampão fosfato contendo Tween 20 (Sigma) 0,05\% e, em seguida, incubadas por 1 hora com solução de Phosphate Buffered Saline- Fetal Bovine Serum (PBS-SFB) 1\% em temperatura ambiente.

Às placas foram adicionadas as amostras tumorais em análise $(50 \mu \mathrm{L}$ por poço) e, para estabelecer a curva padrão, foram empregadas citocinas recombinantes $(50 \mu \mathrm{L}$ por poço) em concentrações decrescentes de $1 \mathrm{ng} / \mathrm{mL}, 500,250,125,63,31$ e 16 $\mathrm{pg} / \mathrm{mL}$. Após incubar por 24 horas a $4^{\circ} \mathrm{C}$, as placas foram lavadas 5 vezes com tampão fosfato contendo Tween 20 (Sigma) a 0,05\%. Os anticorpos de detecção anticitocina em questão foram adicionados e incubados durante 1 hora em temperatura ambiente. Após essa etapa, as placas foram lavadas três vezes com tampão fosfato contendo Tween 20 (Sigma) $0,05 \%$. O próximo procedimento foi adicionar $50 \mu \mathrm{L}$ de estreptavidina e incubar as placas por 30 minutos em temperatura ambiente. As placas foram lavadas cinco vezes com tampão fosfato contendo Tween 20 (Sigma) 0,05\% e incubadas com 50 $\mu \mathrm{L}$ do substrato TMB (solução de tetrametilbenzidina $36 \mathrm{mM}$ em dimetilsulfóxido (DMSO) 100\%, (100x) diluída em tampão citrato 40 mM e peróxido de hidrogênio 1,27 $\mathrm{mM}, \mathrm{pH} 4,3)$, durante15 minutos. Em seguida, foram adicionados $25 \mu \mathrm{L}$ de solução de ácido sulfúrico $1 \mathrm{M}$ para interromper a reação e as placas foram lidas em leitora de placas a $450 \mathrm{~nm}$. Os dados foram analisados com o programa Soft Max Pro e a dosagem foi baseada na respectiva curva-padrão. Os resultados foram expressos em $\mathrm{pg} / \mathrm{mL}$.

\section{Caracterização do tumor por ecografia}

Na caracterização do TE por imagem foi utilizado o sistema digital de aquisição de imagens de diagnóstico por ecografia, utilizndo-se um ultrassom portátil (Ecografia MINDRAY ${ }^{\circledR}$ DP 6900, Shenzhen Mindray Bio-medical Electronics Co., Ltd. P. R. China). Os animais foram anestesiados por via intraperitoneal conforme descrito previamente, posicionados em decúbito dorsal para tricotomia e aplicação do gel à base de água sobre o sitio de interesse ( $5^{\mathrm{a}}$ glândula mamaria direita). Subsequentemente foi realizada a ecografia nos tempos de 1,2, 7, 14 e 21 dias após inoculação do TE. Os exames ecográficos foram realizados pelo médico veterinário José Luiz Jivago de Paula Rôlo do Instituto de Biologia da Universidade de Brasília - UnB.

\section{Caracterização do tumor por microtomografia computadorizada (MCT)}


Para a caracterização por imagem de MCT, foi utilizado o equipamento SkyScan MicroCT 1076 (SkyScan, Kontich, Bélgica), operando a 50 kV, $141 \mathrm{~mA}$, com o filtro $0,5 \mathrm{~mm}$ de $\mathrm{Al}$. As reconstruções das imagens tridimensionais (3D) foram realizadas com software Nrecon (SkyScan, Kontich, Bélgica), empregando os padrões "smoothing", "beam-hardening" e "ring-artifact", com os valores 01, 10 e 07, respectivamente. $\mathrm{Na}$ avaliação das imagens 3D, foi utilizado o software CTanalyze (SkyScan, Kontich, Bélgica). Para os procedimentos de caracterização tumoral nos tempos de 1, 2, 7, 14 e 21 dias após inoculação de TE, por MCT, todos os animais foram anestesiados conforme descrição anterior, posicionados no porta-animal do equipamento e fixados em decúbito dorsal, a fim de prevenir qualquer tipo de movimentação durante o escaneamento. Os sinais vitais foram monitorados antes, durante e após os procedimentos, especialmente no sítio de interesse, a $5^{\mathrm{a}}$ glândula mamária direita.

\section{Análise estatística}

As análises estatísticas deste estudo foram realizadas usando o software SPSS (Statistical Package for the Social Sciences) versão 18.0. As variáveis contínuas foram testadas para avaliar normalidade com o teste de Shapiro-Wilk. Possíveis diferenças entre os grupos analisados foram investigadas pelos testes T de Student ou MannWhitney (quando os dados não estavam normalmente distribuídos). As comparações foram apresentadas por meio de diagramas de caixas ou gráficos de colunas. Valores de $\mathrm{p}<0,05$ foram considerados estatisticamente significativos. 


\section{RESULTADOS}

\section{Microanatomia da mama do camundongo Swiss}

No camundongo Swiss fêmea foram identificados cinco pares de glândulas mamárias arranjadas em duas linhas paralelas e harmônicas, posicionadas ventrolateralmente, exteriorizando as papilas mamárias circundadas por aureola, com ausência de pelagem. Distribuídas no eixo craniocaudal, elas ocupam as posições cervical, torácica (cranial e caudal), abdominal e inguinal (Figura 7A e B).

A microdissecção, coloração e análises histológicas realizadas revelaram que a árvore ductal das glândulas mamárias é composta por um ducto principal (DP), medindo aproximadamente $3,5 \mathrm{~mm}$ de comprimento e 0,51 $\mathrm{mm}$ de diâmetro (figura 7C), que se ramifica em ductos acessórios, ductos lobares, ductos lobulares (DL), ductos terminais e múltiplos ácinos glandulares (Figuras 7 e 8).

As glândulas cervicais se expandem cranialmente em direção às glândulas submandibulares e parótidas, até ocupar a porção posterior da mandíbula, com sobreposição medial e contralateral ao nível da região gular; circundam os membros anteriores com expansão supraescapular até a região medial e com sobreposição contralateral na região cervical (Figura 7A).

As glândulas torácicas se apresentam justapostas, com projeção laterodorsal que se estreita progressivamente em direção dorso-medial (Figura 7A). As glândulas abdominais se expandem craniocaudal e dorsolateralmente, sobrepondo-se ao par de glândulas inguinais, as quais, por sua vez, se expandem dorsal, lateral e caudalmente, envolvendo as regiões genital, perineal e perianal, com leve expansão lateral subcaudal, sobrepondo-se contralateral e ipsilateralmente com as glândulas abdominais (Figura 7B).

O estudo da distribuição das glândulas mamárias cervicais do camundongo em lactação, por microdissecção, revelou a mesma rede ductal que nos camundongos virgens (Figuras 7 (A) e 9 (A e B). Notadamente, observou-se, tomando como referência externa, as papilas das glândulas mamarias cervicais, grande expansões, inferiormente para a região submandibular, sobrepondo-se até a região gular, contornando os membros inferiores, passando pela região subescapular até sobrepor-se na região cervical. 

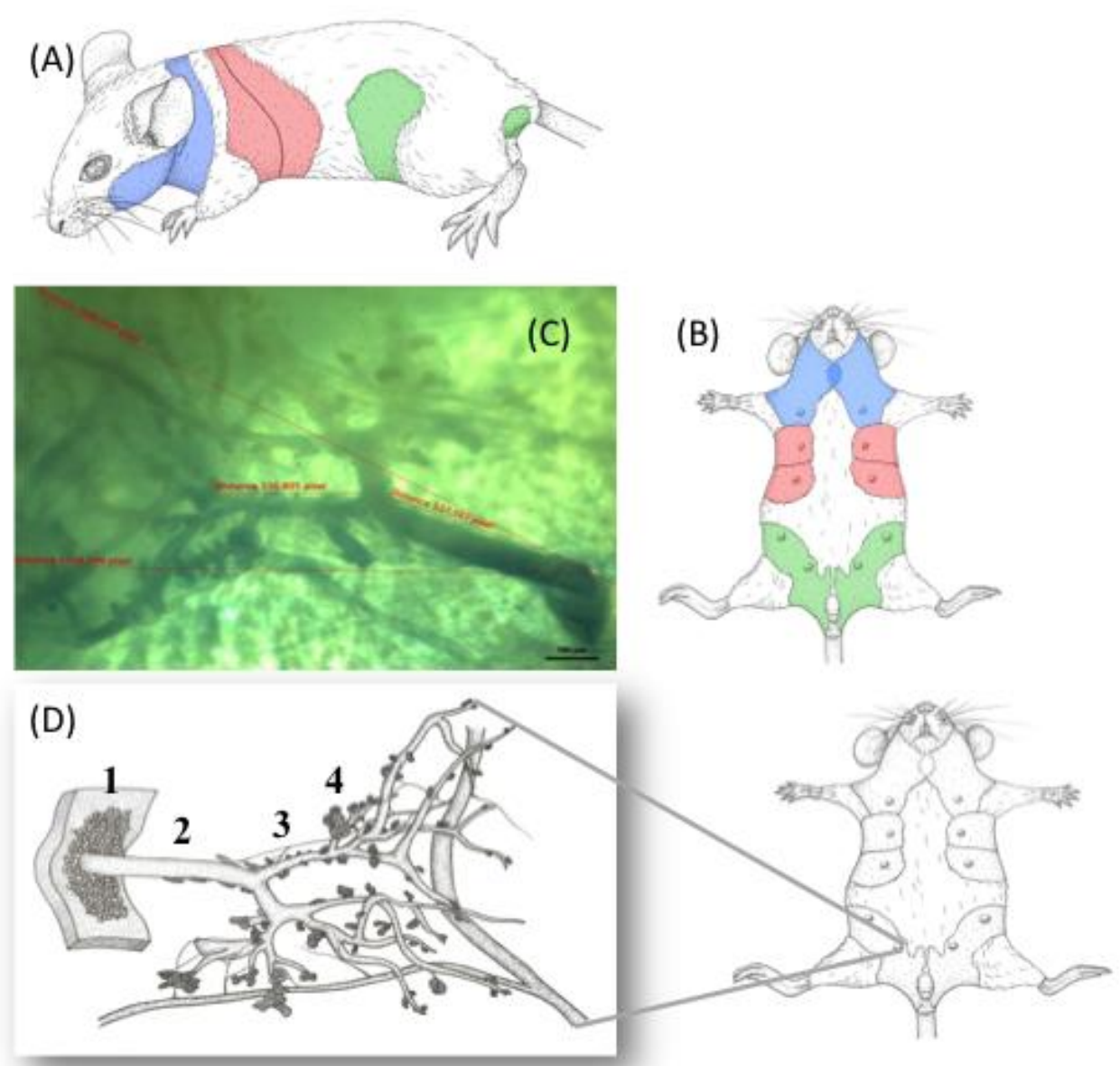

Figura 5: Representação da distribuição das glândulas mamárias em camundongo Swiss. A e B, camundongo em visão lateral esquerda e em decúbito dorsal, respectivamente. Em Azul, pares de glândulas mamárias cervicais com sobreposição da área ductal lactífera. Em rosa, dois pares de glândulas mamárias torácicas; em verde, um par de glândulas mamárias abdominais e um par de glândulas mamárias inguinais; C, medidas de ductos mamários de um camundongo Swiss mostrando duto principal medindo cerca de $3,5 \mathrm{~mm}$ de comprimento e $0,51 \mathrm{~mm}$ de diâmetro; D, ilustração da distribuição ductal e detalhes da glândula mamária de camundongo Swiss: 1, coxim adiposo, 2, ducto principal; 3, capilar; 4, ácino/alvéolo.

\section{Mapeamento linfático e Linfonodo Sentinela (LNS) de animais saudáveis e portadores de tumor}

O mapeamento linfático e o LNS de um animal controle sadio, após administração de corante vital, estão mostrados na Figura 10. Macroscopicamente, o LNS ipsilateral pode ser visto na $5^{\mathrm{a}}$ glândula mamária, vasos linfáticos e vasos sanguíneos aferentes e eferentes do hilo do linfonodo. 


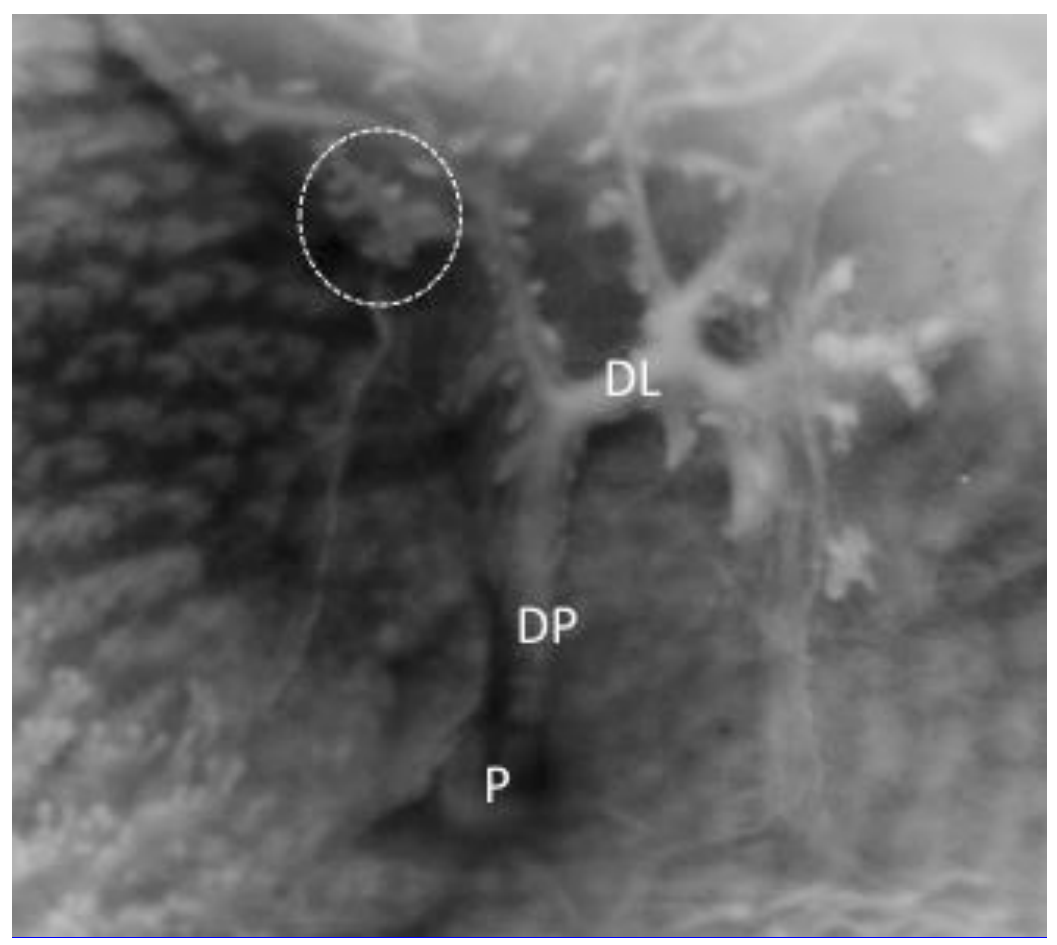

Figura 6: Glândula mamária de camundongo Swiss fêmea: fotografia da $5^{\text {a }}$ glândula mamária (inguinal) de animal com 55 dias de idade, coloração Azul de Tripan injetado diretamente no ducto principal, $\mathrm{P}=$ papila mamária, $\mathrm{DP}=$ ducto lactífero ou principal, $\mathrm{DL}=$ ductos lobulares e circulo pontilhado mostra um conjunto de ácinos. Fotografia obtida em microscópio de luz Carl Zeiss. Axio Vision 4.8.2 SP 2, e o sistema de captura de imagens através de câmera Zen System 2011, programa Blue Edition.
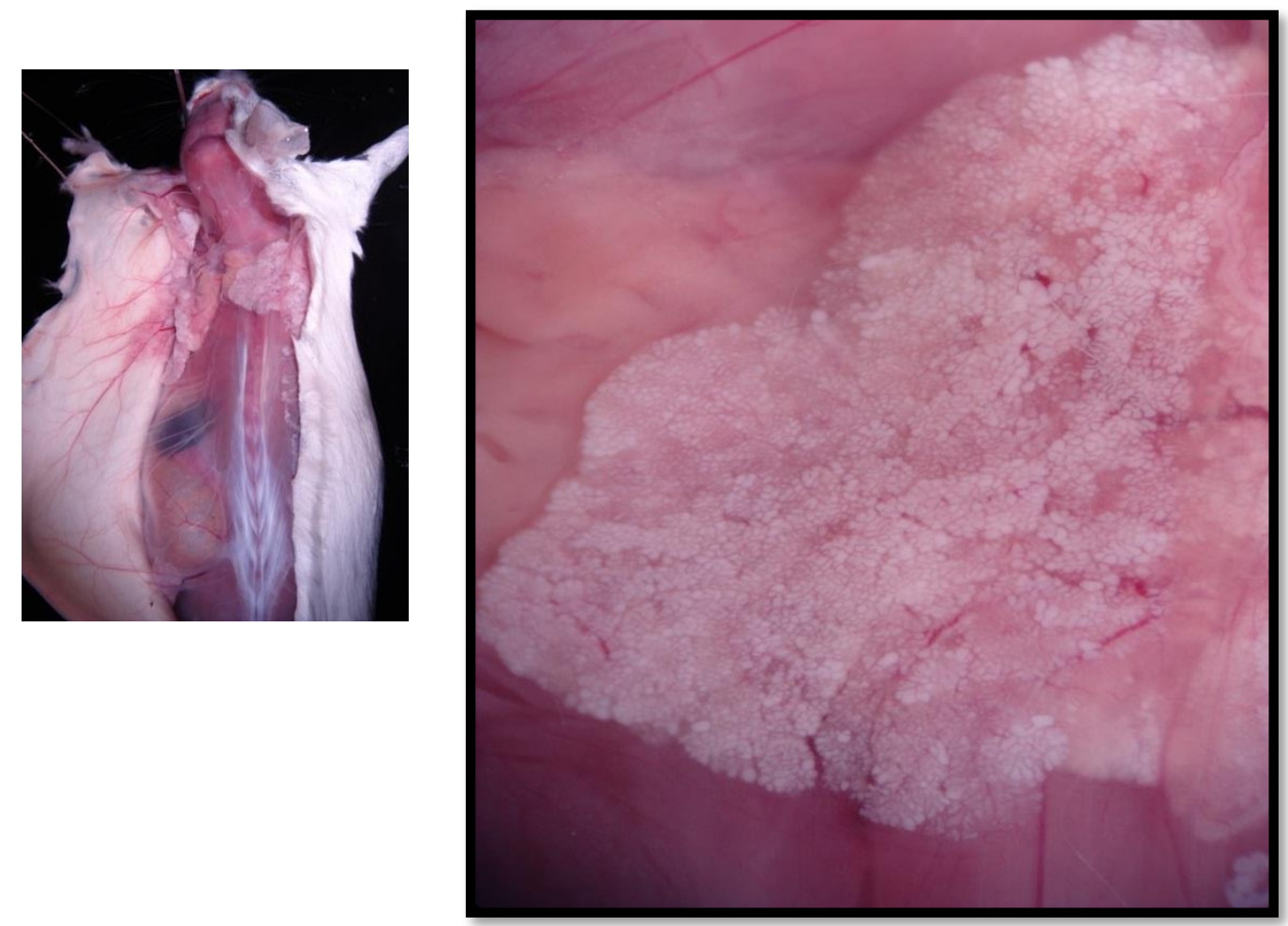

Figura 7:Detalhe macroscópica da glândula mamária de camundongo lactante. A, Microdissecção da glândula mamária de camundongo Swiss (lactante 21 dias), incisão sagital dorsal, apresentando uma das glândulas mamárias cervicais com expansão para a região cervical póstero dorsal e lateral, B - detalhes macroscópicos da glândula. 

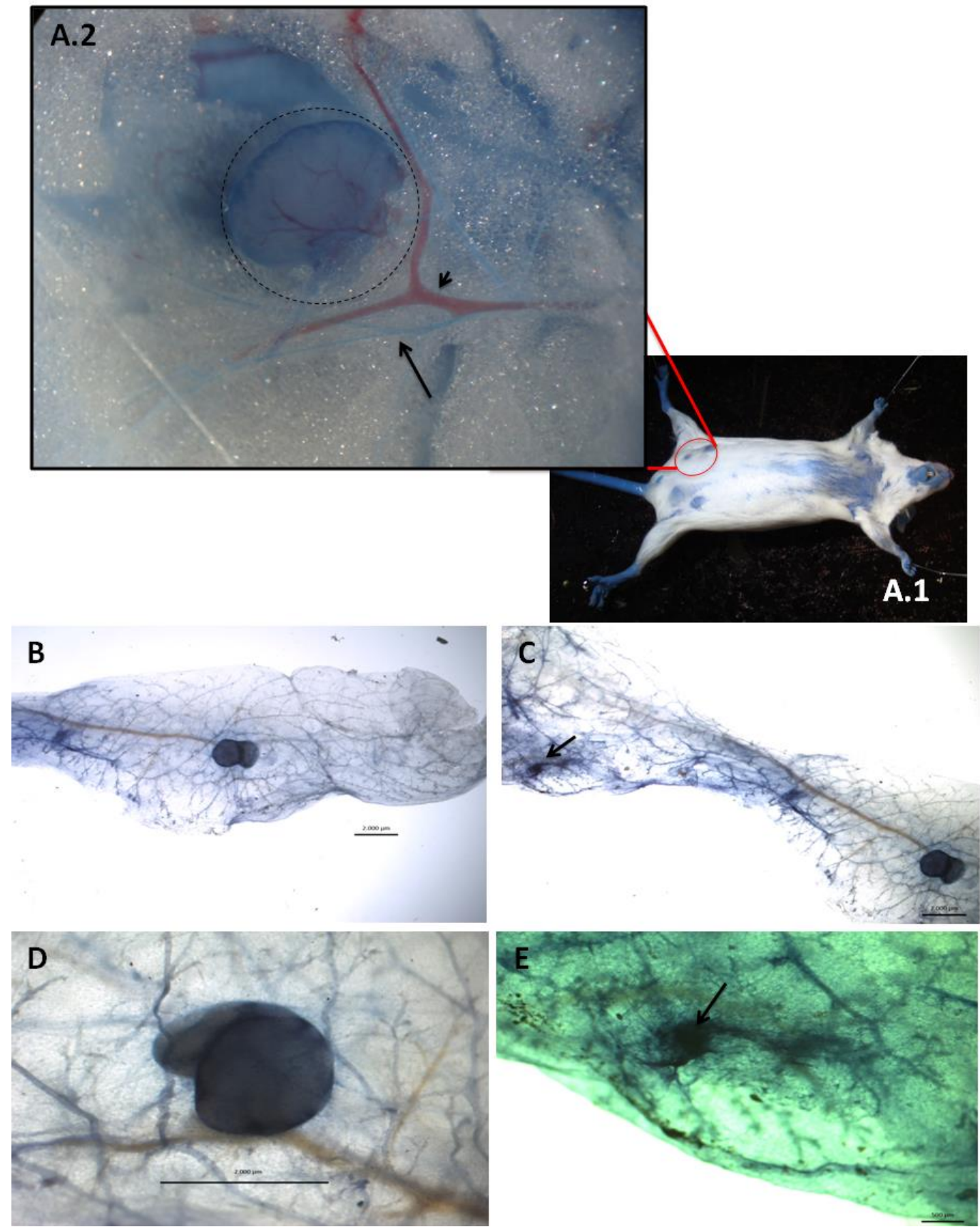

Figura 8: Mapeamento linfático e linfonodo sentinela (LNS) da $4^{\text {a }}$ e $5^{\text {a }}$ (direita) glândulas mamárias normais (A1), camundongo submetido à coloração vital com o Azul de Tripan; (A2), círculo pontilhado indica o linfonodo sentinela (linfonodo subiliaco direito), a seta curta, um vaso sanguíneo e a seta longa, vaso linfático; (B), linfonodo sentinela da $5^{\text {a }}$ glândula mamária (linfonodo subiliaco direito); (C), seta indica LNS na $4^{\mathrm{a}}$ glândula mamária e em (D)- detalhe do linfonodo sentinela da $5^{\text {a }}$ glândula mamária (linfonodo subiliaco direito) (E)- detalhe da figura mostrada em (C). 
Observou-se invasão tumoral nos LNS ipsilateral (linfonodo subiliaco direito) em $85 \%$ dos animais do grupo controle, após 7 dias, o que indica a presença de micrometástase. Entretanto, 14 dias após a inoculação das células TE, havia depósitos metastáticos no LNS ipsilateral $100 \%$ e no linfonodo contralateral $50 \%$, em dois animais respectivamente (dados não mostrados).

\section{Avalição clínica, evolução e mensuração tumoral}

Após inoculação das células TE, os animais foram avaliados clinicamente todos os dias, até o final do experimento (nos tempos 1, 2, 7, 14 e 21 dias). Baseado nos parâmetros do Guia para a Condução de Estudos não Clínicos de Toxicologia e Segurança Farmacológica, necessários ao desenvolvimento de medicamentos (ANVISA, 2013), os animais não apresentaram sinais ou sintomas clínicos, comportamentais e patológicos anormais durante todos os experimentos.

Ao serem detectados, os tumores eram medidos após a eutanásia. A figura 11 ilustra nas primeiras observações do tumor, evidenciando as diferenças encontradas 1 dia após a inoculação ortotópica de células TE frescas entre a quarta (não inoculada) e a quinta glândula mamária. Na figura 11B é ilustrada medida do tumor no animal vivo e nas figuras $11 \mathrm{C}, \mathrm{D}$, o procedimento de microdissecção do tumor ao final do experimento e sua medida, respectivamente.

A evolução do tumor foi avaliada repetindo-se este procedimento (medição por paquímetro) até o $21^{\circ}$ dia do experimento, tanto após a inoculação de células TE congeladas (Figura 12), quanto de células frescas (Figura 13).

Após a eutanásia dos animais, os tumores dos animais, além de medidos (Figuras 12 e 13), tinham seu aspecto avaliado in situ (Figura 14A), eram submetidos à microdissecção (Figura 14B e sua localização intraductal comprovada (Figura 14C). A microdissecção e coloração possibilitou também verificar o processo de angiogênese (Figura 14D).

\section{Curva de Crescimento Tumoral}

A inoculação de células TE congeladas $(100 \mu \mathrm{L})$ não induziu crescimento do tumor até o $14^{\circ}$ dia (Figura 15). Entretanto, a curva de crescimento do tumor obtida pela inoculação de células TE frescas revela que o desenvolvimento do tumor iniciou já um dia (24 horas) após esse procedimento, como pode ser observado também por avaliação 
clínica e histológica. É demostrada na curva de crescimento referente às células frescas, em desenvolvimento do tumor logarítmico entre 7 e 14 dias, tanto nos resultados in vitro, como in vivo por avaliação por microtomografia computadorizada (MTC). Durante este periodo (7 e 14 dias), foram detectadas metástases no LNS e no LN. Por esta razão, o perfil de citocinas foi realizado no período experimental de 14 dias após a inoculação de TE.
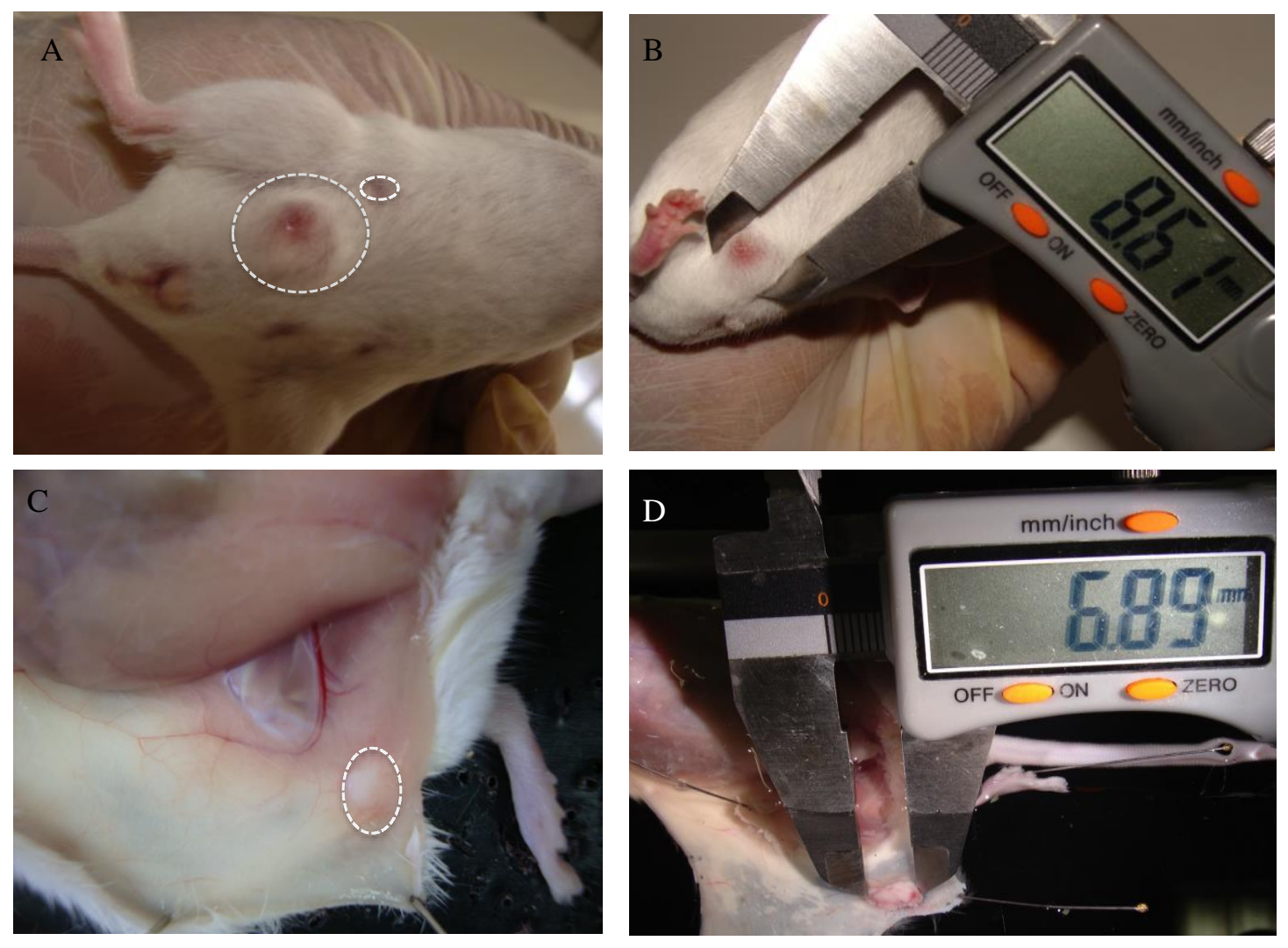

Figura 9: Caracterização do tumor de Ehrlich in situ 24 horas após inoculação de células tumorais TE frescas. A - O circulo pontilhado menor mostra aspecto da quarta glândula mamária sem alterações morfológicas e o círculo pontilhado maior indica a quinta glândula mamária (inoculada), com edema localizado e hiperemia ativa. B - mensuração do tumor in situ, C - microdissecção parcial da glândula e do tumor, D- Tumor microdissecado e mensurado. 


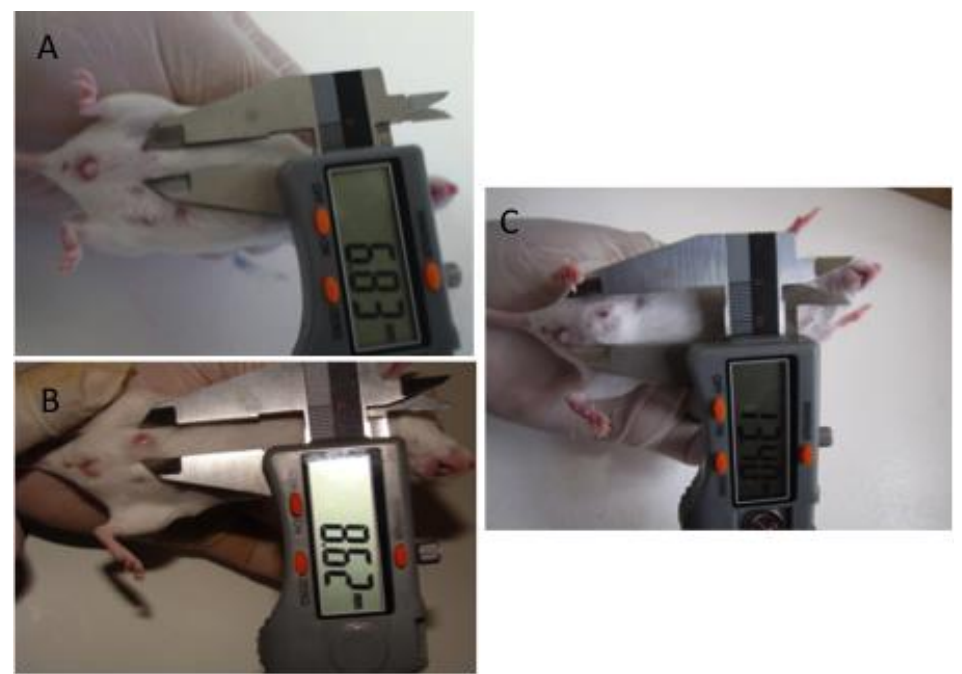

Figura 10: Evolução tumoral 7, 14 e 21 dias após inoculação de células TE congeladas por 30 dias. Aspecto do tumor in situ com avaliação clínica: A e B células tumorais congeladas por 30 dias e com 14 dias de inoculação, C e D células tumorais congeladas por 30 dias e com 21 de inoculação e avaliação clínica, A B C e D = inoculação tumoral ortotópica, B e D= mensuração do tumor

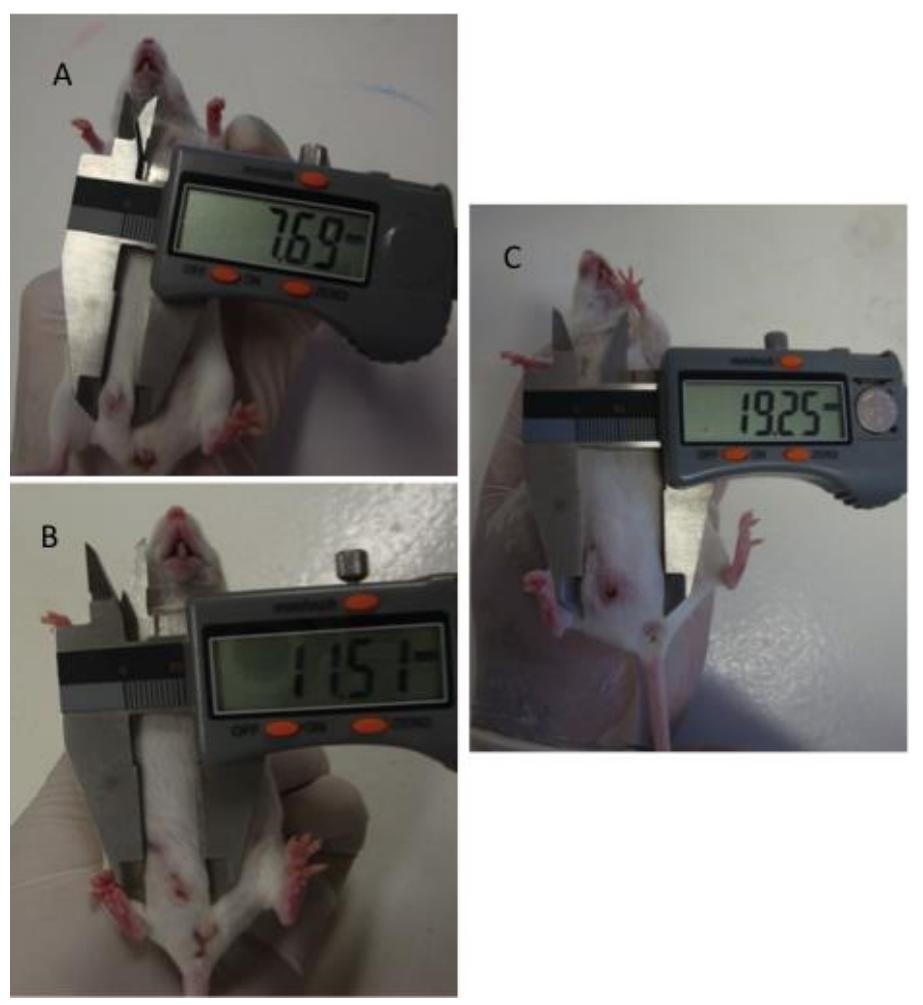

Figura 11: Evolução tumoral 7, 14 e 21 dias após inoculação de células TE frescas.Aspectos do tumor in situ, inoculaçãoo ortotópica com células frescas (repique), A- Inoculação com 7 dias, B- Inoculação com 14 dias e C- inoculação com 21 dias 

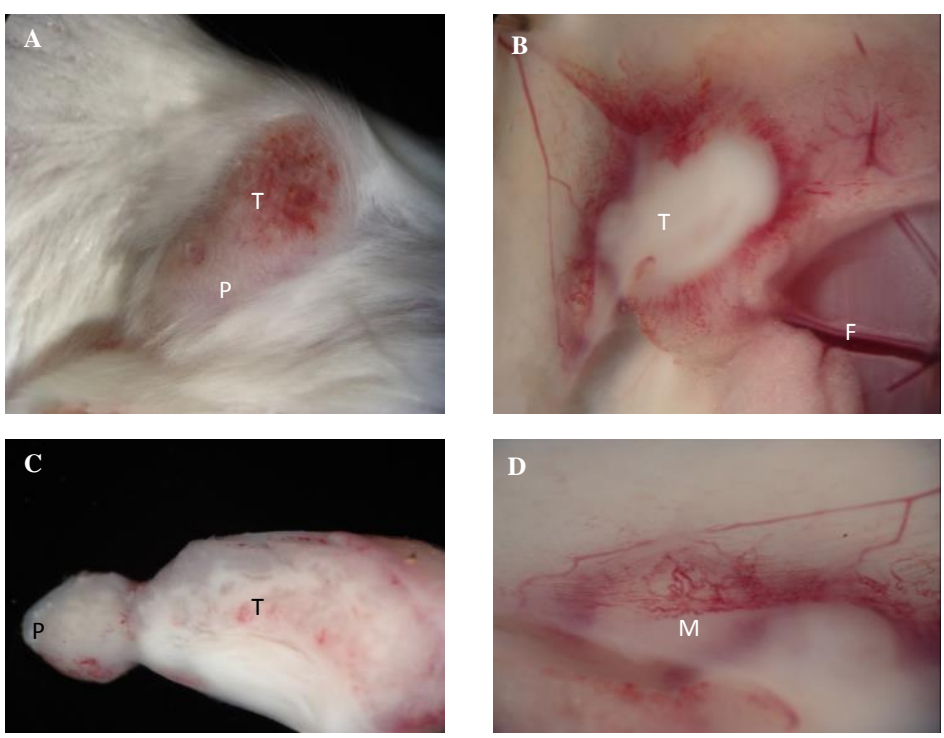

Figura 12: Fotografia dos aspectos macroscópicos tumorais no sítio de inoculação do TE, (in situ) e após microdissecção células frescas com 7 dias de inoculação: (A) Tumor in situ (aspecto externo), $\mathrm{P}=$ papila mamária, $\mathrm{T}=$ hiperemia tumoral. (B) $\mathrm{T}=$ tumor in situ (microdissecção) e $\mathrm{F}=$ Feixe vasculho nervoso. (C) Tumor no ducto mamário principal, $\mathrm{P}=$ papila mamária $\mathrm{T}=$ tumor dentro do ducto principal. (D) Microcirculação do tumor (angiogênese).

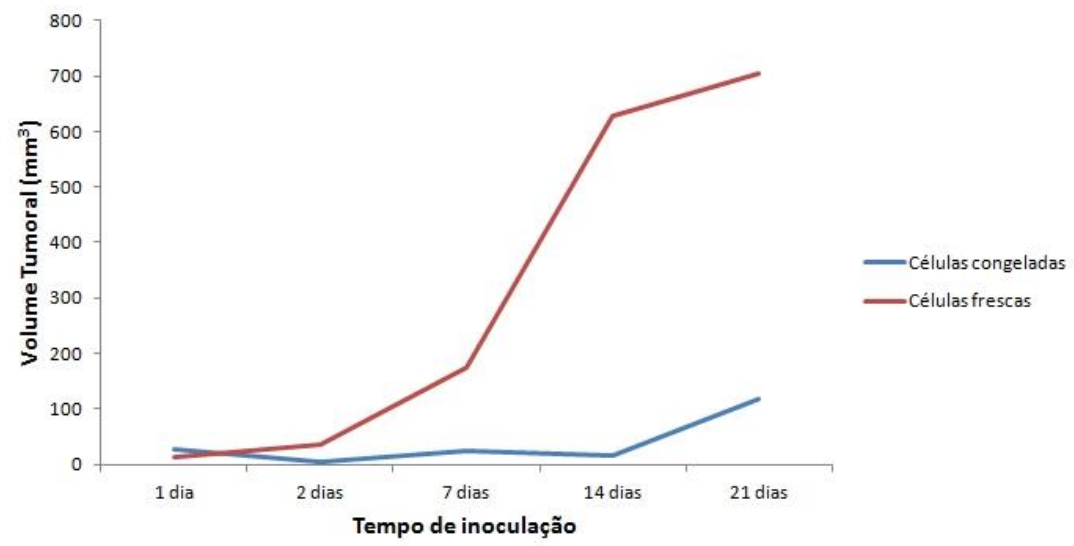

Figura 13: Curva de crescimento tumoral após inoculação ortotópica de $100 \mu \mathrm{L}$ de $1 \times 10^{6}$ células frescas (linha vermelha) e congeladas (linha Azul) TE em camundongo Swiss.

De acordo com os dados referentes ao volume do tumor mostrados na figura 15 , não há diferença estatisticamente significativa entre crescimento obtido a partir de células congeladas e de células frescas nos primeiros tempos experimentais $(1,2$ e 7 dias). Nos tempos de 14 e 21 dias após inoculação de TE, o crescimento tumoral apresentou diferença estatisticamente significativa entre os grupos. 
A influência do volume do inóculo de TE no crescimento tumoral também foi investigada. Por meio de testes não-paramétricos (Teste de Mann-Whitney) mostraram que o volume tumoral após inoculação de $100 \mu \mathrm{L}$ de células tumorais é significativamente maior do que quando são inoculados apenas $10 \mu \mathrm{L}$ de TE, ambos experimentos foram utilizadas $1 \times 10^{6}$ de células (Figura 16).

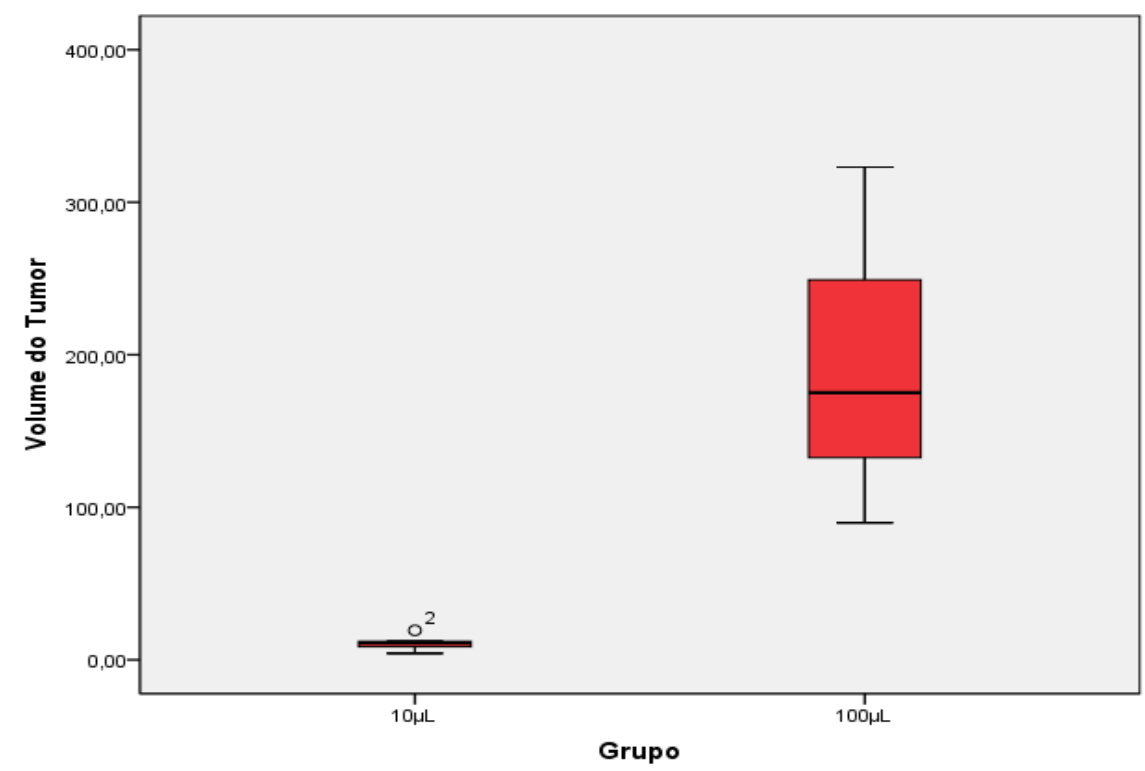

Figura 14: Crescimento tumoral 7 dias após inoculação ortotópica de $10 \mu \mathrm{L}$ ou 100 $\mu \mathrm{L}$ de células frescas TE, em ambos experimentos foram utilizadas $1 \times 10^{6}$ de células .

\section{Análise histológica de órgãos e tumores}

Em todos os grupos controle (negativo, positivo e tumor) avaliados, nos tempos de 1, 2, 7, 14 e 21 dias após, os pulmões, cérebros, fígados, baços e rins mostraram-se sem alterações morfológicas, tais como anormalidades nas células, infiltrados inflamatórios, apoptose, hemorragia, necrose ou comprometimento estrutural do órgão. Entretanto, em um animal do grupo controle negativo no tempo de 14 dias foi evidenciado no pulmão infiltrado inflamatório mononuclear com predominância de macrófagos.

Ainda nos grupos controles, os cortes histológicos de glândulas mamárias não lactantes apresentaram parênquima mamário com estrutura ductal e lobular sem alterações hiperplásicas. Raras células mononucleares estavam presentes no estroma lobular (dados não mostrados). 
O exame histopatológico das mamas com inoculação tumoral revelou a presença de tumores indiferenciados (Figura 17) com grandes áreas necróticas invadindo a glândula mamária hospedeira, incluindo a destruição das estruturas ductais. Este agravo foi proporcional ao tempo decorrido após a inoculação do tumor. Características tumorais estão ilustrados após 7 dias (Figura 17 A-F), 14 dias (Figura 17 G-J) e 21 dias (Figura $17 \mathrm{~K}-\mathrm{L}$ ). A partir de 7 dias, a derme adjacente e a musculatura esquelética já apareciam infiltrados com células tumorais. Verificou-se invasão dos vasos linfáticos observada frequentemente tanto no tumor, quanto no tecido mamário peritumoral adjacente, endomísio muscular e derme. A partir de 14 dias, micrometástases e metástases foram identificadas no linfonodo sentinela (linfonodo subliaco direito) e no linfonodo contralateral (linfonodo subliaco esquerdo), além de anisocariose acentuada. Nos tumores de animais com TE inoculados há 21 dias da inoculação de TE (Figura 17 $\mathrm{K}-\mathrm{L}$ ), além das metástases, notou-se as grandes áreas de necrose eosinofílicas características do tumor de Ehrlich. Invasão tumoral nos feixes neurovasculares e metástases focais no tecido adiposo mamário foram raramente observadas (dados não mostrados).

\section{Análise de imunomodulação por TE}

Células TE frescas e congeladas ortotopicamente inoculadas na glândula mamária induziram respostas diferentes em relação ao perfil de citocinas (Figura 18). A inoculação de células TE frescas induziu aumento significativo da secreção de IL-4 (Figura 18A) e IL-1 $\beta$ (Figure 18C), quando comparado às glândulas mamárias normais (controle). A secreção de IL-1 $\beta$ também foi maior do que a observada para as células congeladas.

Além disto, a secreção de IL-17 não alterou significativamente após a inoculação das células frescas (Figura 18B). Entretanto, após inoculação das células TE congeladas, a secreção de IL-17 (Figura 18B) foi significativamente maior, tanto em relação ao controle, como a observada após inoculação de células frescas. Níveis de IL12 p70 não foram detectados para células frescas e também para as congeladas (dados não mostrados). 

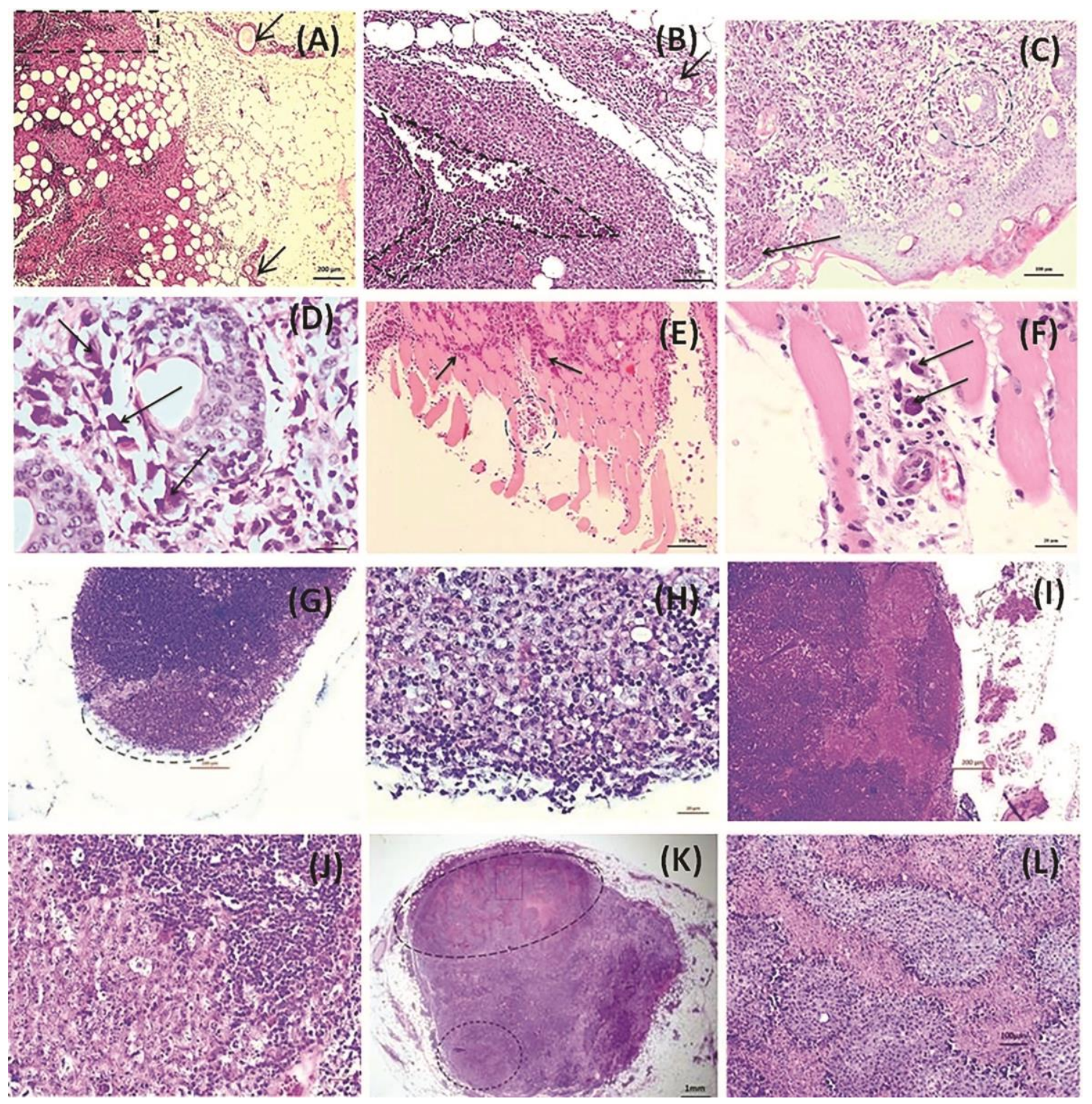

Figura 15: Caracterização histológica do tumor após 7 dias (A-F), 14 dias (G-J) e 21 dias (K-L), mostrando: (A) tumor invasivo na glândula mamária adjacente a uma área normal e estruturas ductais normais (setas); (B) detalhe, área retangular selecionada na Fig. A fronteira mostrando invasão e estruturas ductais normais (setas); (C) pele do camundongo mostrando invasão tumoral dérmica, com erosão da epiderme, no canto inferior esquerdo da imagem (seta); (D) detalhes da área selecionada na Fig. C, mostrando células tumorais aberrantes no interior do vaso linfático perifolicular (setas); (E) invasão endomisial extensiva dos músculos esqueléticos (setas) situados abaixo e adjacentes à glândula mamária; (F) Detalhes da área selecionada na Fig. E, demostrando um vaso linfático com células tumorais (setas); (G) Metástase em linfonodo sentinela (SLN) subcapsular (área selecionada); (H) Detalhe da Fig. G revelando um grupo sólido de células tumorais que apresentam nucléolo claro e anisocariose acentuada; (I) O linfonodo sentinela (SLN) com uma metástase que se estende desde a subcapsular para o córtex do linfonodo (área selecionada); (J) Detalhe da Fig. I, mostrando as células tumorais adjacente ao linfonodo de parênquima normal; Linfonodo (K) sentinela (SLN), mostrando uma lesão metastática (grande elipse) e uma pequena micromestástase sólida (elipse pequena); (L) Detalhe da Fig. K (selecionada área retangular dentro da grande elipse) evidenciando o padrão característico do tumor de Ehrlich primário com extensas áreas de necrose eosinofílicas. 

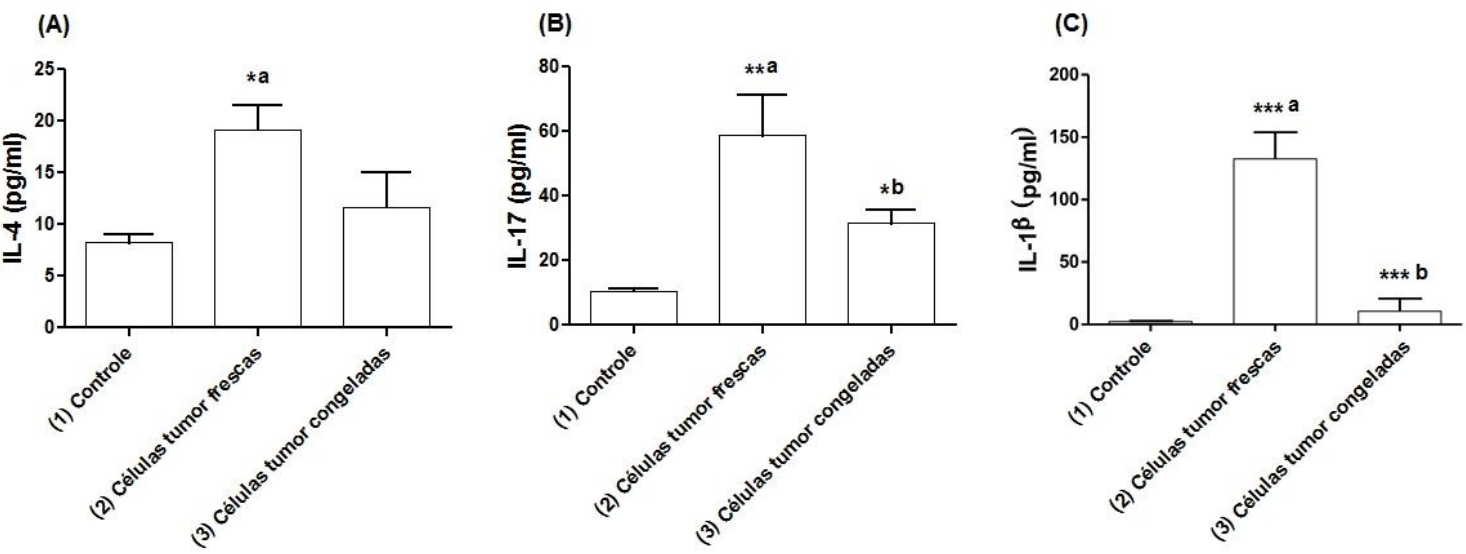

Figura 18: Dosagem de Interleucinas (IL) em lisados de glândula mamária avaliada 14 dias após inoculação de células frescas ou congeladas de tumor de Ehrlich, usando glândulas mamárias normais como controle. (A) IL-4; (B) IL-17; (C) IL-1 $\beta$. Os dados foram expressos como média e EPM (erro padrão da média). Para IL-4 e IL-17, os valores de p foram gerados por ANOVA, enquanto para a IL-1 $\beta$, pelo teste de Kruskall-Wallis. As letras minúsculas indicam diferenças significativas detectadas pelos testes de Tukey (IL-4 e IL-17) ou de Dunn (IL-1 $\beta$ ), com a= significativo em relação ao controle; $b=$ significativo em comparação com células tumorais frescas. Os asteriscos indicam diferenças significativas ao nível de $* \mathrm{p}<0,05, * * \mathrm{p}<0,01$ e $* * * \mathrm{p}<0,001$.

\section{Caracterização do tumor por imagens em camundongos portadores de tumor por imagem}

Ecografia

A presença de tumor foi comprovada por ecografia da região mamária (inguinal direita). Para ilustrar, a figura 19 é mostrada área (destacada por linha tracejada oval) com ecogenicidade mista, evidenciando região com $200 \mathrm{~mm}^{2}$, condizente com aspecto tumoral.

\section{Microtomografia computadorizada}

As microtomografias computadorizadas (MCT) da parede abdominal dos animais dos grupos inoculados com células TE frescas (Figura 20) mostraram massa tumoral (nódulo isolado) com forma e margem irregulares na glândula mamária inguinal direita, apresentando imagem com isoecogenicidade (mesma textura) e densidade que corresponde às partes moles do tecido mamário (comparar controle Fig. 20A com tumores Fig. 20B-E). As imagens de MTC confirmam a implantação do tumor um dia (24 horas) após a inoculação do tumor e revelam a expansão da lesão com deformação progressiva do tecido (lesão empurrando as estruturas adjacentes) (Figuras 20B-E), particularmente 14 dias após a inoculação (Figura 20D). A técnica permitiu também obter imagens tridimensionais do tumor, como ilustrado na figura 20F. 


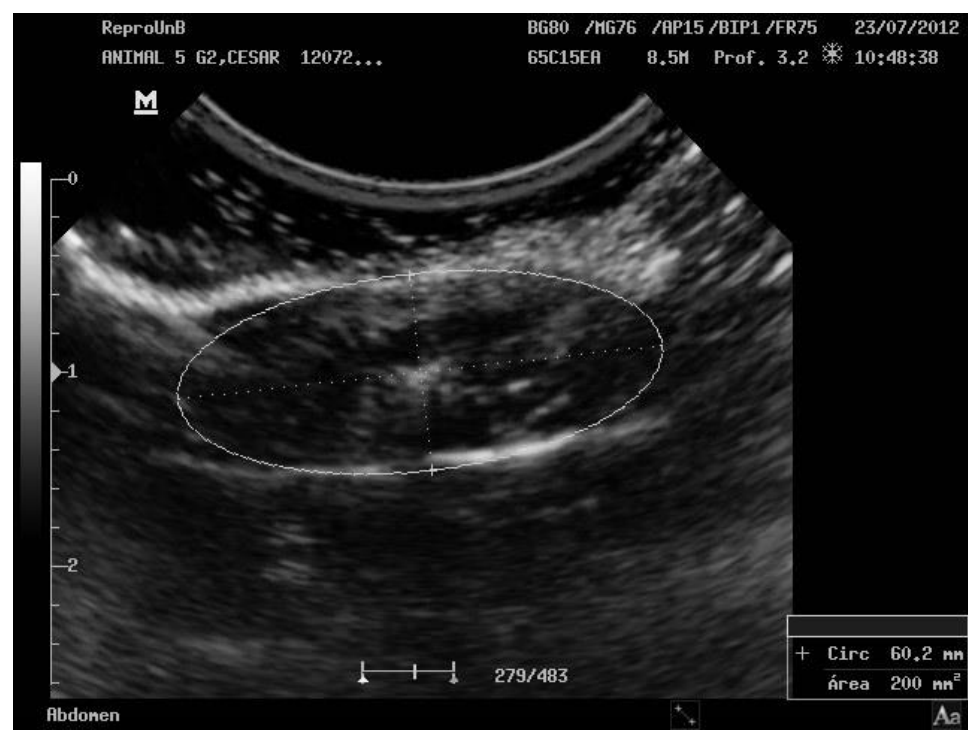

Figura 16: Ecografia da região mamária de camundongo (inguinal direita), realizada 24 horas após implante de células TE frescas; área em destaque evidencia presença de tumor.
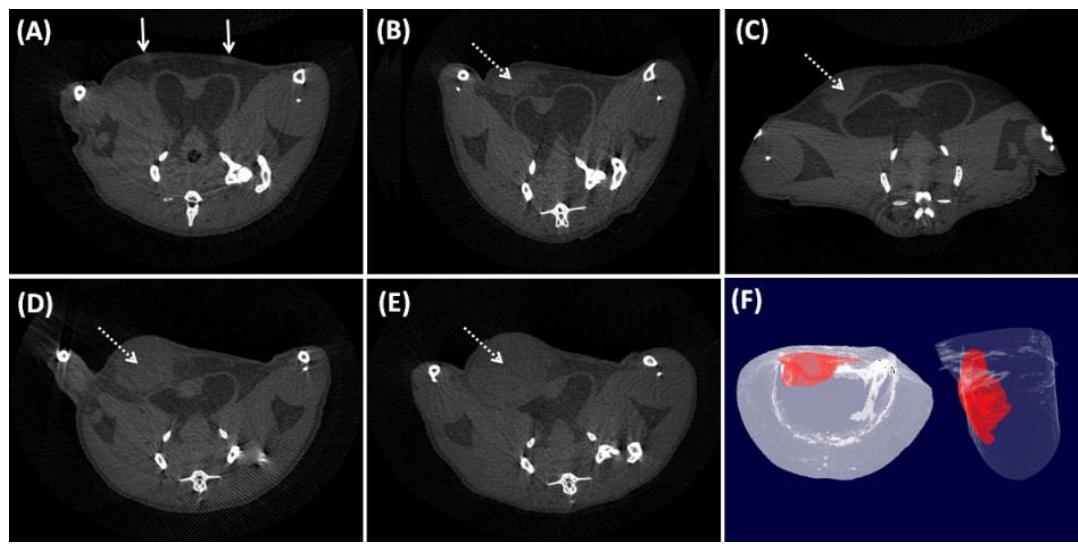

Figura 17: Microtomografias computadorizadas (MCT) da parede abdominal no plano axial e vista inferior: (A) grupo controle, mostrando glândulas mamárias normais (setas sólidas); (B) imagem nodular um dia (24 horas) após inoculação de células tumorais TE, mostrando lesão de $2,572 \mathrm{~mm} \times 5,355 \mathrm{~mm}$ na glândula mamária inguinal direita (seta tracejada), com densidade de partes moles, forma e margens irregulares; (C) imagem nodular 7 dias após inoculação de células TE (seta tracejada), medindo $3,455 \mathrm{~mm} \times 5,435 \mathrm{~mm}$; (D) imagem nodular 14 dias após inoculação de TE (seta tracejada), mostrando lesão expansiva de 6,352 $\mathrm{mm} \times 7,355 \mathrm{~mm}$ na glândula mamária inguinal direita, com efeito de massa progressiva (lesão empurrando as estruturas adjacentes; (E) imagem nodular 21 dias após (seta tracejada) medindo 7,592 $\mathrm{mm} \times 8,81 \mathrm{~mm}$; (F) imagens em 3D do tumor (vermelho), ao fim de 14 dias. 


\section{DISCUSSÃO}

Novas terapêuticas para o câncer demandam estudos pré-clínicos. Os modelos tumorais para os estudos pré-clínicos são classificados em duas categorias principais: os que empregam a inoculação de células tumorais e aqueles em que os tumores aparecem espontaneamente ou são induzidos quimicamente (WORKMAN et al., 2010). Embora não reproduza as múltiplas etapas características da evolução tumoral, o primeiro grupo é empregado com mais frequência devido à menor demanda de tempo para o aparecimento do tumor e assim agilidade nos estudos.

Muitas espécies animais podem ser usadas nestes estudos pré-clínicos, mas o camundongo é o mais comumente empregado como modelo de câncer de mama (ANDRADE et al., 2002; WORKMAN et al., 2010). Apesar das diferenças morfológicas entre o tecido mamário humano e o dos camundongos, o entendimento do câncer de mama tem apontado muitas similaridades funcionais em ambos tecidos (VISVADER, 2009). Estas similaridades, aliadas à fácil acessibilidade, fazem com que a glândula mamária do camundongo seja o órgão mais amplamente empregado quando se tem o propósito de compreender as propriedades celulares e moleculares fundamentais do desenvolvimento normal e neoplásico (RUSSO et al.,1996; VISVADER, 2009; MEDINA, 2010) .

Embora importante, os mapeamentos das redes ductais, do sistema linfático e linfonodo sentinela (LNS) das glândulas mamárias do camundongo Swiss, frequentemente usado como modelo, não estavam descritos na literatura. No presente trabalho, a microanatomia detalhada da glândula mamária e o mapeamento linfático, inclusive do LNS, foram descritos, sendo a nomenclatura, localização e distribuição correspondentes aos de VAN DEN BROECK e cols. (2006), resultados de estudos realizados em camundongos BALB/c. A descrição histopatológica adicional e a caracterização do modelo de inoculação ortotópica do tumor por microtomografia computadorizada (MTC) fazem com que o modelo apresentado seja útil para investigar mais profundamente os mecanismos fundamentais da malignidade, os novos métodos de prevenção, diagnóstico e tratamento do câncer de mama.

Ainda que a grande maioria dos dados da literatura seja referente à inoculação ectópica (SUGIURA, 1953; AABO et al., 1994; de SOUZA et al., 2006; SAROJA et al., 2012; MIRANDA-VILELA et al., 2013; CHEKULAYEVA et al., 2014;), há relatos sobre a inoculação ortotópica de células tumorais (KUBOTA, 1994; WITZ, 2009; 
PEIXOTO, et al., 2015). Contudo, não foram encontrados os relacionados ao tumor de Ehrlich. É conhecido que implantes ortotópicos podem reproduzir mais apropriadamente o ambiente do órgão no qual o tumor cresce, de tal forma que o efeito do tumor em seu microambiente pode ser modulado (RICHMOND, 2008). Dessa forma, o tumor ortotópico parece ser um melhor preditor de sucesso clínico que o modelo ectópico (KILLION et al., 1998; HOFFMAN, 1999). Está bem estabelecido que a invasividade gerada pela inoculação ortotópica aumenta a probabilidade de metástases (RASHID, 2013; KOCATÜRK et al., 2015) causadas por injúrias mecânicas que podem até mesmo levar a uma expressão aumentada de oncogenes, promovendo a metástase do câncer de mama para os pulmões. Além disso, como tem sido reportado na literatura, as técnicas cirúrgicas de transplante ortotópico apresentam limitações, sendo um procedimento altamente complicado e invasivo, um método vagaroso com alto custo, além de causar estresse no animal modelo (BIBBY, 2004). A este respeito, nosso trabalho demonstra um processo de inoculação ortotópica de células TE não cirúrgico e menos invasivo para inocular as células tumorais na glândula mamária, seu sítio primário. Isto facilita o monitoramento do perfil proliferativo e representa um ganho em relação à inoculação ortotópica cirúrgica, além de permitir avaliação clínica e produção de imagens, também colaborando na detecção do tumor de mama primário, estagiamento de linfonodos, avaliação da resposta ao tratamento e detecção de doença recorrente e metastática. Além disso, o protocolo desenvolvido, em que é sugerida a inoculação de TE na $4^{\mathrm{a}}$ ou $5^{\mathrm{a}}$ glândula, facilita o procedimento de inoculação, evitando a ocorrência de metástase pela passagem de agulha com bevel ou transfixação para sítios anatômicos não desejados, como músculo, tecido gorduroso e vísceras da cavidade abdominal, reduzindo o desconforto dos animais durante os exames clínicos.

A avaliação do perfil proliferativo do tumor de Ehrlich torna possível determinar a evolução deste tipo de tumor em suas diferentes formas (células frescas e congeladas), assim como sua curva de crescimento. O procedimento realizado com células frescas permite a instalação de tumor clinicamente detectável a partir de 24 horas, quando na literatura o aparecimento clínico do tumor sólido de Ehrlich só foi relatado a partir de 48 horas (PORTILHO et al., 2011; MIRANDA-VILELA et al., 2011; MIRANDAVILELA et al., 2013; MIRANDA-VILELA et al., 2013; MIRANDA-VILELA et al., 2014) da inoculação ou até mesmo mais tarde, como observado para três dias, (SADEGHIANI et al., 2006), sete dias (KABEL, 2014) e até mesmo 12 dias (ABDELRAHMAN, 2012; KABEL, 2014) após a inoculação ectópica. A detecção clínica do 
tumor experimental em menor tempo é interessante porque, assim como a detecção precoce do câncer minimiza a mortalidade e leva a maior chance de cura (HÖFELMANN et al., 2014; DELMONICO et al., 2015), tumores menores são mais adequados para o estudo de novas terapias.

Células tumorais isoladas foram observadas nos linfonodos cervicais quando o tumor de Ehrlich foi inoculado na língua de camundongo, sugerindo processo metastático (BICALHO et al., 2013). Além disso, muitos tumores humanos e os transplantados em camundongos nude apenas induziram metástases quando ortotopicamente inoculados; se aplicados ectopicamente, frequentemente não metastizam (HOFFMAN, 1999; GLINSKII et al., 2003). O acesso preciso do LNS, como feito neste trabalho, é importante não somente para o estagiamento e prognose, mas também para guiar a seleção do tratamento (LYMAN, et al., 2014; LI et al., 2013), uma vez que a metástase para os linfonodos regionais é uma etapa importante na disseminação do câncer, e frequentemente ocorre em estágio relativamente precoce do desenvolvimento do tumor se comparado com as metástases distantes, tais como as do fígado e pulmão (LI et al., 2013).

O LNS é o primeiro linfonodo a ser atingido pelas células metastáticas vindas do sítio primário do tumor. Metástases para os LNS não são aleatórias, mas seguem sequência de etapas previsíveis. Os linfonodos axilares são os sítios preferidos para a propagação do câncer de mama; o estadiamento axilar é considerado o principal fator prognóstico que permite prever com segurança a identificação de micrometástases quando estas ainda não podem ser detectadas por imagens investigatórias. Por esta razão, é um fator importante na obtenção do prognóstico e na decisão sobre o tratamento a ser adotado (FISHER et al., 1983; LYMAN et al., 2014), tendo o mapeamento linfático uma grande contribuição como uma ferramenta diagnóstica capaz de prover o status dos linfonodos da região (FISHER et al., 1983; MANSEL et al., 2006). Tanto quanto sabemos, observações de micrometástases do tumor de Ehrlich nos LNS ipsilateral (nodo sublíaco direito) e LN contralateral (nodo sublíaco esquerdo) (KAWASHIMA et al., 1964; VAN DEN BROECK et al.. 2006) não haviam ainda sido descritas. Na verdade, na literatura não há relatos de metástases do tumor de Ehrlich e envolvimento de linfonodos. Além disso, para o câncer de mama, a maioria das ocorrências são unilaterais, com incidência maior de tumor no lado esquerdo. Esta predominância no lado esquerdo também ocorre nos casos bilaterais nos quais os tumores desenvolvem primeiro e são maiores na mama esquerda (ROBICHAUX et al., 
2015). Este fato poderia explicar os rápidos depósitos metastáticos no LN contralateral sete dias após a inoculação do tumor. Entretanto, não há evidência de metástases nos órgãos analisados, pelo menos na análise feita até o $21^{\circ}$ dia. Sinais de bioluminiscência de células metastizadas dos linfonodos sublíacos para os linfonodos axilares foram descritos em camundongos mutantes que exibiam linfadenopatia sistêmica de 3 a 9 dias, mas não eram evidentes em outros órgãos até o $14^{\circ}$ dia (LI et al., 2013). Considerando que o modelo de câncer utilizado é imunocompetente e a importância, já discutida acima, da inoculação ortotópica não cirúrgica, maior intervalo de tempo deveria ser esperado para se encontrar metástase nos órgãos.

Tem sido descrito que muitas citocinas inatas têm um papel crucial no controle da progressão do câncer de mama. Embora muita pesquisa tenha focado nas anormalidades genéticas que iniciam e dirigem o câncer, existe no momento forte evidência de que o comportamento das células tumorigênicas é também influenciado por seu microambiente (KORKAYA et al., 2011). Alterações nos níveis de citocinas mediadas direta ou indiretamente pelo tumor são parâmetros importantes que afetam o curso da doença. O sistema imunitário, portanto, pode exercer tanto efeitos inibitórios, quanto estimulatórios nos tumores de mama, e o balanço entre estes efeitos pode influenciar profundamente o crescimento do tumor (KORKAYA et al., 2011).

Em geral, a inoculação ortotópica das células tumorais desencadeou uma polarização na direção de uma resposta pro-inflamatória, porque os níveis de secreção de citocinas Th1 (IL-1 $\beta$ e IL-17) foram significativamente maiores do que os antiinflamatórios Th2 (IL-4). IL-4 foi originalmente descrita como um fator de crescimento da célula $\mathrm{B}$, e sabe-se agora que provê potente atividade anti-tumor contra vários tumores, incluindo o câncer de mama (NAGAI et al., 2000; JIA et al., 2014). Simultaneamente, IL-17 e IL-4 produzidas por linfócitos T CD8+ têm sido implicadas na progressão do tumor de mama por terem sido encontrados nos linfonodos que drenam o tumor em pacientes com câncer de mama.

De forma similar, os níveis de secreção de IL-17 aparecem aumentados em pacientes com câncer de mama, o que foi associado com a agressividade da progressão do tumor (BENEVIDES et al., 2013). Também em modelos murinos de tumor de mama, a produção de IL-17 foi descrita como importante marcador da progressão tumoral (ZHANG et al, 2014). Du e cols. (2012) (DU et al., 2012) mostraram que a 
injeção de IL-17 recombinante em camundongos portando tumores 4T1 resultou no aumento do volume do tumor e da densidade da microvasculatura.

A citocina pro-inflamatória IL-1 $\beta$ é também relacionada com a progressão tumoral e predominantemente responsável pelo potencial metastático dos tumores (SAIJO et al., 2002; VORONOV et al., 2003). No presente trabalho, a inoculação do tumor ortotópico desencadeou quantidades significativas de IL-1 $\beta$, o que pode ser relacionado com a geração de metástases nos camundongos analisados.

Por sua vez, a IL-12 é uma citocina pleiotrópica também conhecida como fator estimulatório de células natural killer (NK) ou fator de maturação de linfócitos citotóxicos. IL-12 é um fator essencial para o início da imunidade celular com múltiplos efeitos nas células T e NK (RAO et al., 2006), duas importantes células anti-tumor. Em nossos experimentos, nem as células frescas, nem as congeladas induziram níveis detectáveis de IL-12 após inoculação ortotópica, o que poderia ser esperado desde que esta citocina é produzida principalmente por monócitos e macrófagos.

Em síntese, nosso estudo indica que com a inoculação ortotópica do tumor de Ehrlich, há marcante invasão de estruturas mamárias do hospedeiro, derme e musculatura associada com a invasão da vasculatura linfática nessas áreas. De importância, micrometástases foram vistas frequentemente no LNS e linfonodo contralateral. A série de achados indica que a inoculação ortotópica no microambiente é crítica para interações celulares e subsequente desenvolvimento do câncer e estudos da metástase. Neste sentido, o conhecimento anatômico e fisiológico das glândulas mamárias e da rede ductal favorece os estudos, diagnóstico e terapias relacionadas como câncer de mama e a metástase. Além disso, este estudo fornece suporte anatômico para a compreensão da distribuição linfática no processo de câncer.

Na continuação deste trabalho (parte 2), o modelo desenvolvido foi usado em novos testes para tratamento do câncer. 
ETAPA 2: MAGNETOHIPERTERMIA E QUIMIOTERAPIA PARA TRATAMENTO DE ADENOCARCINOMA MAMÁRIO DE EHRLICH EM CAMUNDONGO SWISS: USO DE NANOPARTÍCULAS DE MAGHEMITA RECOBERTAS COM Citrato E NANOCÁPSUlas de POLIETILENO GLICOL CONTENDO SELOL

\section{INTRODUÇÃO}

Nanotecnologia pode ser definida como o design intencional para a caracterização, produção e aplicações de materiais, estruturas, dispositivos e sistemas em que pelo menos uma das dimensões está na ordem de grandeza nanométrica (1 a 100 $\left.\mathrm{nm}, 1 \times 10^{-9}\right)$, em que um nanômetro $(\mathrm{nm})$ equivale à bilionésima parte do metro. (O prefixo "nano" deriva da palavra grega "anão"). A Nanobiotecnologia é um ramo da Nanotecnologia voltado às aplicações biológicas e médicas (MOGHIMI et al., 2005; LONDON, 2007; SAHOO et al., 2007).

$\mathrm{Na}$ área biomédica, a Nanobiotecnologia tem o potencial de produzir avanços importantes no diagnóstico e na terapêutica do câncer. No diagnóstico por imagem, por exemplo, a imunolocalização de células tumorais, mediada por nanopartículas superparamagnéticas (NPM), permite a detecção precoce de tumores e micrometástases por imagem de ressonância magnética nuclear (RMN). A impregnação de células tumorais com NPM também pode facilitar a erradicação de tumores, mediante a lise celular focal dirigida pelo processo de magnetohipertermia (MHT) (PAVON e OKAMOTO, 2007).

O grupo de Nanobiotecnologia da UnB já investigou diversos tipos de fluidos magnéticos (FM) contendo NPM recobertas com várias coberturas estabilizantes: citrato (BRUGIN, 2007), polifosfato (PORTILHO, 2007), ácido poliaspártico (SADEGHIANI, 2008), albumina bovina (LACAVA, 2009), albumina (ESTEVANATO et al., 2011), dextrana (ESTEVANATO et al., 2012), ácido dimercapto-succínico (CAMPOS DA PAZ, 2012). 
Os FM baseados em NPM recobertas com dextrana ou com citrato, por exemplo, já foram estudados quanto às suas propriedades físicas e biológicas, tendo sido mostrado que são eficazes em várias aplicações, principalmente por demonstrarem alta biocompatibilidade in vitro e in vivo, quando expostos a sistemas biológicos (LACAVA et al., 2004, BRUGIN, 2007; MIRANDA-VILELA, 2013).

Entre as terapias convencionais para o tratamento do câncer, inclusive o de mama, estão a quimioterapia, considerada um tratamento sistêmico, a radioterapia e a cirurgia, consideradas tratamentos locais. Esses tratamentos podem ser usados isoladamente ou em terapia combinada (DINIZ, 2008).

A maioria dos agentes antineoplásicos de uso corrente tem pouca ou nenhuma especificidade para as células tumorais (MADER, 2006; SCHWEIZER, 2009; TESTA, 2010). Como consequência, a utilização desse tratamento tradicional, agride as células normais, principalmente as que possuem características semelhantes às tumorais (DINIZ, 2008). Os principais efeitos adversos da quimioterapia são as toxicidades hematológicas, gastrintestinais, cardíacas, pulmonares, renais e dermatológicas, além de disfunções reprodutivas, alterações metabólicas, reações alérgicas e anafilaxia, os quais representam uma reação alérgica sistêmica, severa e rápida. Embora bem estabelecida e com importantes sucessos conseguidos nos últimos anos, a quimioterapia permanece como objeto de investigações que visam ampliar e otimizar seus resultados (DINIZ, 2008). Outrossim, o uso de um único fármaco quimioterápico antineoplásico pode apresentar limitações no tratamento de tumores, como desenvolvimento de resistência ao quimioterápico antineoplásico e alta toxicidade. A terapia combinada com dois ou mais fármacos, ou ainda de um fármaco com outra modalidade terapêutica, como a radioterapia ou a imunoterapia, poderia ser empregada para minimizar estas limitações (WANG et al., 2011).

As terapias realizadas por radioterapia também apresentam efeitos adversos. Os efeitos imediatos são observados nos tecidos que apresentam maior capacidade proliferativa, como as gônadas, a epiderme, as mucosas dos tratos digestivo e genitourinário e a medula óssea. Manifestam-se clinicamente por anovulação ou azoospermia, epitelites, mucosites e mielodepressão (leucopenia e plaquetopenia). Já os efeitos tardios que se manifestam por atrofias e fibroses, são raros e ocorrem quando as doses de tolerância dos tecidos normais são ultrapassadas. As alterações de caráter genético e o desenvolvimento de outros tumores malignos são raramente observados (INCA, 2011).

Visando minimizar os efeitos tóxicos e sistêmicos decorrentes dos tratamentos 
de neoplasias, pesquisas têm se empenhado em propor novas alternativas, entre as quais, as que empregam NPM. A introdução de NPM na área médica gerou esperanças significativas para o diagnóstico precoce e tratamento de doenças severas, como o câncer (LAURENT e MORTEZA, 2011). As NPM com potencialidade de aplicação em biomedicina baseiam-se principalmente em óxidos de ferro, geralmente magnetita ou maghemita $\left(\mathrm{Fe}_{3} \mathrm{O}_{4}\right)$. Além de apresentarem biocompatibilidade adequada, têm comportamento superparamagnético à temperatura ambiente, o que significa que só têm comportamento magnético quando expostas à ação de um campo magnético (BECK, 2011).

O FM é um colóide constituído de NPM suspensas em uma matriz líquida não magnética. A estabilidade coloidal é mantida pelo controle do diâmetro na NPM, pela temperatura, através das interações partícula-partícula e da interação entre as partículas e o líquido carreador, para não ocorrer separação de fases no sistema, seguida de precipitação (FIGUEIREDO, 2009).

As NPM devem ter a capacidade de cruzar a barreira endotelial e se acumular especificamente nas células-alvo, sem causar dano às células normais. Essas características podem ser atingidas por meio da cobertura das NPM com um material biologicamente ativo como camada estabilizante (íons, nucleotídeos, peptídeos, polissacarídeos, vitaminas, antibióticos ou anticorpos), do controle de seus parâmetros físicos (tamanho da partícula e suscetibilidade magnética da solução) e do conhecimento do seu comportamento no organismo (LACAVA, 2006; PAVON e OKАMOTO, 2007).

São muitas as possíveis aplicações biomédicas das NPM que abrangem desde ser agente de contraste para imagem por ressonância magnética (IRM), a separação de células e biomoléculas, engenharia tecidual, sistemas de vetorização de fármacos e DNA a alvos específicos, até o tratamento de tumores por hipertermia, conhecido como magnetohipertermia (MHT) ou magnetotermocitólise, quando se tem a lise de células tumorais (BRAZ, 2011; PORTILHO et al., 2011).

\section{Magnetohipertermia}

A hipertermia é empregada na área biomédica como um procedimento terapêutico capaz de proporcionar aquecimento de tecido alvo acima dos limites de temperatura fisiológica normal. Isso resulta na alteração da fisiologia, do tecido, 
promovendo assim a morte das células tumorais por necrose ou apoptose (TARTAJ et al., 2003, KUMAR, 2011).

A MHT requer a presença de NPM no tecido alvo e aquecimento seletivo dessa área, obtido por meio da exposição das NPM a um campo oscilante de alta frequência gerado por corrente alternada, com intensidade e frequência adequadas e suficientes para causar aquecimento $\left(41-42^{0} \mathrm{C}\right)$ das nanoestruturas (PAVON e OKAMOTO, 2007; VERDE, 2012 ). O princípio físico pelo qual o material magnético pode ser aquecido pela ação de um campo magnético alternado externo está relacionado aos processos de perda de energia que ocorrem durante a reorientação da magnetização de materiais magnéticos com baixa condutividade elétrica (TARTAJ et al., 2003). O calor gerado eleva a temperatura local a $41^{\circ} \mathrm{C}-42^{\circ} \mathrm{C}$ e tem o efeito de destruir seletivamente as células tumorais, uma vez que essas são menos resistentes a aumentos bruscos de temperatura do que as células normais circunvizinhas (TARTAJ et al., 2003; PAVON e OKAMOTO, 2007).

É possível ainda associar a MHT a outras modalidades de tratamento de câncer, ou seja, usá-la em uma forma combinada e adjuvante em terapias estabelecidas, tais como a quimioterapia ou a radioterapia, sobretudo para melhorar a eficácia dos fármacos antineoplásicos sem aumentar o seu potencial citotóxico, ou para aumento da resposta clínica na radioterapia, imunoterapia e na terapia gênica ( HILDEBRANDT et al, 2002; DURAN et al., 2006). A entrega específica de fármacos, combinada com a MHT, pode apresentar resultados sinérgicos e assim representar uma terapia promissora. Nesse cenário, a hipertermia aparece no rol de tratamentos da "American Cancer Society" considerados as mais poderosas modalidades terapêuticas para melhorar a evolução de pacientes com câncer.

\section{Selol}

O Selol tem como base o selênio ( $\mathrm{Se})(\mathrm{SeO}(\mathrm{OH}) 2)$, um metalóide descoberto, isolado e identificado como elemento essencial para os organismos na década de 1817 , pelo químico sueco Jöns Jacob Berzelius (1779-1848) (FOSTER e SUMAR 1997, BARCELOUX 1999). Amplamente distribuído no ambiente (águas, solo e ar), embora geralmente em concentrações muito baixas (menos que $0,1 \mu \mathrm{g} / \mathrm{g}$ ), o selênio e seus compostos podem ter aplicações tecnológicas gerais, tanto nos aparelhos eletrônicos para produção de semicondutores, fotocélulas e retificadores, como nas indústrias: a) 
mecânica, para a obtenção de aço de alto grau; b) química, como catalisadores; c) de borracha, para aceleração da vulcanização; d) do vidro, na produção de copos, espelhos, óculos, entre outros. Além dessas aplicações, ele é bastante utilizado na medicina veterinária para tratamento de doenças correlacionas à sua carência. Na agricultura, os organocompostos de selênio são usados como bactericidas, fungicidas e herbicidas (BEM, 1981).

O seu papel biológico é bem estabelecido na sequência da descoberta de que ele corresponde a um componente estrutural do centro ativo de várias enzimas. Dessa forma o selênio encontra-se presente como selenocisteína em pelo menos 30 proteínas, como a glutationa peroxidase, selenoproteína $\mathrm{P}$, selenoproteína $\mathrm{W}$, do tipo iodotironinadesiodase (ZACHARA, 1992).

Como bioelemento (elemento traço), o selênio é crucial para o funcionamento do organismo. Doenças relacionadas à carência do selênio (síndrome da deficiência de selênio) em animais e em humanos foram caracterizadas pela primeira vez em 1950, estando associadas com a predisposição para certas condições patológicas, tais como câncer (BECKETT e ARTHUR, 2005; IRONS et al., 2006), aumento significativo do colesterol plasmático entre outras (DUTRA-DE-OLIVEIRA e MARCHINI, 1998).

Os grãos são boas fontes de selênio, da mesma forma que pode ser encontrado em carnes, vegetais, frutos do mar e nas castanhas, entre outros (NAFISI et al., 2012). Entretanto, a quantidade de selênio contida em alimentos, água e ar refletem a concentração do mesmo no solo, e consequentemente, é desuniforme em alimentos provenientes de regiões diferentes (OLIVEIRA, 2006). Como complemento alimentar e sua importante ação antioxidante, funciona como agente antimutagênico, prevenindo modificações malignas de células normais. $\mathrm{O}$ efeito protetor do selênio está associado à presença na glutationa peroxidase e na tireodoxina redutase, enzimas protetoras do DNA e outros componentes celulares do dano oxidativo (BASKETT et al., 1995; KAMAT e LAMM, 1999; SCHRAUZER, 2000; TRUEBA et al., 2004). Todavia, o excesso de consumo do selênio é tóxico, o que poderá reverter sua ação protetora, gerar danos ao DNA e induzir o processo carcinogênico (NOVOTNY et al., 2010; LUO et al., 2012).

O Selol é um composto de selenitotriglicerídeos, obtido por modificação química a partir do óleo de girassol que contém selênio no estado de oxidação +4 , sintetizado e patenteado pelo Departamento de Análises de Drogas de Varsóvia, Polônia 
(SUCHOCKI, 2007; GRABOWSKI, 1999; JASTRZĘBSKI et al., 1995). Estudos do perfil da biodistribuição do Selol foram realizados em camundongos e ratos. Quando administrado por via oral, subcutânea e por via intraperitoneal, as concentrações mais elevadas foram encontradas na glândula suprarrenal, testículos, epidídimo e cérebro, enquanto as mais baixas foram encontradas no cerebelo, fígado, rins, pulmões e baço, sendo a menor concentração a do coração. Em estudos de toxicidade realizadas determinou-se DL50 (dose letal para 50\% dos animais) de $100 \mathrm{mg}$ Se/kg após a administração oral de Selol (JASTRZĘBSKI et al.,1995 ; Z. JASTRZEBSKI, 1997).

A utilização do Selol está bem descrita na literatura: 1) em formulação de nanocápsulas de Selol para testar eficácia contra as células de adenocarcinoma de pulmão (A549) (de SOUZA et al, 2014); 2) em causar estresse oxidativo em células da próstata, tanto normais (PNT1A), como malignas (LNCaP), devido a alterações da expressão de genes (KSIAZEK, 2013); 3) na investigação de sistemas nanoestruturados para o tratamento de câncer de mama, em que representou agente potencializador da eficácia terapêutica de quimioterápicos antineoplásicos (ESTEVANATO, 2012); 4) em atividade anticâncer quimiopreventiva e na capacidade para inibir a proliferação celular e induzir a apoptose (SUCHOCKI et al, 2007); 5) na potencialização da inibição do crescimento 4-hidroxitamoxifeno $\left(10^{-7} \mathrm{~mol} / \mathrm{L}\right)$ em linhagens celulares de câncer sensíveis ao tamoxifeno (SHAH, 2005). 


\section{JUSTIFICATIVA}

A quimioterapia, embora uma abordagem terapêutica muito comum, apresenta baixa eficácia quando o câncer não é tratado em estágios iniciais. Via de regra, os quimioterápicos antineoplásicos não são específicos, agindo tanto em células tumorais quanto em normais, o que é responsável pelos efeitos adversos observados. Por esta razão, o desenvolvimento de estratégias terapêuticas, tais como sistemas de entrega de drogas, que possam minimizar os efeitos tóxicos dos tratamentos e melhorar o diagnóstico por imagens convencionais, é de grande interesse e importância para a pesquisa contra o câncer.

As NPM, com suas dimensões reduzidas e possibilidade de serem funcionalizadas com ligantes específicos, têm facilidade para transitar em diversos compartimentos do organismo e de se acumular preferencialmente em tecidos tumorais. Esses fatos, aliados à incidência crescente do câncer, justificam e estimulam a avaliação da eficácia da terapia combinada com a magnetohipertermia, usando nanopartículas de maghemita recobertas com citrato, e a quimioterapia, mediada por nanocápulas de Selol, para o tratamento do adenocarcinoma mamário de Ehrlich, obtido por inoculação ortotópica em camundongo Swiss, um modelo recentemente desenvolvido e descrito na Etapa 1 do presente trabalho, com perspectivas futuras para aplicação médica. 


\section{OBJETIVO GERAL}

Avaliar a eficácia de duas terapias combinadas, a magnetohipertermia, promovida por nanopartículas de maghemita recobertas com citrato expostas a campo magnético AC e a quimioterapia, mediada por nanocápsulas contendo Selol, compostos ricos em selênio em modelo ortotópico de câncer mamário.

\section{Objetivos Específicos}

- Caracterizar o NPcit e ou NPsel por Microscópio Eletrônico de Transmissão (MET), Microscópio Eletrônico de Varredura (MEV), espalhamento de luz dinâmica, medida de potencial zeta e termometria;

- Investigar a distribuição da NPcit na região tumoral por MCT e histologia;

- Determinar os efeitos dos tratamentos com NPcit e NPsel em camundongos por testes hematológicos, bioquímicos, genotoxicidade e histológicos;

- Avaliar os efeitos antitumorais do tratamento com magnetohipertermia usando a amostra NPcit e quimioterapia com Selol, usando a amostra NPsel, estabelecendo as condições experimentais que levam à cura;

- Avaliar o status nodal por meio do mapeamento linfático;

- Determinar a porcentagem de micrometástases nos linfonodos sentinelas (LNS) e linfonodos contralaterais (LNCL);

- Avaliar a taxa de sobrevida dos animais com TE. 


\section{MATERIAIS E MÉTODOS}

Para avaliar a eficácia de duas terapias, magnetohipertermia (MHT) e quimioterapia no modelo de câncer mamário ortotópico, recentemente desenvolvido (Etapa 1), foram utilizados dois protocolos terapêuticos distintos, denominados Tratamento 1 e Tratamento 2, os quais empregavam equipamentos de MHT diferentes, designados como equipamento Magnetherm (Figura 21) e equipamento CMagMHG (equipamento campo magnético Maria Helena Guedes) (Figura 22). Em ambos os tratamentos, após a inoculação ortotópica de células tumorais frescas, foram utilizadas, para a MHT, nanopartículas de maghemita recobertas com citrato (NPcit) e, para a quimioterapia, nanocápsulas contendo Selol (NPsel), (compostos ricos em selênio). No tratamento 1 foi utilizado Doxorrubicina (DXR) como controle positivo e no tratamento 2, Paclitaxel, ambos administrados por via intraperitoneal.

\section{Equipamentos para magnetohipertermia (MHT)}

\section{Equipamento gerador de campo magnético AC (tratamento 1) -} equipamento Magnetherm.

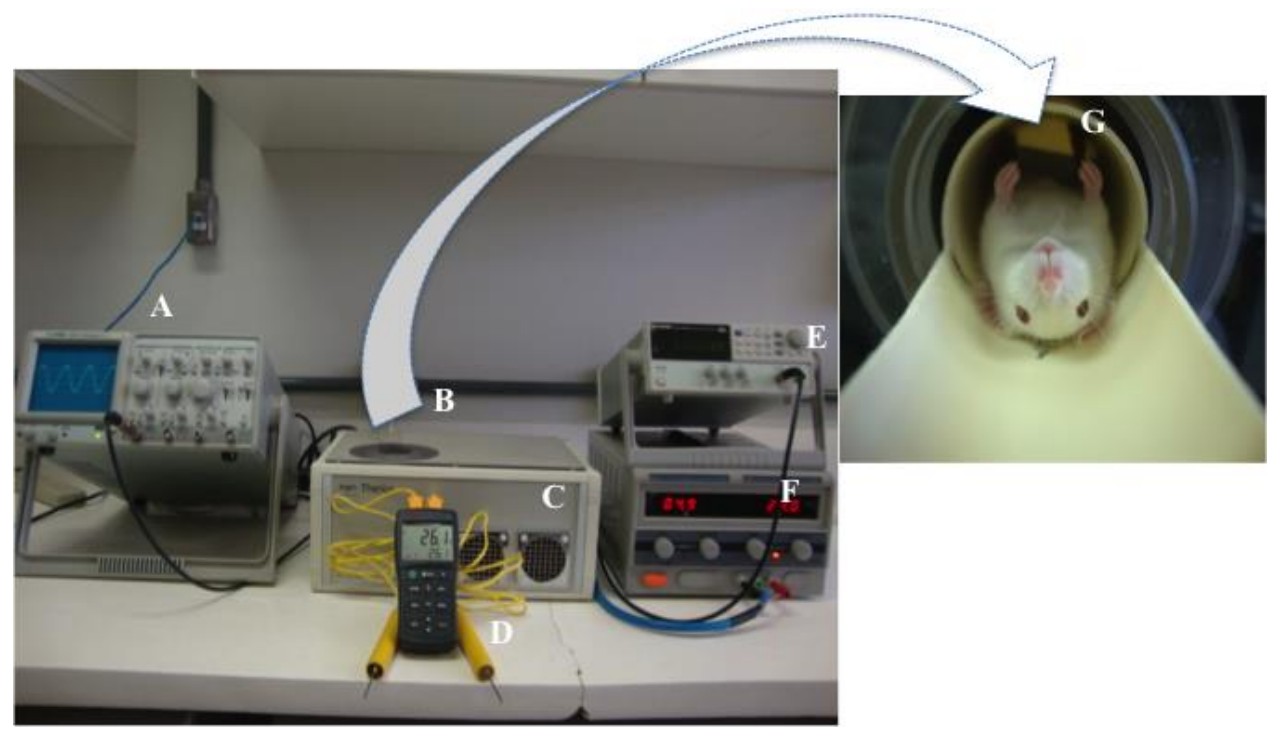

Figura 18: Equipamento gerador de campo magnético de frequência alternada (MagneTherm, NanoTherics). A- Osciloscópio; B - bobina geradora do campo magnético; CTermômetro digital de múltiplos canais; D e E- Fonte de tensão; e G detalhe do animal sob campo magnético AC. 
Equipamento gerador de campo magnético AC (tratamento 2) equipamento CMagMHG.

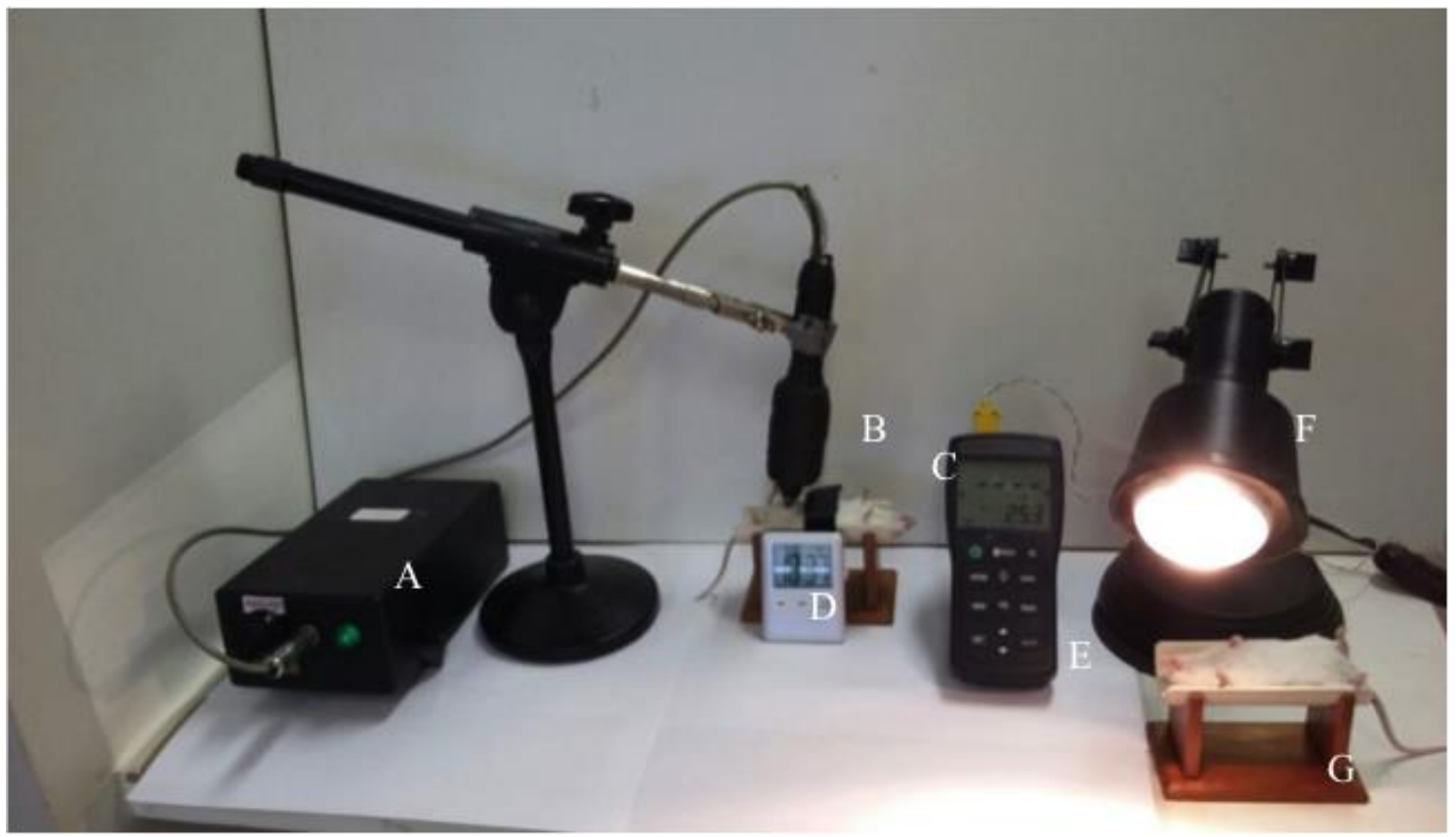

Figura 19: A) equipamento gerador de campo eletromagnético de frequência alternada; B) Solenoide com haste móvel; C) Animal se submetendo ao campo magnético; D) Cronógrafo; E) Termômetro digital de múltiplos canais; F) Fonte de calor e G) Animal em recuperação após exposição ao campo magnético AC (pós-anestésico).

\section{Amostras Nanoestruturadas}

Nanopartículas magnéticas recobertas com citrato (NPcit) (Tratamentos 1 e 2)

O FM baseado em NPM de maghemita $\left(\gamma-\mathrm{Fe}_{2} \mathrm{O}_{3}\right)$ recobertas com citrato foi gentilmente fornecido pela Profa. Emilia Celma de Oliveira Lima, do Instituto de Química (IQ) da Universidade Federal de Goiânia (UFG), nomeado NPcit. As NPM foram sintetizadas por co-precipitação de $\mathrm{Fe}$ (II) e Fe (III) em meio alcalino e estabilizadas pela adição de citrato à reação.

Nanocápsulas de PLGA contendo compostos ricos em selênio (Tratamentos 1 e 2) 
Para a quimioterapia, a amostra utilizada no estudo, designada NPsel, era constituída por nanocápsulas de ácido poli láctico-co-glicólico (PLGA), contendo 10 $\mathrm{mg} / \mathrm{mL}$ de Selol 5\%, o que equivale a $500 \mu \mathrm{g}$ de selênio. NPsel foi desenvolvida com o apoio da Dra. Jaqueline R. Silva e da doutoranda Ana Lígia Câmara, ambas do Laboratório de Nanobiotecnologia do Departamento de Genética e Morfologia do Instituto de Ciências Biológicas da Universidade de Brasília (UnB). O Selol utilizado foi sintetizado e patenteado (GRABOWSKI, 1999 ) pelos departamentos de Análise de Drogas e de Química Farmacêutica, da Universidade de Medicina de Varsóvia, Polônia, e gentilmente cedido para este estudo.

As nanocápsulas contendo Selol no seu núcleo oleoso NPsel, foram preparadas segundo Fessi e colaboradores (1988), pelo método de deposição interfacial e evaporação de solvente. A fase oleosa orgânica foi constituída de PGA, fosfatilcolina de soja, óleo de soja e Selol; como solventes orgânicos foram utilizados acetona e metanol.

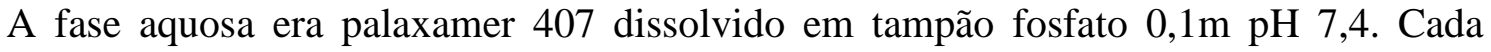
constituinte foi dissolvido separadamente, e após total dissolução a fase oleosa foi gotejada na fase aquosa, mantida sob agitação magnética por 10 minutos a temperatura ambiente. Após este tempo a mistura foi levada ao rota evaporador, para evaporação do solvente e concentração das nanocápsulas (Anexo 6).

\section{Caracterização das Nanoestruturas}

\section{Caracterização das amostras por Microscopia Eletrônica de Transmissão}

Para realizar a caracterização por Microscopia Eletrônica de Transmissão (MET), as amostras NPsel e NPcit foram diluídas em água ultrapura deionizada (1:500) (sistema Milli- $\mathrm{Q}^{\circledR}$, Millipore Corporation ${ }^{\circledR}$ ). Em seguida, foram depositadas em telinhas de malha de cobre de 300 meshs, recobertas com substrato (filme de apoio) Formvar ${ }^{\circledR}$ (formal de polivinil) a 0,4\%. Após secar por 24 horas, as amostras foram contrastadas por quarenta e cinco minutos com vapor de Tetróxido de Ósmio $\left(\mathrm{OsO}_{4}\right)$ a $1 \%$, e, em seguida analisadas e fotomicrografadas em Microscopia Eletrônica de Transmissão (JEOL 1011) no Laboratório de Microscopia Eletrônica, CEL, IB, Universidade de Brasília. O diâmetro médio da amostra avaliada por MET foi obtido por análise em 
computador, utilizando-se o software Image-ProPLus versão 5.1; a distribuição das partículas foi conseguida utilizando-se o melhor ajuste log normal.

\section{Caracterização das amostras por Microscopia Eletrônica de Varredura (MEV)}

Para a caracterização de NPsel por MEV foi utilizado microscópio eletrônico de varredura modelo JEOL JSM-7001F, do Laboratório de Microscopia Eletrônica da Universidade de Brasília. Após a secagem, as nanocápsulas (NPsel) foram aderidas em fita dupla-face de carbono, coladas no porta-amostra e após ter retirado o excesso por fluxo de ar, receberam revestimento por aspersão de filme de ouro (metalização da amostra).

\section{Determinação do tamanho hidrodinâmico e potencial Zeta das amostras por Espalhamento de Luz Dinâmica}

As amostras NPsel e NPcit foram caracterizadas quanto ao tamanho hidrodinâmico e à carga de superfície por Espalhamento de Luz Dinâmica (DLS Dynamics Light Scattering) no equipamento Zetasizer NanoZS (Malvern). Para tanto, as amostras foram diluídas $(1: 100)$ em água deionizada purificada em sistema Milli- ${ }^{\circledR}$ (Millipore Corporation ${ }^{\circledR}$ ). As medições foram realizadas em triplicata, a $25^{\circ} \mathrm{C}$, com um ângulo fixo de detecção de $173^{\circ} \mathrm{C}$.

\section{Caracterização de NPcit por Difração de Raios-X}

$\mathrm{Na}$ caracterização de NPcit por difração de raios X (DRX), a amostra foi desidratada em ambiente de baixo vácuo e armazenada em forma de pó, sem contato atmosférico. As medidas foram realizadas em um difratômetro Shimadzu modelo DOX6000, com fonte de cobre com linha em CuKa de $\lambda$ 1,54 Angstrom em $40 \mathrm{KV}$ e $20 \mathrm{~mA}$.

\section{Termometria in vitro}

Para verificar a capacidade de aquecimento de NPcit, foram feitos testes de MHT in vitro, com NPcit em quatro diferentes volumes de $(1000 \mu \mathrm{L}, 110 \mu \mathrm{L}, 105 \mu \mathrm{L}$ e $100 \mu \mathrm{L})$ e o equipamento Magnetherm-Nanotherics operando com Capacitor (Bobina) B2 17 voltas, frequência $330 \mathrm{kHz}, 250 \mathrm{~V}$ e 4.9 A (Figura 21). Para a termometria in vitro, os registros e aferições das temperaturas, foi utilizado o termógrafo FlIR 
SySTEMS $^{\circledR}, 2008$, Flir Infra CAM SD, e para os acompanhamentos das curvas de aquecimentos, um termômetro digital MINIPA ${ }^{\circledR} 2$ canais c/rs-232 mt-525. A

\section{Controle de qualidade do ativo (Selol)}

Uma alíquota de $1 \mathrm{~mL}$ de Selol a 5\% foi transferida para um microtubo de 1,5 $\mathrm{mL}$ protegido com papel alumínio, de forma asséptica, encaminhado ao laboratório de Microbiologia de Clínica da Faculdade Lurdes Santana (LS) Brasília (DF).

Foram preparadas placas com meio de culturas, nas seguintes especificações:

- 2 placas de meio ágar sangue (Meio enriquecido, permite o crescimento da todas as formas de microrganismos);

- 2 placas de meio ágar Mac Conkey (Meio seletivo, permite o crescimento de bactérias Gram negativas e inibe o crescimento de gram positivas e fungos);

- 2 placas de meio ágar Sabouraud;

- 2 placas de meio BHI (brain heart infusion) (permite o crescimento da maioria dos microrganismos).

Em uma capela de fluxo laminar tipo II, foi realizado o semeio do produto pelo método de esgotamento em estrias, com uma alça bacteriológica descartável calibrada em $10 \mu \mathrm{L}$. Após os semeios em duplicatas, as placas foram incubadas em estufa de bacteriologia a $36,5^{\circ} \mathrm{C}$, temperatura ideal para o crescimento da maioria dos microrganismos contaminantes. As leituras das placas foram realizadas em fluxo laminar com a incidência de luz sobre o meio, nos tempos de 24, 48 e 72 horas.

\section{Distribuição e parâmetros clínicos (Tratamento 2)}

A distribuição das NPM de NPcit foi avaliada por meio de microtomografia computadorizada (MCT) (PANKHURST et al., 2003; SANTANA, 2005; COLOMBO et al., 2012) e por análise morfológica. A MCT foi realizada como descrito anteriormente, na Etapa 1. Para análise histológica foram usados os órgãos mama com tumor, mama contralateral ( $5^{\mathrm{a}}$ glândula mamária esquerda), fígado, baço, rins e cérebro, com o corante vermelho rápido nuclear associado ao método de coloração de Perls hematoxilina-eosina, conforme protocolo de fixação e plano de cortes descritos na Etapa 1. 
Os demais parâmetros clínicos dos grupos foram analisados de acordo com o Guia para a Condução de Estudos não Clínicos de Toxicologia e Segurança Farmacológica Necessários ao Desenvolvimento de Medicamentos (ANVISA, 2013).

Os animais, massa corporal, idade, aquisição, alojamento e autorização do Comitê de Ética tinham as mesmas especificações dos da etapa 1. Também foram usados os protocolos da Etapa 1 para os procedimentos de anestesia, monitoramento do desenvolvimento do tumor, efeito da terapêutica, análise histopatológica, MCT e avaliação dos níveis de interleucinas.

\section{Tratamento (1) equipamento (Magnethterm) e Tratamento (2) equipamento (CMagMHG)}

Foram averiguados o comportamento, as reações e o desenvolvimento ponderal dos animais de os grupos, em intervalos de 24 horas a partir da inoculação das células tumorais até a eutanásia. Para esses procedimentos, foram utilizados análise clínica e, para as aferições, paquímetro e/ou balança digital de precisão. Nos grupos tumorais foram inoculados, na $5^{\mathrm{a}}$ glândula mamária direita, $100 \mu \mathrm{L}$ contendo $1 \times 10^{6}$ de células tumorais de Ehrlich frescas, com viabilidade maior que 95\%. Nos grupos de tratamento foram injetados NPsel e/ou NPcit intratumoralmente. Esses procedimentos tiveram início 24h após a inoculação de células TE, momento em que o tumor apresentava tamanho adequado $(10 \mathrm{~nm})$ para o tratamento, conforme protocolo estabelecido na Etapa 1.

\section{Tratamento 1, equipamento Magnetherm}

Para o tratamento 1 (Tabela 3), foi utilizado o equipamento MagneTherm NanoTherics ${ }^{\circledR}$, adquirido comercialmente, e constituído por um conjunto de um gerador de campo magnético de frequência alternada; um osciloscópio; uma bobina geradora do campo magnético; uma fonte de tensão; um termômetro digital de múltiplos canais e um cronógrafo digital (Figura 21).

Nos testes, os animais foram expostos a campo magnético de corrente alternada com capacitor (Bobina) B2 17 voltas, frequência $330 \mathrm{kHz}, 250 \mathrm{~V}$ e 4.9, amplitude 40 Oe de campo magnético oscilando em $1 \mathrm{Mhz}$, por 30 minutos, nos dias de injeção do NPcit e nos dias posteriores, uma vez a cada 24 horas, totalizando 7 exposições para o 
grupo de tratamento por 1 semana (Tratamento 1a) ou 14 exposições ao campo para o grupo de tratamento por 2 semanas (Tratamento 1b) (Tabela 3).

Para avaliar a terapia proposta, foram utilizados 54 animais, distribuídos randomicamente em dois grupos de Tratamento, $1 \mathrm{a}$ e $1 \mathrm{~b}(\mathrm{n}=3)$ :

- Grupo controle negativo: injeção de $100 \mu \mathrm{L}$ de solução salina estéril $0,9 \%$ no sítio de inoculação das células tumorais;

Todos os demais grupos foram inoculados com $100 \mu \mathrm{L}$ de células tumorais frescas $=\mathrm{TE}$

- grupo controle tumor: TE

- grupo controle positivo: TE + injeção de Doxorrubicina ip na dose de $40 \mathrm{mg} / \mathrm{Kg}$;

- grupo controle NPcit: TE + injeção de $110 \mu \mathrm{L}$ de NPcit;

- grupo controle CMag: TE + exposição a campo magnético;

- grupo quimioterapia NPsel: TE + injeção de $100 \mu \mathrm{L}$ de NPsel;

- grupo magnetohipertermia MHT: TE + NPcit + CMag;

- grupo controle quimioterapia e campo AC: TE + CMag + NPsel;

- grupo terapia combinada: TE + MHT (NPcit+CMag) + NPsel.

Tabela 3: Tratamento 1, equipamento Magnetherm.

\begin{tabular}{|l|l|}
\hline \multicolumn{2}{|c|}{ 1a (1 semana de tratamento) } \\
\hline NPcit & Única aplicação \\
\hline NPsel & Única aplicação \\
\hline CMag & 7 exposições \\
\hline \multicolumn{2}{|c|}{ 1b (2 semanas de tratamento) } \\
\hline NPcit & Única aplicação \\
\hline NPsel & Única aplicação \\
\hline CA & 14 exposições \\
\hline Obs.: Doxorrubicina (ip) única aplicação para 1a e 1b. \\
\hline
\end{tabular}

NPcit = Nanopartículas magnéticas recobertas com citrato; nanocápsulas de PLGA contendo Selol; NPsel= CMag = campo magnético AC. 


\section{Tratamento 2, equipamento CMagMHG}

Após obter os resultados do Tratamento 1, decidiu-se pela busca de estratégias mais eficazes para o câncer mamário. Para o Tratamento 2 equipamento CMag, foi utilizado um equipamento gerador de campo eletromagnético de frequência alternada operado por radiofrequência (Figura 22) (Patente: PI 0204433-1), desenvolvido por nosso grupo de pesquisa, constituído por um solenoide com haste móvel, um cronógrafo e um termômetro digital de múltiplos canais obtidos comercialmente. Os animais foram submetidos à ação deste equipamento operando a uma radiofrequência de $1 \mathrm{MHz}$ em uma amplitude de 40 Oe e com intensidade de corrente elétrica de 1 A/m (GUEDES et al. 2004; PORTILHO, 2011), por 30 minutos, nos dias de injeção do NPcit e no dia posterior, uma vez a cada 24 horas, totalizando 7 exposições ao campo para o grupo de tratamento por 1 semanas (Tratamento 2a) ou 14 exposições para o grupo de tratamento por 2 semanas (Tratamento $2 b$ ).

Nesse experimento foram empregados 60 animais randomizados em seis grupos (controles e tratamentos), distribuídos em dois subgrupos com exposições; (a) uma semana; (b) duas semanas, ambos grupos coletados (eutanásia) uma semana após os tratamentos, assim distribuídos:

- Subgrupo a1 e a2, controles negativos (G0);

- Subgrupos a2 e b2, controle tumor (G1);

- Subgrupos a3 e b3, TE + CMag + NPcit (MHT) (G2);

- Subgrupos a4 e b4, NPsel (G3);

- Subgrupos a5 e b5, de terapia mista TE + CMag + NPcit (MHT) + NPsel (G4);

- Subgrupos a6 e b6, controles tratamentos positivos PTX (Paclitaxel) + TE (G5). Para o subgrupo a6 e b6, o PTX utilizado nos animais dos controles positivos foi solubilizado em etanol $70 \%$ e Cremophor $^{\circledR}$ a $10 \%$, e inoculado por via intraperitoneal na dose de $16 \mathrm{mg} / \mathrm{Kg}$ em única aplicação de $50 \mu \mathrm{L}$ (JANA’TAMSBURY et al., 2004; Eralp et al., 2004). 
Ressaltando que:

- Nos grupos controles tumor foram inoculados $100 \mu \mathrm{L} 1 \times 10^{6}$ células tumorais frescas;

- No inicio e fim dos tratamentos todos os animais foram submetidos a MCT;

- Nos grupos NPcit, NPsel e NPcit +NPsel, foram injetados 110, 80 e $60 \mu \mathrm{L}$ de NPcit a cada semana. A cada 24 horas a parti da primeira aplicação de NPcit houve exposições de 30 minutos ao campo alternado (MHT) dos referidos grupos. 
Tabela 4: Tratamento 2, equipamento CMagMHG

\begin{tabular}{|l|l|}
\hline \multicolumn{2}{|c|}{ 2a (1 semana de tratamento) } \\
\hline NPcit & 3 aplicações \\
\hline NPsel & 3 aplicações \\
\hline CMag & 7 exposições \\
\hline Obs.: Eutanásia após 7 dias \\
\hline \multicolumn{2}{|c|}{ 2b (2 semanas de tratamentos) } \\
\hline NPcit & 6 aplicações \\
\hline NPsel & 6 aplicações \\
\hline CMag & 14 exposições \\
\hline $\begin{array}{l}\text { Obs.: Eutanásia após } 7 \text { dias, Paclitaxel (ip) única } \\
\text { aplicação para 2a e 2b. }\end{array}$ \\
\hline
\end{tabular}

NPcit = Nanopartículas magnéticas recobertas com citrato; nanocápsulas de PLGA contendo Selol; NPsel= CMag = campo magnético AC.

\section{Investigação do processo metastático e identificação dos LNS e LNCL}

A investigação do status nodal foi iniciada com a inoculação de $100 \mu \mathrm{L}$ de células frescas de TE na $5^{\text {a }}$ glândula direita. Para a identificação dos linfonodo sentinela, LNS, (linfonodo subiliaco direito), linfonodo contralateral (linfonodo subiliaco esquerdo) e nas análises de seu acometimento por micrometástases foram injetados, no coxim adiposo (subcutâneo da papila mamária) periaureolar, $15 \mu \mathrm{L}$ de Azul de Tripan a $20 \%$, na $5^{\mathrm{a}}$ glândula mamária direita e o mesmo volume na $5^{\mathrm{a}}$ glândula mamária esquerda (totalizando $30 \mu \mathrm{L}$ ), 12 horas antes da eutanásia. Os órgãos rim, pulmão, fígado e baço também foram alvos de investigação para metástases. Os fragmentos foram fixados, processados e tiveram plano de cortes para inclusão, como descrito nos protocolos da Etapa 1.

Subsequentemente, procedeu-se às análises histopatológicas. Os animais foram randomizados em 5 grupos $(\mathrm{n}=4)$, sendo um grupo controle negativo e um grupo para cada um dos tempos 1, 7, 14 e 21 dias. Para averiguação do acometimento de metástases dos LNS e LNCL dos grupos do tratamento 2 foi utilizado o mesmo protocolo descrito acima. 


\section{Avaliação do potencial genotóxico por análise dos parâmetros de Fragmentação de DNA e Ciclo Celular (Tratamento 2)}

Células da medula óssea foram coletadas do fêmur dos animais de cada grupo e foram adicionadas em $1 \mathrm{~mL}$ de soro fetal bovino em tubo cônico. Em seguida, as células foram lavadas com PBS, fixadas em etanol $70 \%$ gelado e armazenadas a $-20^{\circ} \mathrm{C}$. Para a análise dos parâmetros de fragmentação de DNA e ciclo celular, as células foram centrifugadas $\left(500 g, 5\right.$ minutos, $\left.4^{\circ} \mathrm{C}\right)$ e incubadas com $300 \mu \mathrm{L}$ de tampão de lise $(0,1 \%$ citrato de sódio, $0,1 \%$ Triton $\mathrm{X}-100,20 \mu \mathrm{g} / \mathrm{mL}$ de RNAase) por 30 minutos à temperatura ambiente e protegidas da luz. As células foram analisadas em citômetro de fluxo (FACS Verse, Becton e Dickenson, EUA) e um total de 10.000 eventos foram computados por amostra.

\section{Avaliação Hematológica e Bioquímica (Tratamento 2)}

Os valores de referência, as possíveis alterações na morfologia, número de células, taxas dos componentes não celulares do sangue e o perfil bioquímico, foram objetos de estudo para avaliar alterações homeostáticas, resultantes da implantação das células tumorais e dos tratamentos (FELDMAN et al, 2000).

Para esse estudo foram considerados como valores de referência hematológico e bioquímico os dos analitos sanguíneos do grupo controle negativo, por contemplarem a real condição da população estudada. Esses valores de referência foram ainda comparados com valores de referência já estabelecidos na literatura (SOLBERG e CPETITCLERC, 1988; EVERDS, 2007; FERREIRA e ANDRIOLO, 2008; WEISS e WARDROP, 2010; BRANCO, 2011; ARAÚJO, 2012).

Dentro desse contexto foram realizados hemograma, dosagens bioquímicas de bilirrubina total, direta e indireta, aspartato aminotransferase (AST), alanina aminotransferase (ALT), gama glutamil transferase (GGT), fosfatase alcalina, creatinina, ureia, transferrina e ferro sérico.

Os procedimentos para a coleta de sangue (punção cardíaca) foram conduzidos respeitando-se o Guide for the Care and Use of Laboratory Animals (2008). Para a coleta do sangue, os animais foram anestesiados (conforme previamente descrito), via intraperitoneal, no quadrante lateral inferior direito. Após a anestesia geral, cuja profundidade foi avaliada por meio de ausência do reflexo podal, os animais foram posicionados em decúbito dorsal em bandeja forrada com etileno vinil acetato (EVA), 
de $100 \mathrm{~mm}$. Após assepsia do local com álcool 70\%, procedeu-se à punção cardíaca extracorpórea. Topograficamente o local da punção cardíaca era de 10 a $30^{0}$ acima da cavidade abdominal, lateralmente à cartilagem xifoide. $O$ volume total de sangue retirado foi de aproximadamente $800 \mu \mathrm{L}$. Utilizou-se para esse procedimento agulha $0,45 \times 13\left(26^{1 / 2}\right.$ ) de bico liso central (LuerSlip) e seringa de $2 \mathrm{~mL}$ jateada na parede com ácido etilenodiamino tetra-acético (EDTA). O sangue foi coletado em microtubos de 1,5 $\mathrm{mL}$ contendo $40 \mu \mathrm{L}$ de EDTA. O restante da amostra obtida foi colocado em tubos lavados com ativador de coagulação para análise bioquímica.

Após a coleta, as amostras foram imediatamente encaminhadas ao Núcleo de Apoio à Pesquisa do Laboratório Sabin ${ }^{\circledR}$ do Distrito Federal (DF), para análises e validações dos parâmetros hematológicos e bioquímicos.

\section{Sobrevida de Animais Tratados com Terapia Combinada}

\section{Taxa de sobrevida e histopatologia (Tratamento 2)}

Para confirmar a eficácia da cura, a sobrevida de animais submetidos ao Tratamento 2 foi avaliada até a ocorrência de óbito espontâneo. Para tanto, camundongos foram distribuídos randomicamente em 3 grupos $(\mathrm{n}=5)(\mathrm{sv}=$ sobrevida): controle negativo (G1sv), controle tumor (G2sv), e grupo tratado por duas semanas com a terapia combinada $(\mathrm{G} 3 \mathrm{sv}=\mathrm{TE}+\mathrm{MHT}+\mathrm{NPsel})$. Os animais foram monitorados diariamente e, a partir do registro da mortalidade diária, foram calculadas a taxa e a percentagem média de sobrevida. Necrópsia clínica e análise histopatológica para averiguação de acometimento de micrometástase linfonodal e metástases foram feitas logo após constatação da morte.

\section{Análise histopatológica}

A análise histopatológica desta etapa avaliou as secções dos seguintes fragmentos teciduais dos grupos controles e submetidos a tratamento: mama com tumor, mama contralateral, linfonodos subiliaco direitos e esquerdo, fígado, baço, rim, pulmão e cérebro. Nos grupos de sobrevida, além desses, também foram analisados os linfonodos jejunal, traqueobraquial, renal, mesentérico, mediastino cranial, gástrico, pancreaticojujenal e cólico (KAWASHIMA et al; 1964; VAN DEN BROECK et al, 2006). A eutanásia, protocolo para coleta dos fragmentos, fixação, coloração e plano de cortes para inclusão foram realizados conforme tabela 2 da Etapa 1. 


\section{RESULTADOS}

\section{Caracterização das Nanopartículas magnéticas recobertas com citrato}

(NPcit)

O fluído magnético utilizado neste experimento (NPcit) é baseado em NPM de maghemita $\left(\gamma-\mathrm{Fe}_{2} \mathrm{O}_{3}\right)$ recobertas com citrato. Suas características estão apresentadas na (Tabela 5). Exibiu coloração marrom e pH 7,0, com concentração de ferro de 16,8 $\mathrm{mg} / \mathrm{mL}$, conforme determinado por espectroscopia de absorção atômica; a estimativa da concentração de partículas foi $18 \times 10^{18}$ partículas $/ \mathrm{mL}$, apresentando diâmetro médio (DDRX) de $8 \mathrm{~nm}$. A medição da carga de superfície das NPM foi realizada através do potencial Zeta, exibindo $-49 \mathrm{mV}$, com tamanho hidrodinâmico de $66,34 \mathrm{~nm}$ e índice de polidispersão (PDI) de 0,236. Na Figura 20 é mostrada uma imagem de microscopia eletrônica de transmissão obtida de NPcit. A contagem de 348 nanopartículas magnéticas foi avaliada por curva log normal, tendo sido obtido o diâmetro $10 \mathrm{~nm}$ na frequência de distribuição de 30\% (Figura 23).

Tabela 4: Características do Npcit, FM baseado em NPM de maghemita $(\gamma-$ $\mathrm{Fe} 2 \mathrm{O} 3$ ) recobertas com citrato

\begin{tabular}{ll}
\hline Características do FM NPcit e de suas NPM & Valores \\
\hline Fórmula Molecular Maghemita & $\gamma-\mathrm{Fe}_{2} \mathrm{O}_{3}$ \\
Concentração de ferro determinada por absorção atômica & $16,8 \mathrm{mg}$ de ferro/mL \\
Concentração estimada de partículas & $18 \times 10^{18}$ partículas/mL \\
Diâmetro médio D DRX & $8 \mathrm{~nm}$ \\
Potencial zeta & $-49 \mathrm{mV}$ \\
Tamanho hidrodinâmico & $66,34 \mathrm{~nm}$ \\
PDI (índice de polidispersão) & 0,236 \\
pH & 7,0 \\
Cor & Marrom \\
\hline
\end{tabular}




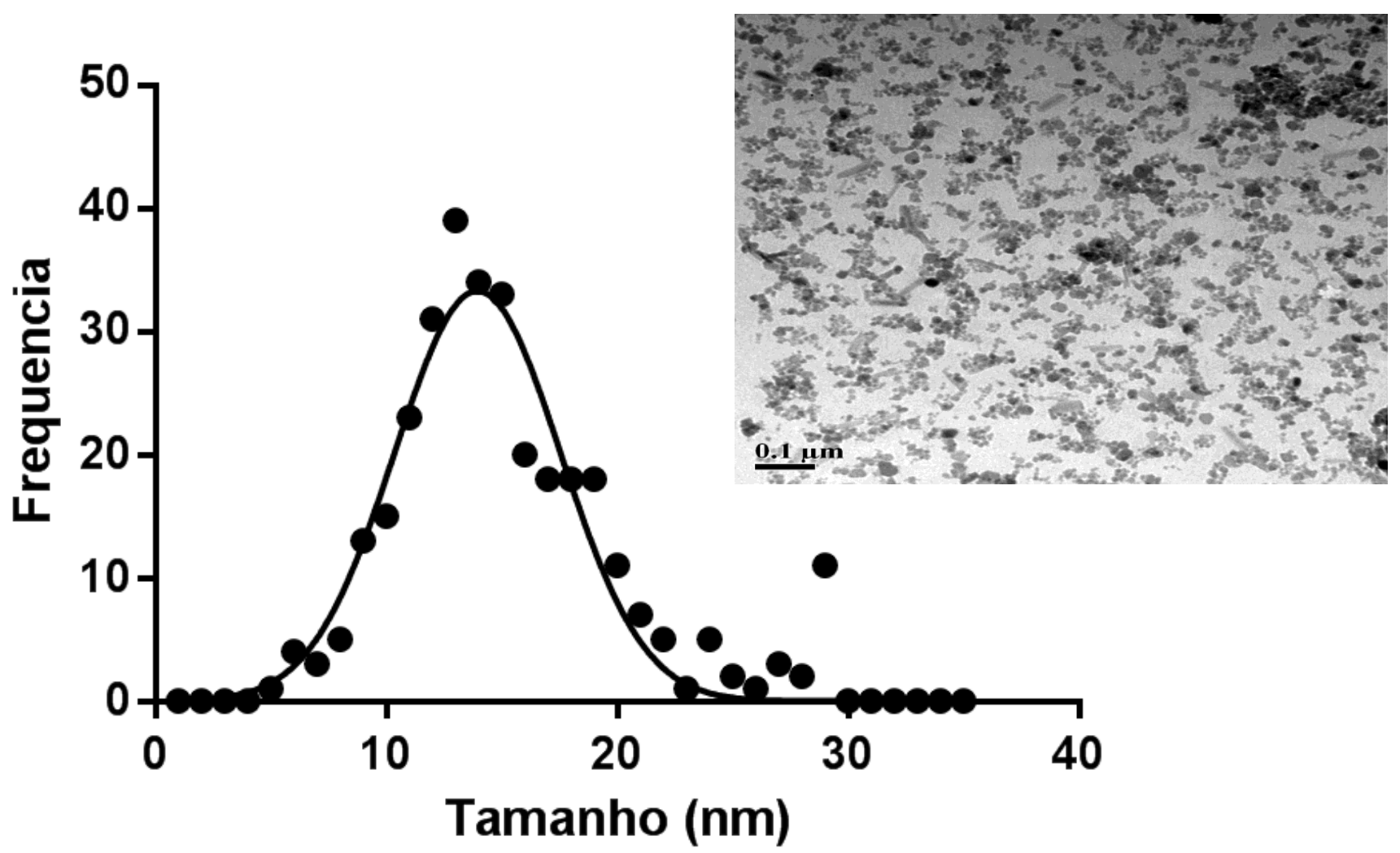

Figura 20: Imagem de NPcit obtida por MET. Diâmetro médio das NPM. Distribuição de tamanho (NPcit) obtida pela contagem de 348 NPM.

\section{Caracterização das Nanocápsulas de PLGA contendo Selol (NPsel)}

Na Figura 24 é mostrada uma imagem de microscopia eletrônica de varredura obtida de NPsel, observa-se que apesar dos aglomerados as nanopartículas na sua maioria apresentam um formato arredondado com superfície lisa. O tamanho médio, medido no Zeta Sizer, foi igual a $182,4 \pm 2,78 \mathrm{~nm}$ com um índice de polidispersão (PDI) de 0,158 $\pm 0,017$. A carga de superfície foi de - 0,605 $\pm 0,102$ com potencial hidrogeniônico $(\mathrm{pH})$ estabelecido em 7,0 (Tabela 6).

Tabela 5: Características das Nanocápsulas de PLGA contendo Selol

\begin{tabular}{ll}
\hline Nanocápsulas de PLGA contendo Selol & Valores \\
\hline Potencial zeta & $-0,605 \pm 0,102 \mathrm{mV}$ \\
Tamanho hidrodinâmico & $182,4 \pm 2,78 \mathrm{~nm}$ \\
PDI & $0,158 \pm 0,017$ \\
pH & 7,0 \\
\hline
\end{tabular}




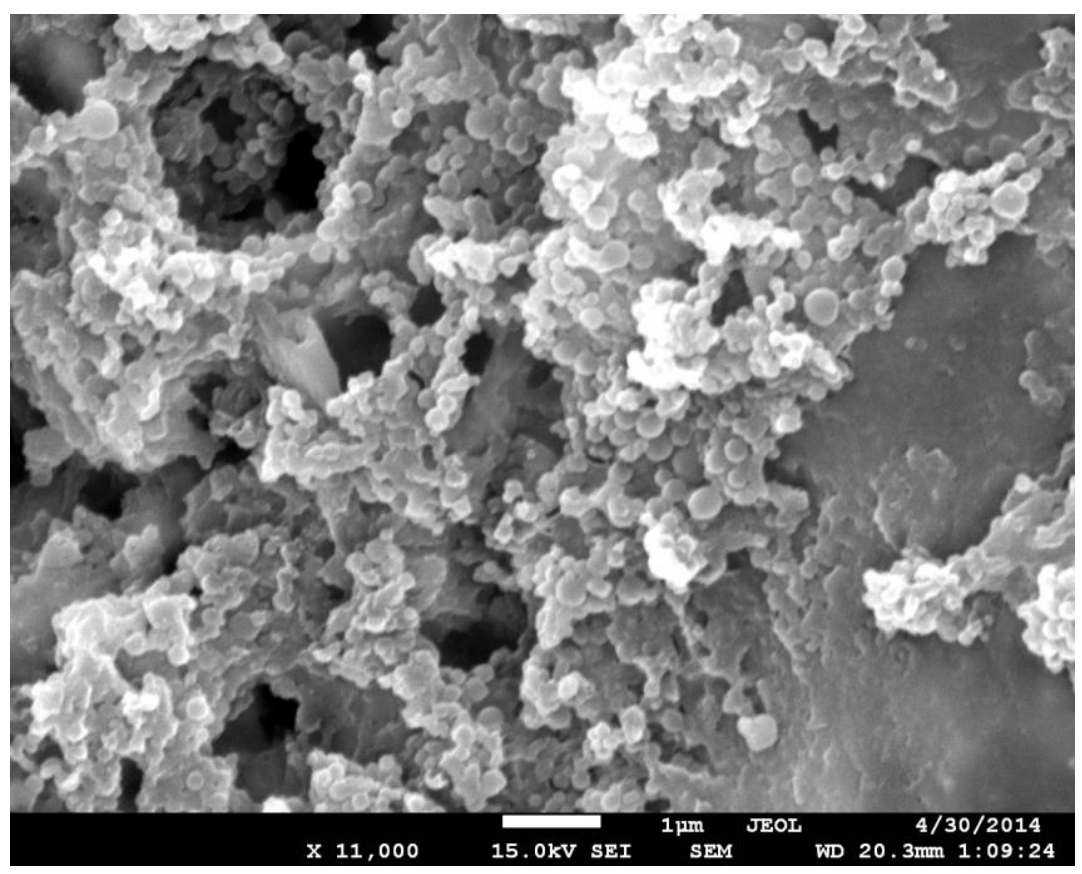

Figura 21: Micrografia eletrônica de varredura (MEV) de nanocápsulas contendo Selol.

\section{Termometria in vitro}

No ensaio de temperatura versus tempo da amostra NPcit exposta ao campo AC, foram obtidos os resultados descritos a seguir, os quais estão também mostrados na Figura 25. A medida da temperatura e termofotografias estão ilustradas na Figura 26, antes (Figura 26 A) e após a exposição ao campo magnético AC (Figura 26 B).

- $100 \mu \mathrm{L}$ da amostra NPcit alcançou $40^{\circ} \mathrm{C}$ em aproximadamente seis minutos, manteve-se estável até alcançar $50^{\circ} \mathrm{C}$, e progressivamente atingiu a temperatura final de $59^{\circ} \mathrm{C}$;

- $105 \mu \mathrm{L}$ da amostra NPcit alcançou a temperatura de $40^{\circ} \mathrm{C}$ após três minutos de exposição, manteve-se a $44^{\circ} \mathrm{C}$ por quinze minutos, seguido de queda para $40^{\circ} \mathrm{C}$, elevando-se para $44^{\circ} \mathrm{C}$ ate o final do ensaio;

- $110 \mu \mathrm{L}$ da amostra NPcit alcançou a temperatura de $42.60 \mathrm{C}$ próximo aos primeiros quatro minutos e permaneceu por uma hora em $43,7^{\circ} \mathrm{C}$.

- $1000 \mu \mathrm{L}$ da amostra NPcit alcançou a temperatura $50^{\circ} \mathrm{C}$ aos 12 minutos e elevando até próximo aos $60^{\circ} \mathrm{C}$. 


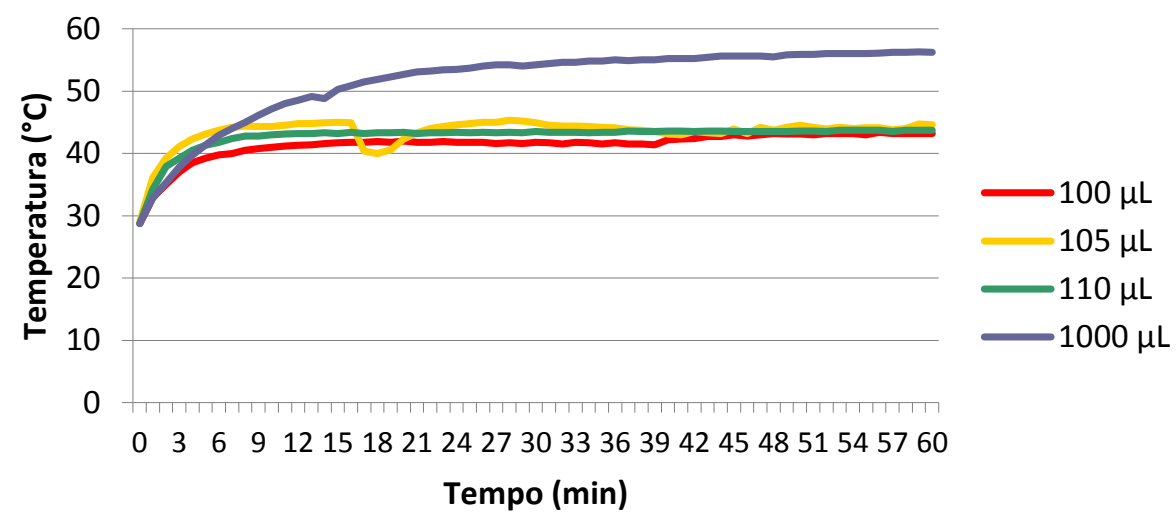

Figura 22: Curva de aquecimento da amostra nopartículas magnéticas recobertas com citrato em função do tempo e da quantidade de amostra usada.
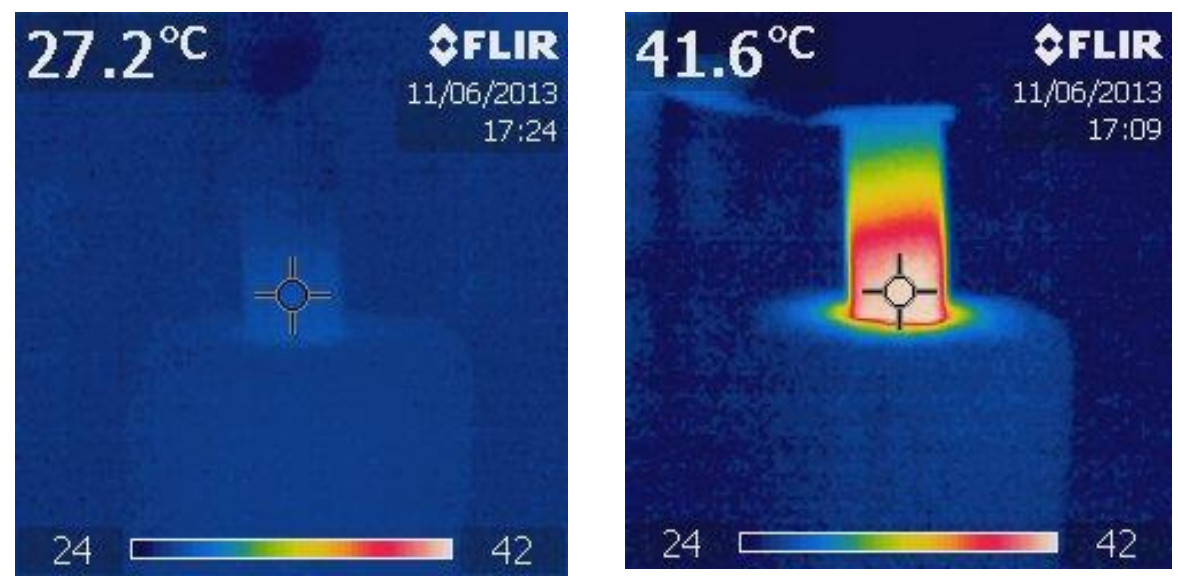

Figura 23: Termofotografias: $\mathrm{A}=$ tempo zero $27.2^{\circ} \mathrm{C}$; $\mathrm{B}=$ após a retirada do $\mathrm{AC} 41.6 .2$ ${ }^{\circ} \mathrm{C}$. A queda de $43,7^{0} \mathrm{C}$ (comentada no texto) para $41.7^{\circ} \mathrm{C}$ se deve ao tempo entre a retirada da amostra do equipamento de MHT e seu posicionamento para a fotografia.

\section{Análise microbiana do Selol}

Após 72 horas de cultivo para análise microbiana do Selol, não foi observado crescimento de microrganismos em qualquer um dos meios de cultura, nem qualquer sinal de alteração das características específicas dos meios, indicando que a amostra não apresentava contaminação por fungos ou bactérias (dados não mostrados). 


\section{Caracterização da presença de NPcit por MCT e distribuição por análise histopatológica (Tratamento2)}

Por meio das análises por microtomografia computadorizada (MCT) (Figura 27) foi identificada implantação do tumor na $5^{\mathrm{a}}$ glândula mamária (Figura 27B), medindo $8.517 \times 8.765 \mathrm{~mm}^{2}$, com invasão, deformação da cavidade abdominal e evidenciando nódulo sob a pele quando comparados com animais sem implantação tumoral (Figura 27A). De acordo com as imagens de MCT (Figura 27C) detectou-se a presença de NPcit peri e intratumoralmente, em imagem contrastada proporcionada pela própria presença das NPM. A técnica permitiu também obter imagens tridimensionais do tumor com a presença de NPM (Figura 27D) e no corte transversal (Figura 27E). No que concerne à distribuição por análise histopatológica, a presença de NPM foi observada intratumoralmente, utilizando coloração de Perls (Figura 27F) ou coloração com HE (Figura 27G).

\section{Tratamento 1, equipamento Magnetherm.}

Apesar de ser notória a diferença entre o tratamento 1a (1 semana) e o tratamento 1b (2 semanas), e do teste de análise de variância (ANOVA) ter detectado diferença entre as médias $(\mathrm{p}=0,001)$, nas comparações múltiplas, devido ao grande desvio padrão observado em cada um dos grupos experimentais, o teste de Tukey detectou diferença apenas para os controles NpCit $(\mathrm{p}=0,012)$. Este resultado em que há ausência de cura total (1a e 1b) nas duas tentativas nos estimulou a realizar o tratamento 2.

\section{Investigação do processo metastático e identificação dos LNS e LNCL}

As análises histopatológicas realizadas no grupo controle revelaram boa preservação do tecido linfonodal e ausência de alterações morfológicas, inclusive nos fragmentos dos rins, pulmões, fígados e baços (dados não apresentados).

Como mostrado na Tabela 7, no grupo investigado 7 dias após a inoculação, 80\% dos animais apresentaram acometimento do LNS, não tinham alterações no LNCL, no entanto, $10 \%$ dos animais apresentaram metaplasia óssea no baço e metástase pulmonar. No grupo 14 dias observou-se $90 \%$ de acometimento do LNS e de $20 \%$ no LNCL enquanto no grupo 21 dias a porcentagem de acometimento do LNS foi de $33 \% \mathrm{e}$ de $66,7 \%$ para LNCL. 

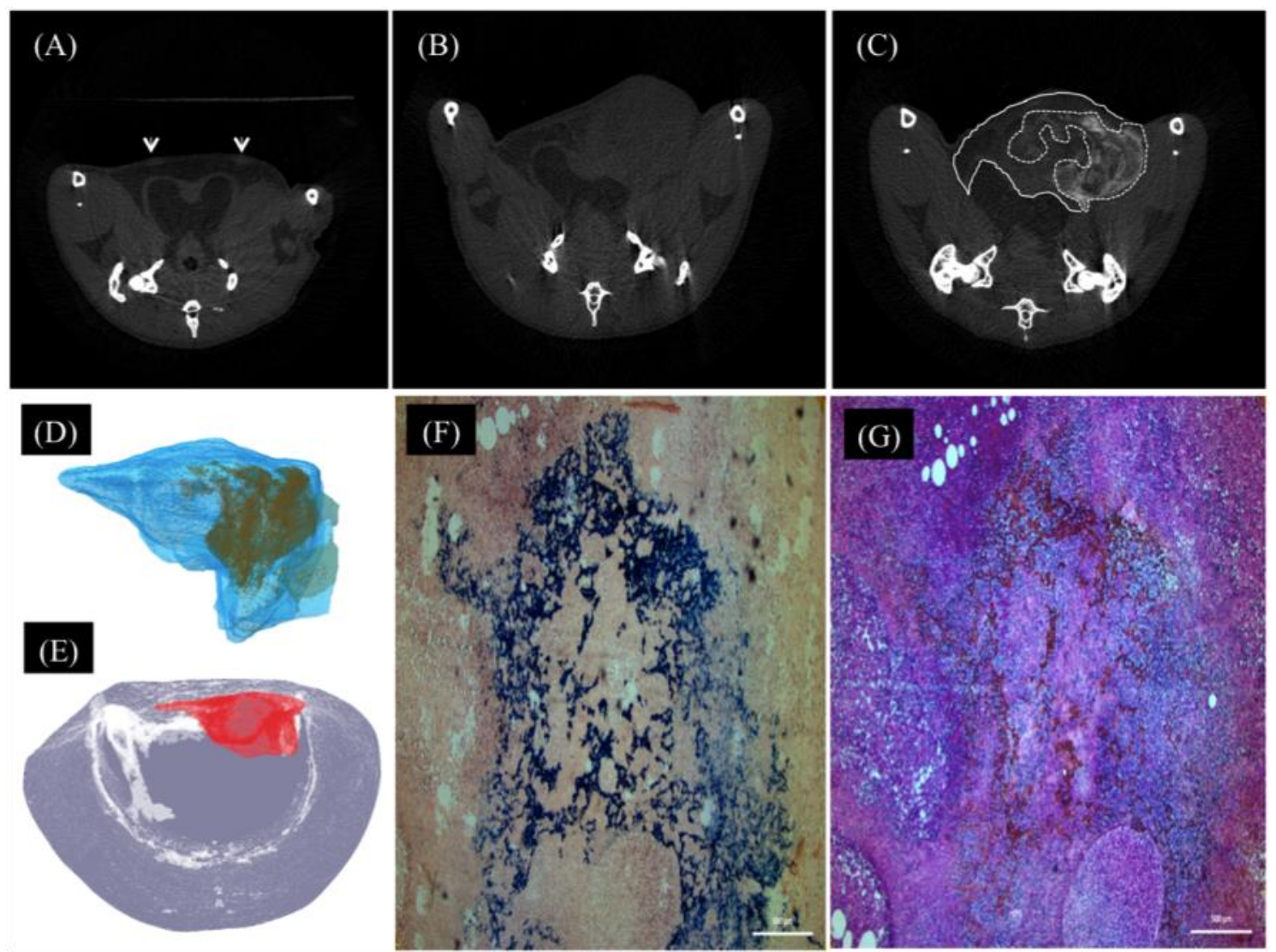

Figura 24: Distribuição de NPM por MCT e histologia do tumor: em A- imagem de MCT em um corte transversal de animal grupo controle negativo, cabeças de setas indicam papilas e glândulas mamárias, B- imagem nodular com densidade de partes moles, forma e margem irregulares acometendo região mamária inguinal medindo $8.517 \times 8.765 \mathrm{~mm}^{2}$. Ctumor com concentração de NPM peritumoral e intratumoral (demarcação pontilhada) e demarcação contínua massa tumoral. D-fotografia em 3D do tumor em Azul, marrom concentração de nanopartículas magnéticas peri e intratumoral E- fotografia em 3D animal do grupo controle negativo evidenciando em vermelho tumor, F e G cortes histológicos da $5^{\mathrm{a}}$ glândula mamaria com tumor, F- em Azul presença de NPM intratumoral em Azul, coloração de Perls. G- presença de NPM intratumoral com coloração de HE. 


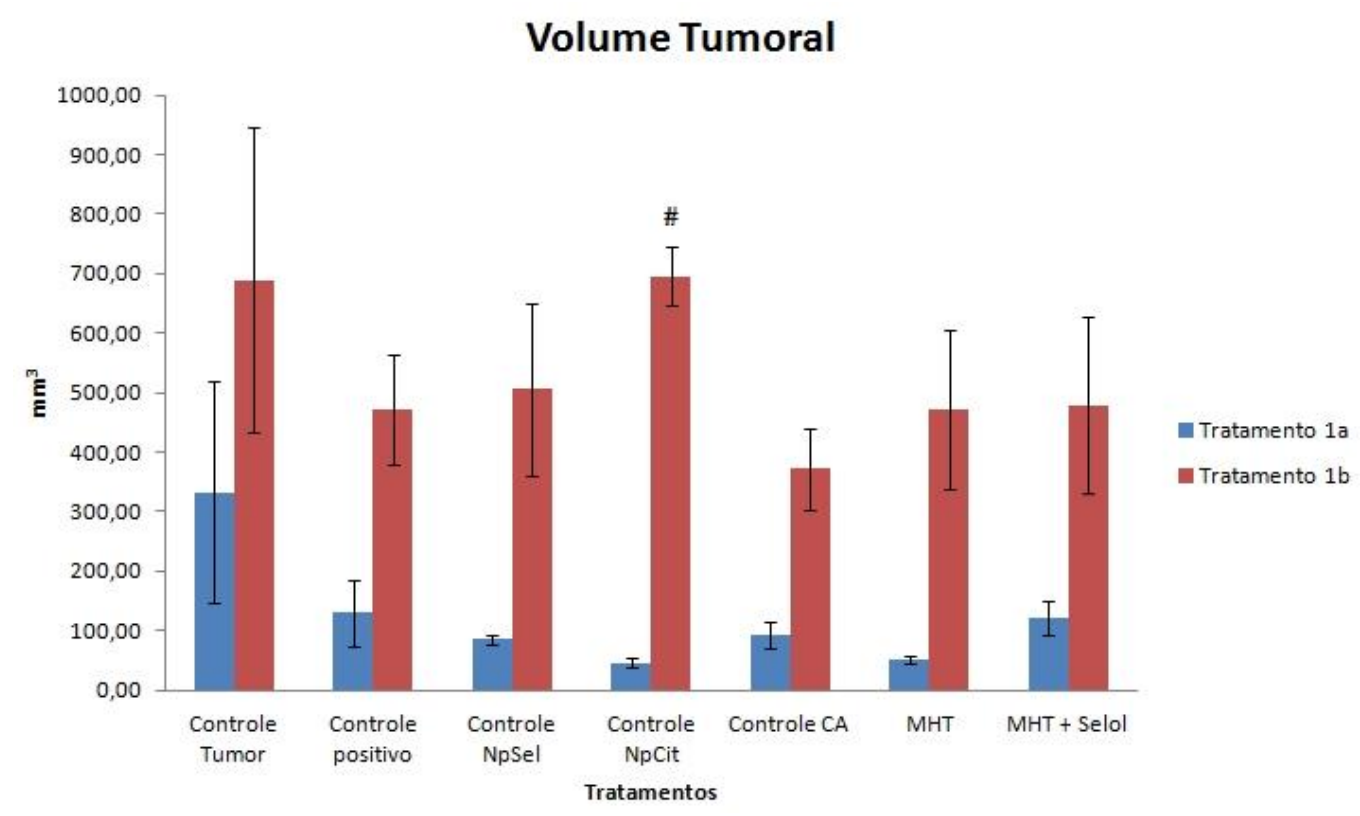

Figura 28: Volume tumoral $\left(\mathrm{em}^{3} \mathrm{~mm}^{3}\right)$ observado após tratamentos de uma semana (Tratamento 1a) e 2 semanas (Tratamento 1b).Os dados foram expressos como média e EPM (erro padrão da média). O símbolo \# indica diferença significativa detectada pelo teste de Tukey entre os tratamentos 1a e 1b.

Tabela 6: Acometimento por metástases do Linfonodo Sentinela (LNS) e do Linfonodo Contralateral (LNCL) dos animais acometidos por TE ortotópico.

\begin{tabular}{lcc}
\hline Grupos & LNS Positivo & LNCL Positivo \\
\hline 7 Dias & $80 \%$ & $0 \%$ \\
14 Dias & $90 \%$ & $20 \%$ \\
21 Dias & $33,30 \%$ & $0 \%$ \\
\hline
\end{tabular}

Avaliação do potencial genotóxico por análises dos parâmetros de fragmentação de DNA e ciclo celular (Tratamento 2)

Para o perfil do ciclo celular de células da medula óssea, foi realizado o teste ANOVA que revelou diferença entre os grupos apenas para G2/M (interfase/mitose) $(\mathrm{p}=0,25)$. Porém nenhuma diferença significativa foi detectada por meio do teste de Tukey nas comparações múltiplas entre os grupos (Figura 29). Já em relação ao parâmetro fragmentação do DNA (\%), a percentagem de DNA íntegro nos grupos 
tratados por MHT ou por NPsel foi significativamente maior do que aquela observada nos controles (Figura 30). Entretanto, o grupo correspondente à terapia combinada não apresenta diferença significativa com o grupo portando tumor, grupo este a apresentar a menor porcentagem de DNA íntegro.

\section{Hematologia e Bioquimica do Tratamento 2}

\section{Hematologia}

Entre os parâmetros hematológicos avaliados por ANOVA [hematócrito, leucócitos, linfócitos (\%), bastonetes (\% e ABS), segmentados (\% e ABS), monócitos

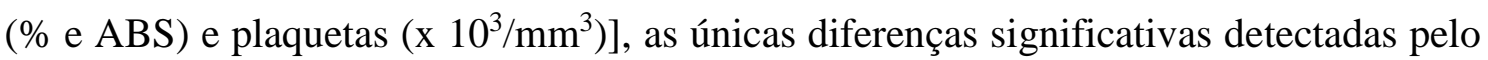
teste de Tukey nas comparações múltiplas foram observadas para monócitos (\%) e segmentados (ABS). Para monócitos, aumento significativo foi observado para o grupo MHT (G4) em relação ao controle negativo ( $\mathrm{G} 1 ; \mathrm{p}=0,034)$. Para segmentados, aumento significativo foi observado para o grupo G6 em relação aos controles negativo (G; $\mathrm{P}=0,025)$, positivo $(\mathrm{G} 2 ; \mathrm{p}=0,035)$ e controle tumor $(\mathrm{G} 3 ; \mathrm{p}=0,017)$ (Tabela 8).

Para os parâmetros hematológicos avaliados pelo teste de Kruskal-Wallis [hemácias, hemoglobina, hemoglobina corpuscular média (HCM), concentração de hemoglobina corpuscular média (CHCM), RVW, eosinófilos (\% e ABS), basófilos (\% e ABS), linfócitos (ABS) e VPM], várias diferenças significativas em relação ao controle negativo (G1) foram detectadas pelo teste de Mann-Whitney, particularmente no eritrograma e na contagem absoluta de linfócitos (linfócitos ABS) (Tabela 8). No eritrograma, a implantação do tumor (G3) provocou reduções significativas nos valores de hemácias $(\mathrm{p}=0,021)$, hemoglobina $(\mathrm{p}=0,008), \operatorname{HCM}(\mathrm{p}=0,030)$, e CHCM $(\mathrm{p}=0,042)$ em comparação ao controle negativo, onde os valores de CHCM ficaram abaixo dos valores de referência para camundongos (30-38 g/dL) (EVERDS, 2007). O tratamento MHT (G4) reduziu ainda mais os valores de hemoglobina ( $p=0,004), \operatorname{HCM}(p=0,003)$ e CHCM ( $p=0,031)$, para níveis inferiores aos valores de referência (hemoglobina= 10-17 g/dL; HCM=15-18 pg; CHCM=30-38 g/dL) (EVERDS, 2007). O tratamento com NPsel (G5) fez com que os valores de HCM e CHCM voltassem aos níveis normais, apesar de ainda manter diferença significativa em relação ao controle negativo para os valores de hemoglobina $(\mathrm{p}=0,029)$, porém, dentro dos valores de referência. Já o tratamento combinado com MHT+ NPsel (G6), apesar de ter normalizado os valores de CHCM, 
ainda manteve redução significativa em relação ao controle negativo para os valores de hemoglobina ( $\mathrm{p}=0,022)$ e $\mathrm{HCM}(\mathrm{P}=0,022)$, porém dentro dos valores de referência para camundongos (EVERDS, 2007). Em relação ao leucograma, enquanto o controle positivo $(\mathrm{G} 2 ; \mathrm{p}=0,025)$ e o tumor $(\mathrm{G} 3 ; \mathrm{P}=0,007)$ promoveram reduções significativas na contagem absoluta de linfócitos (linfócitos ABS) em comparação ao controle negativo, o tratamento combinado com MHT+ NPsel (G6) aumentou significativamente os valores absolutos de segmentados (Segmentados $\mathrm{ABS} ; \mathrm{P}=0,025)$, porém todos eles sem diferenças significativas em relação à percentagem (\%) dessas células. Nenhuma diferença em relação ao controle negativo foi observada no plaquetograma.

\section{Bioquímica}

O tratamento com paclitaxel (controle positivo; G2) e a instalação do tumor (G3) provocaram diversas alterações nos parâmetros bioquímicos, quando comparados ao controle negativo (G1) (Tabela 8). Das alterações provocadas pela implantação do tumor (G3), cabe ressaltar o aumento significativo de TGO (transaminase glutâmica oxalacética) (AST; $\mathrm{P}=0,015)$ e redução significativa de ferro sérico $(\mathrm{P}=0,000)$, ambos normalizados apenas com o tratamento conjugado MHT+NPsel (Tabela 9). 
G1
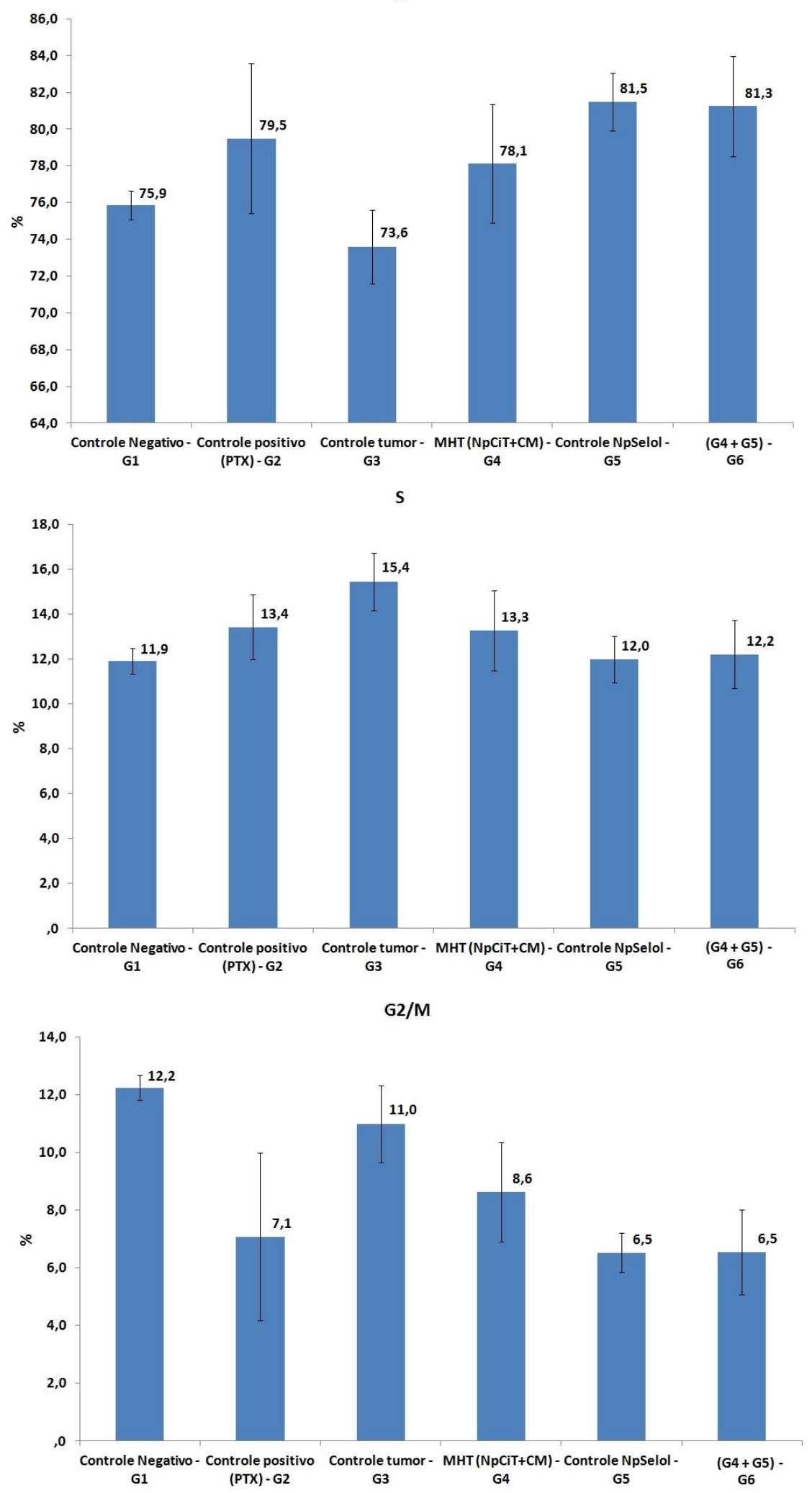

Figura 29: Perfil do ciclo celular de células de medula óssea após Tratamento 2 dos animais. Os dados foram expressos como média e EPM (erro padrão da média). 


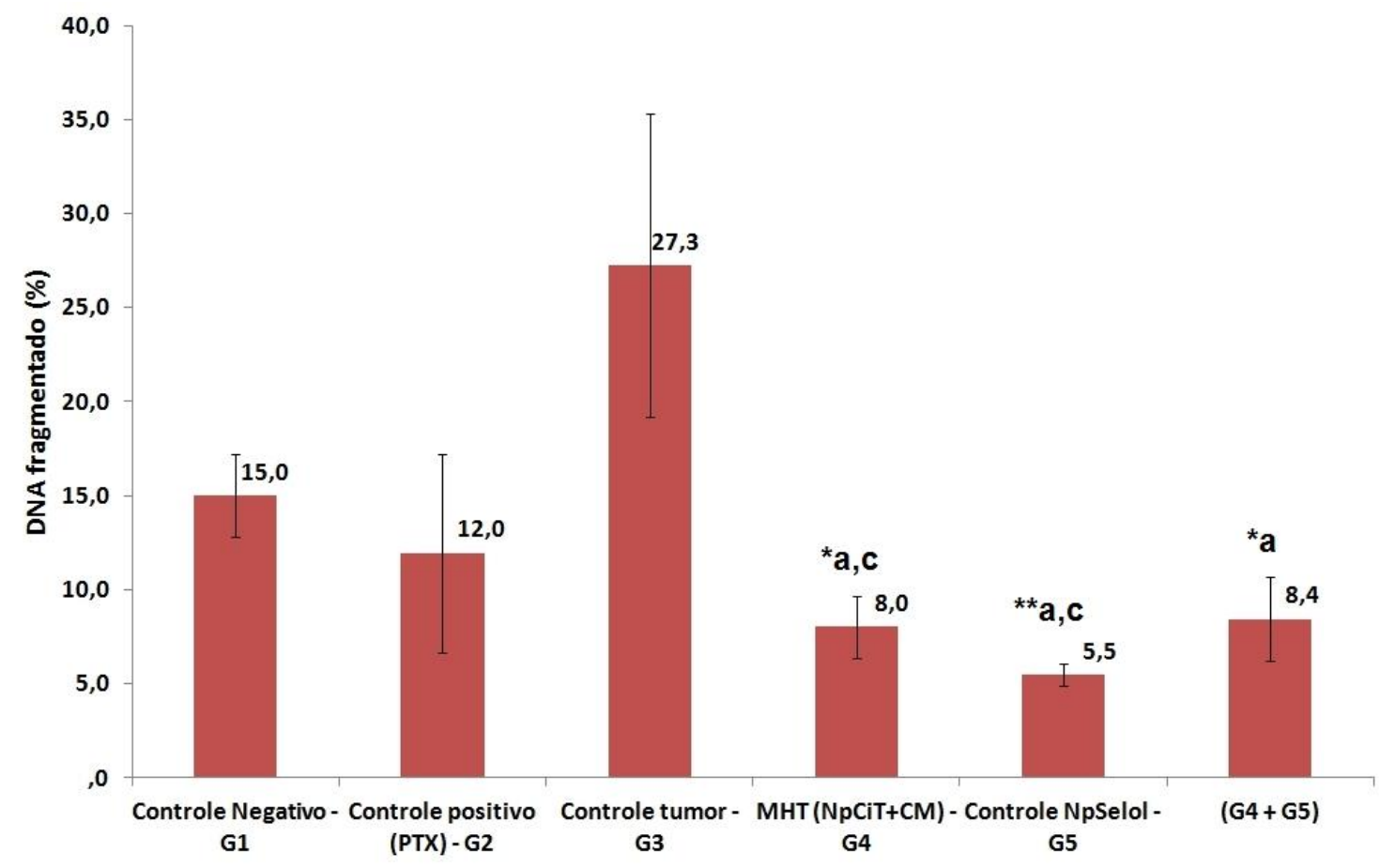

Figura 30: Avaliação da genotoxicidade por análise de fragmentação de DNA de células de medula óssea. Os dados foram expressos como média e EPM (erro padrão da média). As letras minúsculas indicam diferenças significativas nas comparações 2-a-2 detectadas por Mann-Whitney, sendo $\mathrm{a}=$ significativo comparada a G1; $\mathrm{c}=$ significativo comparado G3. Os asteriscos indicam diferenças significativas ao nível de $* \mathrm{p}<0,05$ e $* * \mathrm{p}<0,01$. 
Tabela 7: Hematologia dos animais do grupo Tratamento 2 .

\begin{tabular}{|c|c|c|c|c|c|c|c|}
\hline Tratamento & Controle Negativo - G1 & Controle positivo (PTX) - G2 & Controle tumor - G3 & MHT (NPcit+CM) - G4 & Controle NPsel - G5 & $\begin{array}{l}\text { (G4 + G5) } \\
\text { G6 }\end{array}$ & p-valor \\
\hline \multicolumn{8}{|l|}{ Eritograma } \\
\hline Hemácias milhões $/ \mathrm{mm}^{3}$ & $9,19 \pm 0,18$ & $8,99 \pm 0,27$ & $8,20 \pm 0,36^{* a}$ & $7,54 \pm 1,02$ & $7,95 \pm 0,49$ & $7,74 \pm 1,03$ & 0,122 \\
\hline Hemoglobina $\mathrm{g} / \mathrm{dL}$ & $14,46 \pm 0,38$ & $13,43 \pm 0,48$ & $12,11 \pm 0,6^{* *_{a}}$ & $8,72 \pm 2,32^{* a}$ & $11,33 \pm 1,18^{* a}$ & $11,03 \pm 1,74^{* a}$ & 0,007 \\
\hline Hematocrito (\%) & $47,56 \pm 1,80$ & $43,53 \pm 1,86$ & $43,07 \pm 1,64$ & $36,82 \pm 4,7$ & $38,8 \pm 2,67$ & $36,23 \pm 4,77$ & 0,036 \\
\hline $\operatorname{VCM}(\mathrm{fl})$ & $51,60 \pm 1,28$ & $48,40 \pm 0,79$ & $52,76 \pm 1,51$ & $49,28 \pm 1,65$ & $48,77 \pm 1,29$ & $46,80 \pm 0,86$ & 0,106 \\
\hline $\mathrm{CHCM} \mathrm{g} / \mathrm{dL}$ & $30,57 \pm 0,58$ & $30,87 \pm 0,22$ & $28,11 \pm 0,88^{*_{a}}$ & $23,12 \pm 5,03^{* a}$ & $29,17 \pm 1,83$ & $30,10 \pm 1,04$ & 0,129 \\
\hline RDW & $17,16 \pm 0,43$ & $17,80 \pm 0,59$ & $18,46 \pm 1,08$ & $17,32 \pm 0,74$ & $17,57 \pm 1,25$ & $17,90 \pm 0,53$ & 0,990 \\
\hline \multicolumn{8}{|l|}{ Leucograma } \\
\hline Leucócitos & $3990,00 \pm 591,5$ & $2166,67 \pm 470,22$ & $2500,00 \pm 320,71$ & $4360,00 \pm 1569,27$ & $3966,67 \pm 202,76$ & $6100,00 \pm 1234,91$ & 0,093 \\
\hline Linfócitos (\%) & $67,00 \pm 12,54$ & $84,00 \pm 3,21$ & $74,43 \pm 4,73$ & $69,40 \pm 5,63$ & $65,67 \pm 15,10$ & $40,50 \pm 15,07$ & 0,399 \\
\hline Segmentados (\%) & $32,10 \pm 12,46$ & $9,67 \pm 4,63$ & $21,00 \pm 4,01$ & $19,00 \pm 7,73$ & $23,33 \pm 13,91$ & $50,75 \pm 18,28$ & 0,442 \\
\hline Eosinofilos (\%) & $0,10 \pm 0,10$ & $0,67 \pm 0,67$ & $0,14 \pm 0,14$ & $0,60 \pm 0,40$ & $0,00 \pm 0,00$ & $0,25 \pm 0,25$ & 0,493 \\
\hline Basofilos (\%) & $0,00 \pm 0,00$ & $0,00 \pm 0,00$ & $0,00 \pm 0,00$ & $0,20 \pm 0,20$ & $0,00 \pm 0,00$ & $0,00 \pm 0,00$ & 0,493 \\
\hline Monócitos (\%) & $0,80 \pm 0,13$ & $5,67 \pm 2,03$ & $4,43 \pm 0,95$ & $10,60 \pm 3,79^{* a}$ & $9,67 \pm 4,81$ & $8,50 \pm 4,99$ & 0,031 \\
\hline Linfócitos ABS & $4528,20 \pm 589,63$ & $1821,00 \pm 407,04^{* a}$ & $1848,14 \pm 262,16^{* *_{a}}$ & $2797,40 \pm 794,30$ & $2544,67 \pm 475,95$ & $2062,75 \pm 719,93$ & 0,057 \\
\hline Segmentados ABS & $481,20 \pm 91,96$ & $211,67 \pm 90,77$ & $544,57 \pm 149,84$ & $1229,60 \pm 786,06$ & $975,00 \pm 612,55$ & $3655,25 \pm 1400,29^{* a, b, c}$ & 0,019 \\
\hline Bastonetes ABS & $0,00 \pm 0,00$ & $0,00 \pm 0,00$ & $0,00 \pm 0,00$ & $6,40 \pm 6,40$ & $57,33 \pm 57,33$ & $0,00 \pm 0,00$ & 0,353 \\
\hline Eosinofilos ABS & $0,00 \pm 0,00$ & $12,00 \pm 12,00$ & $2,86 \pm 2,86$ & $44,20 \pm 41,03$ & $0,00 \pm 0,00$ & $21,00 \pm 21,00$ & 0,565 \\
\hline Basofilos ABS & $0,00 \pm 0,00$ & $0,00 \pm 0,00$ & $0,00 \pm 0,00$ & $2,6 \pm 2,6$ & $0,00 \pm 0,00$ & $0,00 \pm 0,00$ & 0,493 \\
\hline Monocitos ABS & $50,60 \pm 6,19$ & $122,00 \pm 44,68$ & $104,43 \pm 26,02$ & $279,80 \pm 35,11$ & $389,67 \pm 193,37$ & $361,00 \pm 126,68$ & 0,013 \\
\hline \multicolumn{8}{|l|}{ Plaquetograma } \\
\hline Plaquetas $\times 10^{3} / \mathrm{mm}^{3}$ & $553,09 \pm 68,01$ & $594,67 \pm 84,89$ & $500,14 \pm 74,78$ & $371,00 \pm 103,08$ & $516,67 \pm 75,40$ & $715,50 \pm 152,95$ & 0,342 \\
\hline VPM fl & $7,18 \pm 0,13$ & $6,93 \pm 0,27$ & $7,21 \pm 0,09$ & $7,35 \pm 0,24$ & $7,10 \pm 0,50$ & $7,60 \pm 0,06^{* \mathrm{c}}$ & 0,375 \\
\hline
\end{tabular}

Os dados correspondem à média e ao erro padrão da média (EPM). VCM= Volume Corpuscular Médio; HCM= Hemoglobina Corpuscular Média; CHCM= Concentração Hemoglobínica Corpuscular Média; RDW= amplitude de distribuição do tamanho dos eritrócitos (do inglês, Red cell distribution width; $\mathrm{ABS}=$ número absoluto; $\mathrm{g} / \mathrm{dL}=$ gramas por decilitros; fl = fentolitros; pg = picograma. Os p-valores de hematócrito, VCM, linfócitos (\%), segmentados (\% e ABS), (1) 
Tabela 8: Bioquímica dos animais do grupo Tratamento 2

\begin{tabular}{|c|c|c|c|c|c|c|c|}
\hline & $\begin{array}{l}\text { Controle } \\
\text { Negativo - G1 }\end{array}$ & $\begin{array}{l}\text { Controle positivo } \\
\text { (PTX) - G2 }\end{array}$ & $\begin{array}{l}\text { Controle } \\
\text { tumor - G3 }\end{array}$ & $\begin{array}{l}\text { MHT } \\
\text { (NPcit+CM) - G4 }\end{array}$ & NPsel - G5 & $\begin{array}{l}\text { (G4 + G5) } \\
\text { G6 }\end{array}$ & $\begin{array}{l}\mathrm{p}- \\
\text { valor }\end{array}$ \\
\hline \multicolumn{8}{|l|}{ Bioquímica } \\
\hline Bilirrubina direta $(\mathrm{mg} / \mathrm{dL})$ & $0,04 \pm 0,01$ & $0,01 \pm 0,00^{* a}$ & $0,02 \pm 0,01^{* a}$ & $0,01 \pm 0,00^{* a}$ & $0,01 \pm 0,00^{* a}$ & $0,03 \pm 0,01$ & 0,030 \\
\hline Bilirrubina indireta $(\mathrm{mg} / \mathrm{dL})$ & $0,03 \pm 0,01$ & $0,01 \pm 0,00^{* a}$ & $0,02 \pm 0,00$ & $0,01 \pm 0,00^{* a}$ & $0,03 \pm 0,01$ & $0,03 \pm 0,01$ & 0,160 \\
\hline $\mathrm{TGO}(\mathrm{AST})-\mu / \mathrm{L}$ & $102,18 \pm 9,65$ & $511,67 \pm 77,68^{* *_{a}}$ & $327,08 \pm 33,63^{* a}$ & $483,60 \pm 139,20^{* *_{a}}$ & $448,80 \pm 114,50^{* * a}$ & $224,67 \pm 20,36$ & 0,000 \\
\hline Gama glutamil transferase $(\mu / \mathrm{L})$ & $4,10 \pm 1,19$ & $0,67 \pm 0,33^{* a}$ & $2,17 \pm 0,27^{* \mathrm{~b}}$ & $2,00 \pm 0,32^{* b}$ & $1,60 \pm 0,24$ & $1,83 \pm 0,31$ & 0,086 \\
\hline Fosfatase alcalina $(\mu / \mathrm{L})$ & $74,00 \pm 8,56$ & $58,33 \pm 12,35$ & $49,75 \pm 7,74$ & $29,00 \pm 3,27^{* * a}$ & $40,40 \pm 5,48^{* a}$ & $36,67 \pm 3,58^{* * a}$ & 0,006 \\
\hline Creatinina $(\mathrm{mg} / \mathrm{dL})$ & $0,09 \pm 0,01$ & $0,10 \pm 0,00$ & $0,10 \pm 0,00$ & $0,10 \pm 0,00$ & $0,10 \pm 0,00$ & $0,10 \pm 0,03$ & 0,594 \\
\hline Ureia $(\mathrm{mg} / \mathrm{dL})$ & $55,36 \pm 4,26$ & $34,00 \pm 4,58^{* a}$ & $46,08 \pm 3,41$ & $46,60 \pm 11,03$ & $39,60 \pm 2,27^{* a}$ & $36,50 \pm 2,85^{* * a}$ & 0,022 \\
\hline Ferro sérico $(\mu \mathrm{g} / \mathrm{dL})$ & $194,82 \pm 14,23$ & $108,00 \pm 18,01^{*_{a}}$ & $115,67 \pm 13,06^{* *_{a}}$ & $134,20 \pm 7,23$ & $118,60 \pm 12,18^{* a}$ & $145,50 \pm 12,73$ & 0,000 \\
\hline
\end{tabular}

Os dados correspondem à média e ao erro padrão da média (EPM). Os p-valores de TGO, TGP e ferro sérico foram gerados por ANOVA, enquanto os demais pvalores foram gerados pelo teste de Kruskal-Wallis. As letras minúsculas indicam diferenças significativas nas comparações 2-a-2 detectadas pelo teste de Tukey ou MannWhitney, sendo a= significativo comparado a G1; b= significativo comparado a G2; c= significativo comparado G3. Os asteriscos indicam diferenças significativas ao nível de $* p<0,05$ e $* * p<0,01$. 


\section{Variação ponderal dos animais tumor e peso do baço (tratamento2)}

As alterações ponderais ocorridas durante o tratamento 2, correlacionando os animais, tumores, baços, e as injeções de PTX, bem com nas inoculações de TE antes e depois dos tratamentos, foram analisadas por ANOVA, seguido pelo pós-teste MannWhitney. Entre as alterações ocorridas antes da eutanásia (durante o tratamento) destacam-se o aumento de peso nos animais dos grupos G3 ( $\mathrm{P}=0,003), \mathrm{G} 4(\mathrm{P}=0,4), \mathrm{G} 5$ $(\mathrm{P}=0,014)$ e $\mathrm{G6}(\mathrm{P}=0,04)$, (controle tumor e os grupos tratados), quando comparados com G2, o controle Paclitaxel. Do mesmo modo, evidenciou-se redução do peso de G4, MHT, $(\mathrm{P}=0,011)$ quando comparados com G3, controle tumor (Tabela 10). O aumento do peso do baço pode ser observado nos grupos $\mathrm{G} 3(\mathrm{P}=0,16)$, controle tumor, e $\mathrm{G} 4$ $(\mathrm{P}=0,10), \mathrm{G} 5(\mathrm{P}=0,025)$ e $\mathrm{G} 6(\mathrm{P}=0,20)$, os grupos tratados, quando comparados ao $\mathrm{G} 1$, controle negativo. Quanto ao volume tumoral, é notória a redução significativa desta característica após o tratamento com as terapias combinadas, grupo G6 ( $\mathrm{P}=0,022)$, quando comparadas a G3 e a G5, controle tumor e NPsel, respectivamente (Tabela 11). 
Tabela 9: Peso dos animais e peso do baço dos animais Tratamento 2

\begin{tabular}{|c|c|c|c|c|c|c|c|}
\hline Tratamento & $\begin{array}{l}\text { Controle } \\
\text { Negativo - G1 }\end{array}$ & $\begin{array}{l}\text { Controle positivo } \\
\text { (PTX) - G2 }\end{array}$ & $\begin{array}{l}\text { Controle tumor - } \\
\text { G3 }\end{array}$ & $\begin{array}{l}\text { MHT (NPcit+CM) } \\
\text { - G4 }\end{array}$ & NPsel - G5 & $\begin{array}{l}\text { (G4 + G5) } \\
\text { G6 }\end{array}$ & p-valor \\
\hline $\begin{array}{l}\text { Peso animal } \\
\text { antes } \quad(\mathrm{g}) \quad \mathrm{da} \\
\text { eutanásia }\end{array}$ & $27,13 \pm 2,23$ & $32,68 \pm 0,43$ & $38,28 \pm 1,86^{* * a}$ & $37,46 \pm 1,52^{* * a, b}$ & $37,67 \pm 2,41^{* a}$ & $37,85 \pm 1,63^{* * a}$ & 0,004 \\
\hline $\begin{array}{lr}\text { Peso animal } \\
\text { depois } \\
\text { depois }\end{array}$ & $38,47 \pm 27,56$ & $34,40 \pm 0,96$ & $38,74 \pm 1,83$ & $35,12 \pm 1,50$ & $36,72 \pm 1,82$ & $33,60 \pm 0,96$ & 0,093 \\
\hline Peso Baço & $0,24 \pm 0,03$ & $0,32 \pm 0,04$ & $0,35 \pm 0,02^{* a}$ & $0,57 \pm 0,11^{* * a}$ & $0,50 \pm 0,11^{* a}$ & $0,48 \pm 0,10^{* a}$ & 0,018 \\
\hline
\end{tabular}

Os dados correspondem à média e ao erro padrão da média (EPM). Os p-valores foram gerados pelo teste de Kruskal-Wallis. As letras minúsculas indicam diferenças significativas nas comparações 2-a-2 detectadas Mann-Whitney, sendo a= significativo comparado a G1; b= significativo comparado a G2; c= significativo comparado G3. Os asteriscos indicam diferenças significativas ao nível de *p<0,05 e **p<0,01. 
Tabela 10: Volume e peso do tumor - Tratamento 2

\begin{tabular}{|c|c|c|c|c|c|c|}
\hline Tratamento & Controle positivo (PTX) - G2 & Controle tumor - G3 & MHT (NPcit+CM) - G4 & Controle NPsel - G5 & (G4 + G5) - G6 & p-valor \\
\hline Volume tumor (mm3) & $724,74 \pm 151,20$ & $856,13 \pm 176,54$ & $723,66 \pm 242,83$ & $803,09 \pm 162,15$ & $296,14 \pm 106,14^{* b, d}$ & 0,147 \\
\hline Peso tumor (mg) & $1027,30 \pm 315,24$ & $1065,51 \pm 182,33$ & $885,90 \pm 326,42$ & $920,90 \pm 162,38$ & $575,48 \pm 120,54$ & 0,601 \\
\hline
\end{tabular}

Os dados correspondem à média e ao erro padrão da média (EPM). Os p-valores foram gerados pelo teste de Kruskal-Wallis. As letras minúsculas indicam diferenças significativas nas comparações 2-a-2 detectadas Mann-Whitney, sendo b= significativo comparado a G3; d= significativo comparado G5. Os asteriscos indicam diferenças significativas ao nível de $* \mathrm{p}<0,05$. 


\section{Status Linfonodal dos Grupos do Tratamento 2}

\section{Acometimento de micrometástases nos LNS e LNCL tratamento 2}

$\mathrm{Na}$ análise histopatológica de todos os fragmentos do grupo controle negativo, não foram visualizadas alterações morfológicas nem acometimento de metástases (tabela 12).

Aos 7 dias de tratamento, não foi constatado acometimento por micrometástase nos LNS e LNCL em nenhum dos grupos portando tumores, quer controle positivo (G2), controle tumor (G3, não foi possível excisar o LNS), ou grupos tratados G4, G5 e G6.

Lembrando que os sub-grupos (a) foram tratados por 1 semana e tiveram a coleta dos tecidos (fragmentos) feita 1 semana depois (2 semanas após inoculação do tumor) e que nos sub-grupos (b), o tratamento ocorreu por 2 semanas (coleta 3 semanas após inoculação do tumor), observou-se que em todos os sub-grupos (a) não houve acometimento linfonodal. Por outro lado, todos os sub-grupos (b) apresentaram algum tipo de acometimento (grupo controle tumor G1b com $20 \%$ no LNS e $10 \%$ no LNCL grupo MHT G2b com 67\% tanto no LNS, quanto no LNCL; grupo tratado com NPsel G3b com $60 \%$ no LNS e $20 \%$ no LNCL, grupo tratado com PTX com 50\% no LNS), exceto o grupo tratado com a terapia combinada MHT + NPsel + NPcit, em que $100 \%$ dos animais ficaram livres de acometimento metastático na rede linfonodal e órgãos. 
Tabela 11: Acometimento de metástase no LNS, LNSCL e órgãos

\begin{tabular}{|c|c|c|c|c|}
\hline Grupos & $\begin{array}{l}* \text { LNS } \\
\text { positivo }\end{array}$ & $\begin{array}{l}* * \text { LNSCL } \\
\text { positivo }\end{array}$ & Metástase & $\begin{array}{l}\text { Outros } \\
\text { achados }\end{array}$ \\
\hline Controle negativo & - & - & - & - \\
\hline *\#G1a (cont. Tumor) & - & - & - & - \\
\hline \#\#G1 b (cont. Tumor) & $20 \%$ & $10 \%$ & - & - \\
\hline \#G2 a (NPcit+CMag) & - & - & - & - \\
\hline \#G2 b (NPcit+CMag) & $67 \%$ & $67 \%$ & - & - \\
\hline $\begin{array}{l}\text { \#G3 a (quimioterapia } \\
\text { NPsel) }\end{array}$ & - & - & - & - \\
\hline $\begin{array}{l}\text { \#G3 b (quimioterapia } \\
\text { NPsel) }\end{array}$ & $60 \%$ & $20 \%$ & - & - \\
\hline $\begin{array}{l}\text { \#G4a } \\
\text { (CMag+NPcit+NPsel) }\end{array}$ & & - & - & - \\
\hline $\begin{array}{l}\text { \#G4b } \\
(\mathrm{CMag}+\mathrm{NPcit}+\mathrm{NPsel})\end{array}$ & - & - & - & - \\
\hline \#G5 a (cont. PTX) & - & - & - & - \\
\hline \#G5 b (cont. PTX) & $50 \%$ & - & - & - \\
\hline
\end{tabular}

LNS $=$ Linfonodo subiliaco direito, ${ }^{*}$ LNSCL $=$ Linfonodo subiliaco esquerdo. Eutanásia ou tratamento - \# início do tratamento 24 após inoculação - \#\# eutanásia 7 dias após fim do tratamento

\section{Análise de sobrevida (Tratamento2)}

Após a constatação de que a magnetohipertermia e a quimioterapia combinadas levavam a uma significativa redução do volume tumoral e não levavam a acometimento metastático linfonodal ou de órgãos, foi feita a análise da sobrevida desse grupo de animais (Figura 31). Divididos em 3 grupos $(\mathrm{N}=5)$, constatou-se que os óbitos espontâneos tiveram início no grupo controle tumor $(\mathrm{G} 2)$ : o primeiro animal foi a óbito no $42^{0}$ dia após a inoculação ortotópica, dois animais no $43^{0}$ dia, e os dois últimos animais no $44^{0}$ dia após o inicio da análise de sobrevida. A análise histopatológica dos fragmentos teciduais, dos três animais desse grupo com óbito aos 43 e 44 dias após a 
inoculação mostrou severos acometimentos em toda rede linfonodal, com micrometástase nos linfonodos jejunal, traqueobraquial, renal, mesentérico, mediastino cranial, gástrico, pancreaticojujenal e cólico, assim como metástases no pulmão e fígado (Figura 32). Na tanatoscopia, 24 horas após o óbito de dois animais do grupo controle negativo (G1), que foi a óbito no $44^{0}$ dia após inoculação dos outros grupos tumores, revelaram fenômenos abióticos consecutivos transformativos (autólise, putrefação, maceração, mumificação e saponificação). Nesses animais, não outras outras alterações.

No grupo G3 (tratamento com MHT e NPsel + NPcit), a sobrevida foi expressivamente maior: um animal veio a óbito no $83^{\circ}$ dia, três no $88^{\circ}$, e um animal ainda permanecia vivo até 160 dias (em 10/12/2015). As análises histopatológicas dos órgãos dos animais que morriam,apresentaram-se sem alterações, tanto nos fragmentos dos órgãos, como na rede linfonodal, denotando cura do tumor.

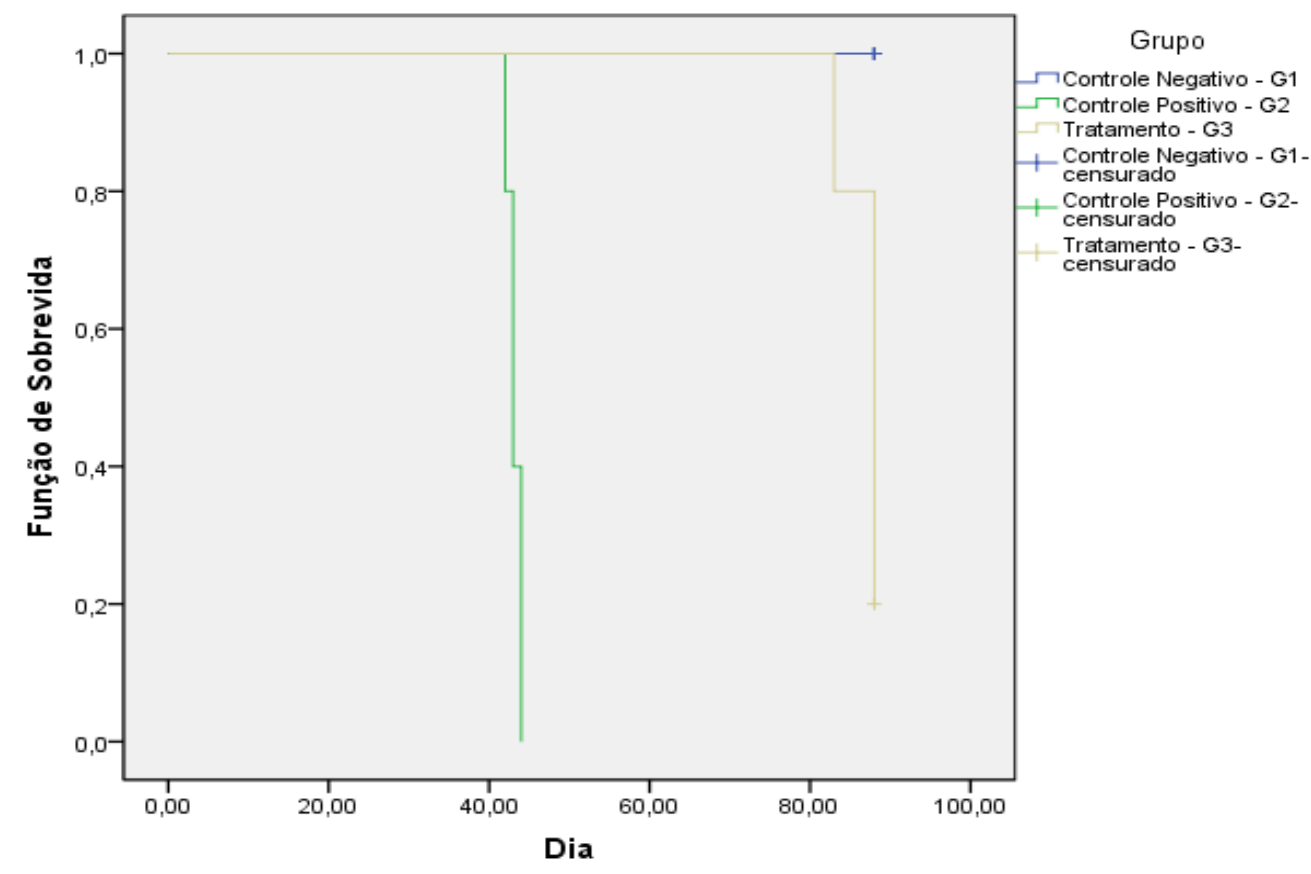

Figura 25: Sobrevida. G, recebeu solução salina a $0.9 \%, \mathrm{G} 2$, controle tumor, G3, TE $+\mathrm{MHT}+\mathrm{NPcit}+\mathrm{NPsel}$ e G3 grupos que foram a óbito, encerrou o tratamento ou permanecem vivos. 




Figura 26: Histologia de um animal do grupo sobrevida G2: (A) Êmbolo em vaso linfático no interior do fígado e detalhe (B) mostrando intenso pleomorfismo celular das células tumorais (C) Vista panorâmica do pulmão(D, E, F) Detalhe do parênquima pulmonar apresentando em vaso linfático células tumorais que invadem o tecido pulmonar; coloração HE. 


\section{DISCUSSÃO}

Este trabalho foi desenvolvido com o objetivo de tratar câncer mamário obtido ortotopicamente por duas terapias combinadas, magnetohipertermia e quimioterapia, ambas baseadas em materiais nanoestruturados. Para a magnetohipertermia foi usado o fluido magnético NPcit, constituído de nanopartículas de maghemita recobertas com citrato, enquanto para a quimioterapia, nanocápsulas de PLGA contendo Selol. Nanocápsulas magnéticas contendo Selol já foram previamente desenvolvidas e testadas no tratamento de tumor mamário, tendo levado à redução de $70 \%$ do volume tumoral nas circunstâncias utilizadas (ESTEVANATO, 2012). No presente estudo optamos por ter duas nanoestruturas diferentes (NPcit e NPsel) para maior controle das condições experimentais.

Amostras similares ao fluido NPcit já foram empregadas por pesquisadores do grupo de Nanobiotecnologia da UnB, em testes pré-clínicos (BRUGIN, 2007; ESTEVANATO, 2012), tendo sempre revelado biocompatibilidade adequada para aplicações biomédicas. A biocompatibilidade, biodistribuição e eficácia das NPM são altamente dependentes das características físicas, em especial da natureza química, tamanho, cobertura e carga. Quanto à natureza química, as nanopartículas à base de óxidos de ferro, magnetita e maghemita, são as mais biocompatíveis e, dentre elas, as de maghemita são ainda melhores no que tange a biocompatibilidade (GARCIA, 2002; BRUGIN, 2007; PORTILHO, 2011). Da mesma forma, o diâmetro das nanopartículas de NPcit ( $8 \mathrm{~nm}$ por DRX ou $10 \mathrm{~nm}$ por MET, exibindo carga $-49 \mathrm{mV}$ ) está na faixa ideal para aplicações biomédicas (PORTILHO, 2011). As NPM desse fluido são pequenas o suficiente para atravessar membranas, ao mesmo tempo em que respondem ao campo magnético alternado elevando a temperatura, como demonstrado pelos testes de termografia.

Hipertermia é um termo utilizado para geração de calor relacionado à terapia antitumoral. Nesse sentido, o grau da temperatura na terapia para hipertermia pode ser classificada em: ablação térmica, quando o tumor é submetido a altas temperaturas, acima de $46^{\circ} \mathrm{C}$, o que provoca necrose tecidual direta, coagulação ou carbonização; diatermia, temperaturas baixas, menor que $41^{\circ} \mathrm{C}$, usada para o tratamento de doenças reumáticas em fisioterapia; e hipertermia moderada, temperaturas em torno de $41^{0} \mathrm{C}$ a $46^{0} \mathrm{C}$, termo tradicionalmente designado como tratamento de hipertermia, com vários 
efeitos, tanto nos níveis celulares como teciduais (HILDEBRANDT, 2002; SANTOSGOLDSTEIN 2003; MARQUES, 2006; NAGARAJAN, 2008).

Considerando estes dados, com o propósito de realizar a hipertermia, o volume de $110 \mu \mathrm{L}$ da amostra NPcit foi selecionado para os experimentos de MHT, por ter alcançado a temperatura de $42,6^{\circ} \mathrm{C}$ nos primeiros quatro minutos e ter mantido estável a temperatura de $43,7^{\circ} \mathrm{C}$ por uma hora, proporcionando assim, características térmicas ideais para a terapia de MHT.

Sob efeito da hipertermia, as células tumorais sofrem estresse, resultando na ativação e/ou iniciação de vários mecanismos de desagregação intra e extracelulares. Dentre esses mecanismos, podem ser citados a desnaturação das proteínas, indução e regulação da apoptose, transdução de sinal, multirresistência e proteínas de choque térmico (Hsp). Já nos níveis teciduais, são mudanças de pH, perfusão e oxigenação do microambiente (HILDEBRANDT, 2002; SANTOS-MARQUES, 2006; GOLDSTEIN 2003; NAGARAJAN, 2008). Assim sendo, diminui a viabilidade das células tumorais, uma vez que estas são menos resistentes a aumentos bruscos de temperatura do que as células normais circunvizinhas (TARTAJ, 2003; TORCHILIN, 2007; ANKAMWAR et al., 2010; LAURENT et al., 2011; CASTRO, 2010; CONDE et al, 2012; COLOMBO et al., 2012). Em concordância, em nossos experimentos foi observada diminuição do volume tumoral (ainda que muitas vezes não significativa em relação ao controle tumor) após tratamento com a MHT.

A implantação do tumor e as várias modalidades de tratamento podem causar, no sangue, alterações do número de células e das taxas dos componentes não celulares (SOLBERG e CPETITCLERC, 1988; EVERDS, 2007; FERREIRA e ANDRIOLO, 2008; WEISS e WARDROP, 2010; BRANCO, 2011; ARAÚJO, 2012). Dessa forma o hemograma completo é um dos exames requisitados mais frequentemente para avaliar e quantificar os componentes celulares do sangue (eritrócitos, leucócitos e plaquetas), sendo ferramenta importante em análises patológicas, uma vez que permite identificar anemias, processos inflamatórios, alérgicos, parasitológicos e distúrbios na coagulação sanguínea (GARCIA, 2002; EVERDS, 2007). A esse respeito, os tratamentos com NPsel e MHT+NPsel foram eficazes em normalizar as alterações do eritrograma promovidas pelo tumor. Isto provavelmente foi decorrente não só da ação antioxidante do Selol, mas também de sua ação antitumorigênica, particularmente quando esta ação esta associada ao tratamento com magnetohipertermia. Tal sugestão é corroborada pelos 
resultados do leucograma, bioquímicos, bem como por aqueles obtidos com o volume tumoral.

O tipo de leucócito mais comumente encontrado no sangue periférico de camundongos é o linfócito, constituindo aproximadamente $3 / 4$ da população, seguido da população de neutrófilos (THRALL et al., 2007). Como os linfócitos são uma população heterogênea de células de importância crítica nas respostas imunes (THRALL et al., 2007) e a imunidade reduzida dependente de linfócitos pode favorecer a carcinogênese (MIRANDA-VILELA et al., 2013 e 2014), o aumento deste tipo de imunidade foi provavelmente responsável pela inibição mais eficaz do crescimento tumoral promovido pelo tratamento combinado com MHT+NPsel. Além disto, o processo inflamatório promovido por tal tratamento poderia também contribuir para uma melhor resposta imune. Isto porque os neutrófilos são responsáveis pela fagocitose de pequenas partículas e pela modulação da resposta imune (EVERDS, 2007). Estas células participam da resposta inflamatória por meio de quimiotaxia positiva ao tecido inflamado e fagocitose (THRALL et al., 2007), sendo implicadas na liberação de citocinas inflamatórias, mediadores lipídicos e enzimas capazes de promover dano tecidual, neste caso, no tumor (COSTA et al., 2009).

Sabe-se que o selênio é um composto que faz parte da enzima glutationa peroxidase, a qual protege as células contra danos oxidativos. Diversos trabalhos já mostraram que pequenas quantidades de selênio adicionadas na alimentação reduzem o risco do aparecimento de tumores em órgãos como a próstata, colon, reto, estômago, fígado e pulmão (WHANGER, 2004; GROMADZINSKA et. al., 2007). Estudos de fase clínica também mostraram que pacientes com câncer de ovário submetidas à quimioterapia e que tiveram uma suplementação com selênio tiveram aumento da atividade da enzima glutationa peroxidase nos eritrócitos após 2 e 3 meses de suplementação. Além disso, no mesmo período, houve diminuição significativa de efeitos colaterais da quimioterapia como perda de cabelo, flatulência, dor abdominal, fraqueza e perda de apetite (SIEJA e TALERCZYK, 2004).

Não se conhece o exato mecanismo de ação do selênio, mas tem sido proposto que ele exerce sua ação antitumorigênica por meio de atividades antiandrogênicas, efeitos de inibição do crescimento através da regulação de p53, danos no DNA e apoptose, sendo este último o mecanismo mais aceito na literatura (GROMADZINSKA et. al., 2007). Compostos que contêm selênio no seu nível de oxidação +4 possuem elevada atividade como um sequestrador de radicais livres e, consequentemente, como 
um agente antitumoral (SUCHOCKI et. al., 2007). O Selol é um composto orgânico sintetizado a partir de selenitotriglicerideos, os quais possuem selênio +4. SUCHOCKI et al. (2007) mostraram que o Selol tornou sensíveis células leucêmicas resistentes a quimioterápicos antineoplásicos, indicando que este composto poderia ser utilizado como agente quimiosensibilizador no tratamento do câncer. Foi demonstrado também que a administração de Selol por via subcutânea ou intraperitoneal em ratos apresentou toxicidade extremamente baixa (JASTRZEBSKI et. al., 1995), corroborando nossos resultados.

Evidências crescentes sugerem que as células cancerosas estão sob crescente estresse oxidativo em comparação com as células normais, e isso está relacionado à transformação oncogênica, ao aumento da atividade metabólica, ao mau funcionamento mitocondrial e ao aumento da geração de espécies reativas de oxigênio (ERO) (MIRANDA-VILELA et al., 2014). Devido às atividades reduzidas das enzimas antioxidantes em uma ampla variedade de tumores, a administração antioxidante pode ajudar o sistema antioxidante e inibir o crescimento do tumor, reduzindo a produção de espécies reativas de oxigênio (ERO) (MIRANDA-VILELA et al., 2011. Por outro lado, diferentes níveis de estresse oxidativo parecem induzir diferentes resultados em células cancerosas, onde o estresse oxidativo leve ativa mecanismos celulares de sinalização, como proliferação, migração e invasão, mas o estresse oxidativo alto pode induzir a morte celular (MIRANDA-VILELA et al., 2014). Neste contexto, apesar de os tratamentos com MHT e NPsel terem reduzido significativamente a percentagem de fragmentação do DNA em relação aos controles negativo e tumor, enquanto para o tratamento combinado MHT+NPsel tal redução foi apenas em relação ao controle negativo, este último tratamento foi mais eficiente em reduzir o volume tumoral, corroborando os dados da literatura.

Juntamente com o hemograma, a enzimologia clínica é uma importante ferramenta de investigação que conduz ao diagnóstico de enfermidades de animais, oferecendo o máximo de informação com um mínimo de invasibilidade (QUIMBY e LUONG, 2007). Diferentes órgãos, tecidos ou células contêm diferentes enzimas. Em alguns casos, apenas poucos órgãos ou tecidos contêm uma determinada enzima. Essa enzima, chamada tecido-específica, tende a ser útil como teste diagnóstico (THRALL, 2007). Em adição, a avaliação de parâmetros bioquímicos do soro é fundamental para identificar a possível ocorrência de toxicidade induzida por um novo fármaco, e deve ser correlacionada com testes histopatológicos (RAMAIAH, 2007). Injúrias hepáticas 
compõem mais de $50 \%$ das manifestações de toxicidade causadas por agentes químicos (SCHEARS, 2003), representando o maior obstáculo para o desenvolvimento de novos fármacos (CULLEN e MILLER, 2006). Assim, os níveis séricos de bilirrubina, TGO, TGP (transaminase glutâmica pirúvica), gama glutamil transferase e fosfatase alcalina foram usados para avaliar possíveis disfunções no sistema hepatobiliar (SUTHERLAND, 1989; QUIMBY e LUONG, 2007) decorrente da implantação do tumor e/ou tratamentos, enquanto a creatinina sérica e ureia foram usadas como ensaios de função renal (QUIMBY e LUONG, 2007), e os resultados foram comparados com análises histopatológicas dos órgãos.

A bilirrubina é produto da degradação da hemoglobina por células do sistema mononuclear fagocitário. É conjugada no fígado para depois ser eliminada na bile, e sua análise é útil para o diagnóstico diferencial de doenças hepáticas e biliares, além de outras causas de icterícia. A bilirrubina indireta (ou não conjugada) é uma molécula insolúvel em água que é transportada no sangue ligada à albumina. Percorre a corrente sanguínea até o fígado, onde é conjugada com o ácido glucurônico (glucoronidação) para produzir a forma solúvel em água (bilirrubina direta ou conjugada) (QUIMBY e LUONG, 2007). Níveis elevados de bilirrubina não conjugada (indireta) são usualmente observados em situações de lise aumentada de eritrócitos e também em doenças nas quais a captação, a conjugação e a secreção de bilirrubinas estão diminuídas, enquanto níveis elevados de bilirrubina conjugada (direta) estão associados à colestase intrahepática ou obstrução do ducto biliar extra-hepático (THRALL, 2007). Neste sentido, nossos resultados corroboram aqueles do eritrograma, indicando que, se ocorreu hemólise, esta não foi suficiente para aumentar os níveis de bilirrubina total e indireta, mesmo no grupo controle tumor, que promoveu redução significativa de hemácias, porém dentro dos valores de referência. Visto que não foi observada nenhuma alteração hepática ao nível histológico em nenhum dos grupos, os resultados da histopatologia corroboram os níveis séricos reduzidos de bilirrubina direta.

A transaminase glutâmica-oxalacética (TGO) ou aspartato aminotransferase (AST) é encontrada no citoplasma e nas mitocôndrias de muitas células, principalmente do fígado, coração, músculos esqueléticos, rins, pâncreas e eritrócitos (DEWAR et al., 1958), enquanto a transaminase glutâmica-pirúvica (TGP) ou alanina aminotransferase (ALT) é encontrada em altas concentrações apenas no fígado. Consequentemente, níveis séricos aumentados dessas enzimas servem como indicativos de lesão celular (BRUCE et al., 1958; DEWAR et al., 1958; ALMERSJÕ, 1968; CHALIFOUX e LAGACÉ, 
1969). Nesse aspecto, o tratamento combinado MHT+NPsel foi o único que não aumentou significativamente os níveis séricos de TGO em relação aos animais saudáveis, além de manter níveis normais de TGP, sugerindo uma melhoria da situação de hepatotoxicidade relacionada à necrose de hepatócitos e à inflamação (CENTER, 2007) provocada pelo tratamento com o paclitaxel.

A gama glutamil transferase (GGT) é sintetizada por quase todos os tecidos corporais, com maior concentração no pâncreas e nos rins e menor concentração nos hepatócitos, no epitélio de ductos biliares e na mucosa intestinal. No entanto, a maior parte da GGT sérica é oriunda do fígado (THRALL, 2007). Isto porque, quando a GGT é liberada pelas células pancreáticas, aparentemente a maior parte da enzima é excretada junto com a secreção pancreática, em vez de ser transferida ao sangue, enquanto a de origem renal é excretada na urina (THRALL, 2007; VIDAL et al., 2009). Já a fosfatase alcalina (ALP) é uma enzima sintetizada no fígado, nos osteoblastos e nos epitélios intestinal e renal; porém os hepatócitos respondem pela maior parte de sua atividade normal (THRALL, 2007). Desta forma, aumentos séricos de GGT e/ou de ALP podem ser indicativos de colestase, lesão hepática de caráter inflamatório ou hepatotoxicidade (CENTER, 2007; THRALL, 2007; VIDAL et al., 2009). Frente a esses parâmetros bioquímicos, pode-se sugerir ausência de hepatotoxicidade, corroborando nossos resultados histopatológicos do fígado.

A ureia é produzida no fígado como produto residual do catabolismo de proteínas e tradicionalmente, sua concentração é medida em termos de nitrogênio da ureia (QUIMBY e LUONG, 2007). O nitrogênio da ureia sanguínea (NUS) é um dos parâmetros bioquímicos tradicionalmente utilizados na avaliação da filtração glomerular. Portanto, a diminuição da taxa de filtração glomerular ocasiona aumento no valor de ureia (NUS). Também, o NUS é influenciado pela taxa de produção hepática de ureia e pela taxa de excreção renal e extrarrenal. Fatores que aumentam a produção de ureia no fígado, por exemplo, provocam elevação da concentração sérica de ureia, podendo ocorrer aumento de NUS. Por outro lado, uma doença hepática grave o suficiente para prejudicar a capacidade funcional do fígado pode ocasionar taxa anormal de desaminação de aminoácidos e ureagênese baixa. Nesse caso, uma diminuição no valor de NUS pode ser considerada um indicador de doença hepática grave (THRALL, 2007). Apesar da redução significativa de ureia que observamos no controle positivo e os tratamento com NPsel e MHT+NPsel, os valores estavam dentro dos limites de referência reportados para camundongos (21-53 mg/dL) (QUIMBY e LUONG, 2007), 
sugerindo a não existência de lesão hepática ou renal e corroborando novamente os resultados de ausência de alterações histopatológicas no fígado e nos rins. Tal sugestão é suportada pelos resultados discutidos acima e pelos resultados não-significativos da creatinina, molécula formada a partir da condensação e desidratação espontânea de creatinina muscular, que é excretada quase exclusivamente por via renal durante a filtração glomerular (THRALL, 2007). A depuração de substâncias exógenas administradas ao organismo é realizada nos rins e, devido à velocidade constante de excreção de creatinina, sua concentração no sangue é um excelente parâmetro para determinar a taxa de filtração glomerular e, deste modo, relacionar com a possível nefrotoxicidade causada pelos tratamentos realizados (MOTTA, 2003).

O ferro é o principal constituinte da hemoglobina, sendo transportado pelo sangue associado à transferrina na forma de ferro sérico (EVERDS, 2007; WANG et al, 2011). Visto que, tanto a redução do número de hemácias quanto a deficiência de ferro podem ocasionar anemia, os níveis de ferro sérico e de transferrina foram dosados para avaliar possíveis alterações decorrentes da presença do tumor ou dos tratamentos. Haja vista que a implantação do tumor provocou redução significativa de hemácias, HCM e CHCM, a redução significativa de ferro sérico já era esperada. Isto porque, enquanto HCM indica a quantidade média de hemoglobina dentro de uma hemácia, CHCM indica a concentração média desta molécula no interior das células vermelhas (em relação a 1 dL de eritrócitos) (ZAGO et al., 2004). Sendo assim, os resultados sugerem que o tratamento combinado MHT+NPsel foi eficaz em normalizar os níveis séricos de ferro e possivelmente facilitar a sua liberação para as células, uma vez que este papel é também atribuído à transferrina (CRICHTON et al., 2002; GROTTO, 2008), cujos valores aumentaram significativamente após este tratamento.

A implantação do tumor de Ehrlich tem sido relacionada a uma discreta anemia normocítica, mesmo não tendo sido observada diferença estatística em relação ao eritrograma (VERÇOSA-JUNIOR et al., 2004). Este tipo de anemia está associado a várias doenças inflamatórias, incluindo traumatismos, infecções e neoplasias, sendo normalmente discreta e moderada (THRALL et al., 2007). Devido ao fato de que, ao contrário dos seres humanos e muitos outros animais, o baço de camundongos é o principal local da hematopoiese juvenil e do adulto normal, a anemia provocada pela instalação do tumor, mesmo que discreta, poderia explicar o aumento significativo do baço observado nos animais inoculados. Neste contexto, os tratamentos com Npsel, sozinho ou combinado, apesar de retornarem os valores do eritrograma à normalidade, 
mantiveram aumento significativo do peso do baço em relação ao controle negativo. Este aumento poderia estar correlacionado à existência, no baço de camundongos, de leucócitos em diversos estados de maturação. Outro fator que poderia estar relacionado com a função hematopoiética é o maior número de megacariócitos que sofrem maturação no baço desta espécie (VERÇOSA JÚNIOR et al., 2004).

Segundo o Instituto Oncológico de Ribeirão Preto (InORP, 2015) e da SILVA (2013), o estudo da sobrevida é o parâmetro mais utilizado para avaliar os resultados na área oncológica, (InORP, 2015; da SILVA, 2013). Posto isto, e com base nos resultados de cura observados, foi realizado neste estudo a análise de sobrevivência de três grupos: controle negativo, controle tumor, e tratamento combinado MHT+NPsel, a fim de validar o potencial terapêutico dessa etapa, determinar os preditores, tamanho do tumor e invasão linfática. Foi possível observar no experimento de sobrevida, que no grupo controle tumor todos animais foram a óbito aos 45 dias, apresentaram graus severos de acometimento nos linfonodos jejunal, traqueobraquial, renal, mesentérico, mediastino cranial, gástrico, pancreaticojujenal e cólico (KAWASHIMA et al; 1964; VAN DEN BROECK et al, 2006), e foram detectadas metástases no pulmão e fígado. Nos animais com o tratamento combinado de NPsel e MHT (NPcit + campo AC) tiveram aumento de sobrevida de 45 dias para 83 dias de quatro animais e dois animais permanecem vivos, 180 dias depois, em estado hígido, assim como não foram detectados acometimentos dos linfonodos e órgãos.

Nos estudos de Kiseleva (1972), Dagli (1992) e de Silva (2004), os autores consideraram o tumor de Ehrlich como modelo adequado para o estudo da disseminação linfática em camundongos, o que valida os achados do nosso estudo. No entanto, os mesmos pesquisadores preconizam que não há evidências de que o TE seja metastático para os órgãos torácicos e abdominais. Em desacordo, o presente estudo evidenciou a ocorrência de metástase e que, após a terapia combinada proposta, 100\% dos animais ficaram livres de acometimento metastático na rede linfonodal e órgãos.

Corroborando nossos resultados, na investigação de sistemas nanoestruturados para o tratamento de câncer de mama combinado magnetohipertermia e Selol, esse ultimo como agente potencializador da eficácia terapêutica de quimioterápicos antineoplásicos; alguns mecanismos têm sido sugeridos para justificar o efeito anticarcinogênico do Selol. Dentre esses mecanismos, incluem o bloqueio do ciclo celular, indução da apoptose de células cancerígenas e inibição da angiogênese (SCHRAUZER, 2000; MILNER, 2001; SUCHOCKI et al, 2007; ESTEVANATO, 
2012); na potencialização da inibição do crescimento de 4-hidroxitamoxifeno $\left(10^{-7} \mathrm{~mol}\right.$ / L) em linhas celulares de câncer sensível ao tamoxifeno e MCF-7 de mama T47D (SHAH, 2005).

Já o calor gerado pelas NPM, ao serem submetidas a campo magnético de frequência alternada, tem a propriedade de ampliar a sobrevida de animais portadores de tumor, causar regressão tumoral ou, ainda, eliminá-lo (BRUSENTSOV, 2004; JORDAN, 2006).

Em síntese, este estudo mostrou que o modelo ortotópico de tumor de Ehrlich, desenvolvido e caracterizado durante a primeira etapa, é adequado para aprofundar os conhecimentos sobre a biologia do tumor, o comprometimento linfonodal no processo de metástase, para estudos da eficácia de novas terapias. $\mathrm{O}$ estudo mostrou ainda que o emprego de nanopartículas magnéticas e nanocápsulas com Selol na realização simultânea da magnetohipertermia e da quimioterapia promoveu a cura total do câncer mamário em camundongos, como demonstrado por análises histopatológicas e sobrevida dos animais. 


\section{CONCLUSÃO}

O conjunto de dados obtidos neste trabalho permitem concluir que:

- O modelo de tumor de mama ortotópico apresentado é adequado para os estudos da biologia do tumor, disseminação linfática e metástase em camundongos;

- Células TE frescas possibilitam o desenvolvimento de tumor detectável 24 horas após a inoculação;

- A inoculação de tumor ortotópico desencadeou quantidades significativas de interleucinas pró-inflamatórias, como a IL-1 $\beta$ e IL-17;

- A amostra magnética NPcit (nanopartículas de maghemita recobertas com citrato) apresentou características térmicas adequadas para a magnetohipertermia, quando exposta a campo magnético AC;

- Nas condições experimentais usadas, o equipamento de magnetohipertermia desenvolvido e patenteado pelo grupo (Magnetherm) apresentou eficácia mais significativa no tratamento do tumor de Ehrlich que o equipamento Magnetherm (CMag.);

- NPsel e MHT+NPsel foram eficazes em normalizar as alterações do eritrograma, hemograma e reduzir significativamente a percentagem de fragmentação do DNA promovidas pelo tumor, denotando sua atividade antioxidante;

- A terapia combinada nas condições experimentais deste estudo, foram eficazes em reduzir o crescimento tumoral e evitar metástases. 


\section{REFERÊNCIAS}

AABO K.; VINDEL $\varnothing V$, L. L.; SPANG-THOMSEN, M. Interaction between three subpopulations of Ehrlich carcinoma in mixed solid tumours in nude mice: evidence of contact domination. Br J Cancer, v. 70, n. 1, p. 91-96, 1994.

ABDEL-RAHMAN, M. N.; KABEL, A. M. Comparative study between the effect of methotrexate and valproic acid on solid Ehrlich tumour. J Egypt Natl Canc Inst, v. 24, n. 4, p. 161-167, 2012.

AKTAŞ, E. Ehrlich Asit Sıvısının L-Hücrelerinin Çoğalma Hızına Etkisi. Yüksek Lisans Tezi. İstanbul Üniversitesi Fen Bilimleri Enstitüsü. İstanbul. 1996.

ALANKO, A.; HEINONEN, E.; SCHEININ, T. et al: Significance of estrogen and progesterone receptors, disease-free interval, and site of first metastasis on survival of breast cancer patients. Cancer, v. 56, p. 1696-1700, 1985.

ALMERSJÔ, O.; BENGMARK, S.; ENGEVIK, L.; HAFSTRÖM, L. O.; LOUGHRIDGE, B. P.; NILSSON, L. A. Serum enzyme changes after hepatic dearterialization in man. Annals of Surgery, v. 167, n.1, p. 9-17, 1968.

ALTERMAN, A. L.; FORNABIO, D. M.; STACKPOLE, C. W. Metastatic dissemination of B16 melanoma: pattern and sequence of metastasis. J. Natl. Cancer Inst, v.75, p. 691$702,1985$.

ANDRADE, A.; PINTO, S. C.; OLIVEIRA, R. S. Animais de Laboratório: criação e experimentação. Rio de Janeiro, Fiocruz, 2002.

ANKAMWAR, B.; LAI, T. C.; HUANG, J. H.; LIU, R. S.; HSIAO, M.; CHEN, C. H.; HWU, Y. K. Biocompatibility of $\mathrm{Fe}_{3} \mathrm{O}_{4}$ nanoparticles evaluated by in vitro cytotoxicity assays using normal, glia and breast cancer cells. Nanotoxicology, v. 21, n. 7, 2010.

ANVISA Agência Nacional de Vigilância Sanitária. Guia para a condução de estudos não clínicos de toxicologia e segurança farmacológica necessários ao desenvolvimento de medicamentos. Brasília, 31 de janeiro de 2013.

ARAÚJO, F. T. M. Estabelecimento de valores de referência para parâmetros hematológicos e bioquímicos e avaliação do perfil imunológico de linhagens de camundongos produzidas nos biotérios do Centro de Pesquisas René Rachou I FIOCRUZ - Minas e do Centro de Criação de Animais de Laboratório / FIOCRUZ. 2012, 157 f. (Dissertação). Centro de Pesquisas René Rachou, Fundação Oswaldo Cruz, Belo Horizonte. 2012.

BAIOCHI, E.; BIGANHA, J. G.; EZEQUIEL, R.; FEDER, D. Estrógeno em Tumor de Ehrlich: Estudo da sobrevida e Avalição da Resposta Imunológica. Arq. Med. ABC, v. 9, p. 1-2, 1986. 
BARBOSA, L. S. Estudo dos processos de magnetohipertermia e terapia fotodinâmica mediados por magnetolipossomas fotossensibilizados em camundongos. 28 de março de 2008. Tese (Doutorado) - Universidade de Brasília, Brasília, 2008.

BARCELOUX, D. G.; SELENIUM. J. Toxicol. Clin. Toxicol, vol 37, p. 145-172, 1999.

BASKETT, C. K. V. L.; SPATE, J. S.; MORRIS, H. D.; ANDERSON, M. M.; MASON, C. L.; REAMS, T .P.; CHENG, K. R.; ZINN, G. M.; HILL, R. P.; DOWDY. J. Radioanal. Nucl. Chem. v. 195, p. 97-108, 1995.

BECK, J. W. Nanopartículas magnéticas metálicas recobertas com óxido de ferro: intensificação das propriedades magnéticas da nanopartícula e funcionalização para aplicação em biomedicina. 28 de fevereiro de 2011. Dissertação (Mestrado) - Instituto de Química de São Carlos, USP, São Paulo, 2011.

BECKETT, G. J. \& Arthur, J. R. Selenium and endocrine systems. Journal of endocrinology. v. 184, p. 455-465, 2005.

BEM, Ewa M. Determination of Selenium in the Environment and in Biological Material. Environmental Health Perspectives, v. 37, p. 183-200, 1981.

BENEVIDES, L.; CARDOSO, C. R. B.; TIEZZI, D. G. et al. Enrichment of regulatory T cells in invasive breast tumor correlates with the upregulation of IL-17A expression and invasiveness of the tumor. Eur J Immunol, v. 43, n.6, p. 1518-1528, 2013.

BIBBY M. C. Orthotopic models of cancer for preclinical drug evaluation: advantages and disadvantages. Eur J Cancer, v.40, n. 6, p. 852-857, 2004.

BICALHO, L. S. et al. Photodynamic Therapy Leads to Complete Remission of Tongue Tumors and Inhibits Metástases to Regional Lymph Nodes. Journal of Biomedical Nanotechnology, v. 9, p. 1-8, 2012.

BICALHO, L. S.; LONGO, J. P.; CAVALCANTI, C. E. et al. Photodynamic therapy leads to complete remission of tongue tumors and inhibits metastases to regional lymph nodes. J Biomed Nanotechnol, v. 9, n. 5, p. 811-818, 2013.

BRANCO, A. C. S. C. et al. Parâmetros Bioquímicos e Hematológicos de Ratos Wistar e Camundongos Swiss do Biotério Professor Thomas George. Revista brasileira de ciências da saúde. v. 15, n. 2, p. 209-214. 2011.

BRASIL Instituto Nacional de Câncer. ABC do câncer: abordagens básicas para o controle do câncer. 2 ed. Revista e atualizada. Rio de Janeiro: INCA, 2012. 134 p.

BRASIL, Ministério da Saúde. FALANDO SOBRE CÂNCER DE MAMA. Instituto nacional de câncer (INCA), Rio de Janeiro - RJ. 2012.

BRASIL. Ministério da Saúde. Caderno de Ação básica. Contole dos Cânceres do Colo do Útero e da Mama. Brasilia DF. 2013.

BRASIL. Ministério da Saúde. Secretaria de Gestão do Trabalho e da Educação na Saúde. Departamento de Gestão da Educação na Saúde. Curso de atualização em mamografia 
para técnicos e tecnólogos em radiologia / Ministério da Saúde, Secretaria de Gestão do Trabalho e da Educação na Saúde, Departamento de Gestão da Educação na Saúde. Brasília : Ministério da Saúde, 2014.

BRAZ, J.M. Efeitos das nanopartículas magnéticas a base de maguemita recobertas com ácido 2,3-dimercaptosuccínico em macrófagos de camundongos. Dissertação (Mestrado) - Instituto de Ciências Biológicas, Universidade de Brasília. Brasília, 2011.

BREHMER, J. S. Estudos de Extratos de Plantas Medicinais no Desenvolvimento do Tumor Ascítico de Ehrlich. Dissertação (Mestrado) - Universidade Do Vale do Itajaí. Itajaí, 2005.

BRUCE, R.; TODD, J. K.; LE DUNE, L. Serum Transaminase: Its Clinical Use in Diagnosis and Prognosis. British Medical Journal, v. 2, n. 5105, p. 1125-1128, 1958.

BRUGIN, A. Avaliação da Biocompatibilidade/Toxicidade de Fluido Magnético Composto de Nanopartículas de Maghemita Recobertas com Citrato em Camundongos Fêmeas Swiss. Dissertação (Mestrado) - Faculdade de Medicina, Universidade de Brasília. Brasília, 2007.

BRUSENTSOV, N. A.; KUZNETSOV, V. D.; BRUSENTSOVA, T. N.; GENDLER, T. S.; NOVAKOVA, A. A.; VOLTER, E. R.; HALIULINA, E. A.; DANILKIN, M. I. Magnetisation of ferrifluids and effects of intracellular deposition of ferrite nanoparticles. Journal of Magnetism and Magnetic Materials, v. 272-276, p. 23502351, 2004.

BUENO, V.; PESTANA, J. O. M. Revisão/Atualização em Transplante Renal: Xenotransplante. J. Bras. Nefrol. v. 18, n. 3, p. 302-306, 1996.

CAMPOS DA PAZ, M. L. Conjugação de anticorpo anti-antígeno carcinoembrionário a nanopartículas magnéticas: avaliação do potencial para detecção e tratamento de câncer. 2012. 163 f. Tese (Doutorado em Patologia Molecular) - Faculdade de Medicina, Universidade de Brasília, Brasília. 2012.

CARNEIRO, M. L. B. Efeitos biológicos de citrato de ródio (II) livre e associado a nanopartículas magnéticas e a magnetolipossomas em células de carcinoma mamário: estudos in vitro e in vivo. Tese (Doutorado) - Universidade de Brasília. Brasília, 2011.

CARVALHO, M. V. B.; MERIGHI, M. A. B. O cuidar no processo de morrer na percepção de mulheres com câncer: uma atitude fenomenológica. Rev. Latino-am. Enfermagem, v. 13, n. 6, p. 951-959, 2005.

CASTRO, P. B.; BRUNO, D. S.; FILHO, F. R.; FÉIIX., F. H. C.; PORTO.; LAVOR.; P. R.; F.; M. O. DE M. Avaliação da interferência da ciclosporina no desenvolvimento de metástases em um tumor de rato de baixa malignidade. Rev. Med. UFC. Fortaleza, v. 34, n. 1-2, 1994.

CASTRO, V. F.; CELESTINO, J.; QUEIROZ, A. A. A. De.; GARCIA, F. G. Propriedades magnéticas e biocompatíveis de nanocompósitos para utilização em magnetohipertermia. Revista Brasileira de Física Médica, v. 4, n. 1, p. 79-82, 2010. 
CENTER, S. A. Interpretation of liver enzymes. Veterinary Clinics Small Animal Practice, v. 37, p. 297-333, 2007.

CHALIFOUX, A.; LAGACÉ, A. Enzymes Sériques pour le Diagnostic de la Nécrose Hépatique Aigüe Expérimentale. Can. Journal of Comparative Medicine v. 33, n.3, p. 178- 186, 1969.

CHEKULAYEVA, L.; SHEVCHUK, I.; CHEKULAYEV, V. Influence of temperature on the efficiency of photodestruction of Ehrlich ascites carcinoma cells sensitized by hematoporphyrin derivative. Exp Oncol, v. 26, n. 2, p. 125-139, 2004.

CHEKULAYEVA, V. L.; SHEVCHUK, I. H.; CHEKULAYEV, V. A. Influence of Temperature on the Efficiency of Photodestruction by Ehrlich Ascites Carcinoma Cells Sensitized by Hematoporphyrin Derivative. Exp. Oncol Estonia: 2004.

CHIA, S.; NORRIS, B.; SPEERS, C. et al: Human epidermal growth factor receptor 2 overexpression as a prognostic factor in a large tissue microarray series of nodenegative breast cancers. J Clin Oncol, 2008

CHORILlI, M.; MICHELIN, D. C.; SALGADO, H. R. N. Animais de Laboratório: o camundongo. Revista de Ciências Farmacêuticas Básica e Aplicada, Araraquara, SP, Brasil. 2007.

CHOW, P. K. H.; et al. Using Animal Models in Biomedical Research. A Primer for the Investigator. WSPC, p. 308, San Diego, CA. 2008.

COLEMAN, M. P.; QUARESMA, M.; BERRINO, F.; LUTZ, J.M.; ANGELIZ, R.; CAPOCACCIA, R. Cancer survival in five continents: a worldwide population-based study. Lancet Oncol, v. 9, p. 730-756, 2008.

COLEMAN, R. E. Future directions in the treatment and prevention of bone metastases. Am J Clin Oncol. 2002;25: S32-8.

COLOMBO, M.; CARREGAL-ROMERO, et al. J. Biological applications of magnetic nanoparticles. Chem Soc Rev, v. 41, n. 11, p. 4306-4334, 2012.

CONDE, J.; DORIA, G.; BAPTISTA, P. Noble metal nanoparticles applications in cancer. $J$ Drug Deliv, p. 1-12, 2012.

COSTA, C. H. D.; RUFINO, R.; LAPA E SILVA, J. R. Células inflamatórias e seus mediadores na patogênese da DPOC. Rev Assoc Med Bras, v.55, p. 347-354, 2009.

COVELLI, V. Guide to the Necropsy of the Mouse. 2009. Disponível em: http://eulep.pdn.cam.ac.uk/Necropsy_of_the_Mouse/printable.php. Acesso em 24 de novembro de 2013.

CRICHTON, R. R.; WILMET, S.; LEGSSYER, R.; WARD, R. J. Molecular and cellular mechanisms of iron homeostasis and toxicity in mammalian cells. Journal of Inorganic Biochemistry, v. 91, n. 1, p. 9-18, 2002. 
CULLEN, J. M.; MILLER, R. T. The role of pathology in the identification of drug-induced hepatic toxicity. Expert Opin Drug Metab Toxicol, v. 2, n. 2, p. 241-247, 2006.

DA SILVA, L. E. et al. Efeito do Hipotireoidismo no Tumor de Ehrlich Sólido em Camundongos Fêmeas Castradas e Não Castrada. Arq Bras Endocrinol Metab. vol 48, 6 Dezembro 2004.

DA SILVA,C. J. F. L. et al. Avaliação do Crescimento do Tumor De Erlich em Camundongos Swiss Tratados com Melatonina. UFRPE, Recife. 2013.

DAGLI, M. L. Z. Disseminação Linfática do Tumor de Ehrlich: Estudo Experimental. Dissertação (Mestrado) - Universidade de São Paulo. São Paulo: USP. 1989.

DAGLI, M. L. Z.; GUERRA, J. L.; SALDIVA, P. H. N. An experimental study on the lymphatic dissemination of the solid Ehrlich tumor in mice. Braz J Vet Res Anim Sci, v. 29, p. 97-103, 1992.

De ASSIS, S.; WARRI, A.; CRUZ, M. I,; HILAKIVI-CLARKE, L. Changes in Mammary Gland Morphology and Breast Cancer Risk in Rats. J. Vis. Exp. 2010.

DE SOUZA, A. R.; COELHO, E. P.; ZYNGIER, S. B. Comparison of the anti-neoplastic effects of dirhodium(II) tetrapropionate and its adducts with nicotinate and isonicotinate anions in mice bearing Ehrlich tumors. Eur J Med Chem, v. 41, n. 10, p. 1212-1216, 2006.

DE SOUZA, L. R. et al. PVM/MA-shelled selol nanocapsules promote cell cycle arrest in A549 lung adenocarcinoma cells. Journal of Nanobiotechnology,p. 17. 2014.

DEIL, I. J.; SOLOMAYER, E. F.; BASTERT, G. Treatment of metastatic bone disease in breast cancer, bisphosphonates. Clin Breast Cancer, v. 1, p. 43-51, 2000.

DELMONICO, L. et al. A biologia do câncer de mama e testes moleculares de prognóstico. Revista HUPE, p. 7 (59-65), Rio de Janeiro, 2015.

DEVITA, V.; LAWRENCE, T.; ROSENBERG, S. Cancer Principles \& Practice of Oncology. 8th ed, ed. Lippincott Williams \& W ilkins. Yale Cancer Center, Yale University School of Medicine, New Haven Connecticut. 2008.

DEWAR, H. A.; ROWELL, N. R.; SMITH, A. J. Serum glutamic oxalacetic transaminase in acute myocardial infarction. British Medical Journal v. 2 n. 5105, p. 1121-1125, 1958.

DINIZ, D. G. A. Obtenção, caracterização e avaliação da citotoxicidade sobre células neoplásicas da isotretinoína encapsulada em lipossomas e nanocápsulas poliméricas. Tese (Doutorado) - Faculdade de Ciências da Saúde. Universidade de Brasília, Brasília, 2008.

DOOLDENIYA, M. D.; WARRENS A. N. Xenotransplantation: Where are we today? Journal of the Royal Society of Medicine, v. 96, p. 111-117, 2003. 
DU, J. W.; XU, K. Y., FANG, L. Y. et al. Interleukin-17, produced by lymphocytes, promotes tumor growth and angiogenesis in a mouse model of breast cancer. Mol Med Rep, v. 6, n. 5, p. 1099-1102, 2012.

DURAN, N.; LUIZ, H.; CAPPARELLI, M.; DE MORAIS, P. C. Nanotecnologia: introdução, preparação e caracterização de nanomateriais e exemplos de aplicação. São Paulo: Artiliber Editora, 2006.

DUTRA-DE-OLIVEIRA, J. E.; MARCHINI, S. J. Ciências Nutricionais. São Paulo: Sarvier, 1998. 203 p.

EBCTCG. EARLY Breast Cancer Trialists' Collaborative Group: Effects of chemotherapy and hormonal therapy for early breast cancer on recurrence and 15-year survival: An overview of the randomised trials. Lancet, v. 365, p. 687-1717, 2005.

EHRLICH, P. Experimentally carcinomstudien an Mäusen. Arb Inst Exp Ther Frankfurt, v. 1, p. 78-80, 1906.

EHRLICH, P.; APOLANT, H. Beobachtungen Über Maligne Mausentumoren. Berlin. Klin. Wschr., v. 28, p. 871-874,1905.

EISENBERG, A. L.; KAIFMAN, S. Câncer de mama: marcadores tumorais. Revista Brasileira de Cancerologia, p. 12, 47 (4), Rio de Janeiro, 2001.

ELMORSI, Y. M. et al. Effect of Ketoprofen and Indomethacin on Methotrexate Pharmacokinetics in Mice Plasma and Tumor Tissues. Journal of Applied Pharmaceutical Science v. 2, n. 6, p. 90-95, 2012.

ERALP, Y. et al. Doxorubicin and paclitaxel enhance the antitumor efficacy of vaccines directed against HER 2/neu in a murine mammary carcinoma model, 2004.

ESSNER, R. Sentinel Lymph Node Biopsy and Melanoma Biology. American Association for Cancer Research, 2006.

ESTEVANATO, L. L. C; LACAVA, L. M.; CARVALHO, L. C.; AZEVEDO, R. B.; SILVA, O.; PELEGRINI, F.; BÁO, S. N.; MORAIS, P. C.; LACAVA, Z. G. Long-term biodistribution and biocompatibility investigation of dextran-coated magnetite nanoparticle using mice as the animal model. J Biomed Nanotechnol, v. 8, n. 2, p. 301308, 2012.

ESTEVANATO, L. L. C.; CINTRA, D.; BALDINI, N.; PORTILHO, F.; BARBOSA, L.; MARTINS, O.; LACAVA, B.; MIRANDA-VILELA, A. L.; TEDESCO, A. C.; BÁO, S.; MORAIS, P. C.; LACAVA, Z. G. Preliminary biocompatibility investigation of magnetic albumin nanosphere designed as a potential versatile drug delivery system. Int J Nanomedicine, v. 6, p. 1709-1717, 2011.

EVERDS, N. E. Hematology of the Laboratory Mouse. In: Fox JG, Barthold SW, Davisson MT, Newcomer CE, Quimby FW, Smith AL (eds) The Mouse in Biomedical Research: Normative Biology, Husbandry, and Models., vol III. Elsevier, San Diego, California, USA, p 133-170, 2007. 
EVERDS, N. E. Hematology of the laboratory mouse. The Mouse in Biomedical Research, 2a ed., Elsevier, capítulo 5, p. 133-170. 2007.

BEHBOD, F. et al. An intraductal human-in-mouse transplantation model mimics thesubtypes of ductal carcinoma in situ. Breast Cancer Research, USA. 2009.

FCF-IQ/USP, Manual de Cuidados e Procedimentos com Animais de Laboratório do Biotério de Produção e Experimentação. São Paulo. 2013.

FELDMAN, B. F.; ZINKL, J. G.; JAIN, N. C. Schalm's Veterinary Hematology. 5th ed. Baltimore:146 Lippincott Willians \& Wilkins; 2000.

FERREIRA, C. E. S.; ANDRIOLO, A. Intervalos de referência no laboratório. J Bras Patol Med Lab. Fev; 44(1): 11-16. 2008.

FESSI, H. A. ; F. PUISIEUX A. ; J.PH. DEVISSAGUET L. ;N. AMMOURY AND S. BENITA. Nanocapsule formation by interfacial polymer deposition following solvent displacement. International Journal of Pharmaceutics, 1989.

FIGUEIREDO, L. C. Sistemas magnéticos nanoparticulados à base de maghemita. Tese (Doutorado) - Instituto de Física, Universidade de Brasília. Brasília, 2009.

FILHO, R. S. O. Experimental model in rat for sentinel node biopsy. Acta Cir Bras. v. 18, 2003.

FISHER, B.; BAUER, M.; WICKERHAM, D. L.; REDMOND, C. K.; FISHER, E. R. Relation of Number of Positive Axillary Nodes to the Prognosis of Patients With Primary Breast Cancer. American Cancer Society, v. 52, p. 1551-1557, 1983.

FOSTER, L. H.; SUMAR, S. Selenium in health and disease: a review. Critical Reviews in Food Science and Nutrition, v. 37, p. 211-228, 1997.

GARCIA, V. A. P. Avaliação da biocompatibilidade/toxicidade e biodistribuição de fluido magnético estabilizado por ácido cítrico e de magnetolipossomas convencionais em camundongos. Tese (Doutorado) - Programa de Pós-Graduação em Patologia Molecular - Faculdade de Ciências da Saúde, Universidade de Brasília. Brasília, 2002.

GIBBS, W.W. Desvendando as raízes do câncer. Scientifc American, v. 2, n. 15, p. 39-47, 2003.

GLINSKII, A. B.; SMITH, B. A.; JIANG, P. et al. Viable circulating metastatic cells produced in orthotopic but not ectopic prostate cancer models. Cancer Res, v. 63, p. 4239-4243, 2003.

GONTIJO, A. M. M. C; TICE, R. Teste do cometa para a detecção de dano no DNA e reparo em células individualizadas. In: Ribeiro LR, Salvadori DMF, Marques EK (Org). Mutagêneses ambiental. Canoas/RS, Ed. Ulbra, p. 247-279. 2003.

GRABOWSKI, F.; SUGHOCKI, 1995 P. Patente (Pol. PI 176530) (CL. A61K31/095), Varsóvia: Polônia, 30 Junho 1999. 
GROMADZINSKA, J.; RESZKA, E.; BRUZELIUS, K.; WASOWICZ, W.; AKESSON, B. Selenium and cancer: biomarkers of selenium status and molecular action of selenium supplements. Eur J Nutr, v. 47, n. 2, p. 29-50, 2007.

GROTTO, H. Z. W. Metabolismo do ferro: uma revisão sobre os principais mecanismos envolvidos em sua homeostase. Revista Brasileira de Hematologia e Hemoterapia, v. 30, n. 5, p. 390-397, 2008.

GUEDES, M. H. A.; GUEDES, M. E. A.; MORAIS, P. C.; da SILVA, M. F.; SANTOS, T. S.; ALVES Jr, J. P.; BERTELLI, C. E.; AZEVEDO, R.B.; LACAVA, Z.G.M. Proposal of a magnetohyperthermia system: preliminary biological tests, Journal of Magnetism and Magnetic Materials, v. 272-276, p. 2406-2407, 2004.

GUERRA, J. L. Aspectos do processo inflamatório em camundongos portadores do tumor de Ehrlich. Tese (Doutorado) - USP. São Paulo, 1983.

HILDEBRANDT, B.; WUST, P.; SREENIVASA, G.; et al. Hyperthermia in combined treatment of cancer. The cellular and molecular basis of hyperthermia. Critical Reviews in Oncology, v. 43, p. 33-56, 2002.

HÖFELMANN, D. A.; ANJOS, J. C.; AYALA, A. L. Sobrevida em dez anos e fatores prognósticos em mulheres com câncer de mama em Joinville, Santa Catarina, Brasil. Cien Saude Colet,19(6), p 1813-1824, 2014.

HOFFMAN, R. M. Orthotopic metastatic mouse models for anticancer drug discovery and evaluation: a bridge to the clinic. Invest New Drugs, v. 14, n. 4, p. 343-359, 1999.

Hyperther. 19 (2003) 373-384.

INCA. Instituto Nacional de Câncer. Estimativa 2012: incidência de câncer no Brasil. Rio de Janeiro: INCA, 2011.

INCA. Instituto Nacional do Câncer Estimativa 2014: Incidência de Câncer no Brasil / Instituto Nacional de Câncer José Alencar Gomes da Silva, Coordenação de Prevenção e Vigilância. Rio de Janeiro, INCA, p.124. 2014.

INCA. Instituto Nacional do Câncer. Tipos de câncer - mama. 2012. Disponível em http://www.inca.gov.br/wps/wcm/connect/tiposdecancer/site/home/mama. Acesso em 16 de maio de 2013.

inORP. Câncer de mama: análise de sobrevida. Disponível em: http://inorp.com.br/nossosresultados/indicadores-de-desempenho/cancer-de-mama-analise-de-sobrevida/. Acessado em 14/09/2015.

IRONS, R.; CARLSON, B.A.; HATFIELD, D.L.; DAVIS, C.D. Both selenoproteins and low molecular weight selenocoumpounds reduce colon cancer risk in mice with genétically impaired selenoprotein expression. J.Nutr. 136 (5), 1311-1317. 2006.

IRVIN, J. R. W.; MUSS, H. B.; MAYER, D. K. Symptom management in metastatic breast cancer. The Oncologist, v.16, p.1203-1214, 2011. 
JACKSON. Jackson Laboratory Disponível em: www.jaxmice.jax,org/strain/000648.html. acessado em 09/07/2015.

JANÁT-AMSBURY, M. M. et al. Combination of Local, Nonviral IL12 Gene Therapy and Systemic Paclitaxel Treatment in a Metastatic Breast Cancer Model, Salt Lake City, 2004.

JANDIAL, R. Metastatic Cancer Clinical and Biological Perspectives, Molecular Biology Intelligence Unit. Rio Grande, Austin, Texas 78701, USA, 2013.

JASTRZEBSKI, Z.; CZYZEWSKA-SZAFRAN, H.; FIJATEK, Z.; SUCHOCKI, P.; FITAK, B. A. Toxicity studies of a new selenium compound, selol, in rats. Drugs Exptl Clin Res, v. 21, n. 6, p. 217-220, 1995.

JEMAL, A. D. V. M.; BRAY, F.; FERLAY, J.; WARD, E.; FORMAN, D. et al. Global Cancer Statistics. Ca Cancer J Clin. 2011.

JIA, X.; YU, F.; WANG, J. et al. Emodin suppresses pulmonary metastasis of breast cancer accompanied with decreased macrophage recruitment and M2 polarization in the lungs. Breast Cancer Res Treat, 148(2):291-302. 2014.

JORDAN, A.; SCHOLZ, R.; MAIER-HAUFF, K.; LANDERGHEM, F. K. H. van; WALDOEFNER, N.; TEICHGRAEBER, U.; PINKERNELLE，J.; BRUHN， H.; NEUMANN, F.; THIESEN, B.; DEIMLING, A. von; Felix, R. The effect of thermotherapy using magnetic nanoparticles on rat malignant glioma. Journal of NeuroOncology, v. 78, p 7-14, 2006.

JUBB, K. V. F. e KENNEDY, N. C. Transmissible Veneral Tumor Canine. Pathology of Dosmestic Animals, n 3, p. 452. 1993.

JUNIOR, D. V.; MELO, M. M.; CASSALI G. D.; DANTAS-BARROS A. M. et al. Influência de agaricus blazei murrill sobre o tumor sólido de ehrlich e linfonodos poplíteos de camundongos. Arq. Bras. Med. Vet. Zootec., v.59, n.1, p.150-154. 2007.

JUNQUEIRA, L. C. \& CARNEIRO, J. Histologia Básica. 12ed. Rio de Janeiro: Guanabara Koogan, 2013.

KABEL, A. M. Effect of Combination between Methotrexate and Histone Deacetylase Inhibitors on Transplantable Tumor Model. Am J Med Studies,2(1), p 12-18. 2014.

KAMAT, A. M.; LAMM, D. L. Chemoprevention of urological cancer. The Journal of Urology, v. 161, n. 6, p. 1748-1760. 1999.

KAWASHIMA, Y.; SUGIMURA, M.; HWANG, Y. et al. The lymph system in mice. Jap J Vet Res, v.12, n. 4, p. 69-78. 1964.

KHANAM, J. A.; SULTAN, S.; HABIB, M. R.; ISLAM, M. R.; JESMIN, M.; SARKER, M.K.; ALI, M.M. Antineoplastic Activity of Bis-tyrosinediaqua Ni(II) Against Ehrlich Ascites Carcinoma. J. Pharm. Sci., v.7, n.1, p.33-37. 2008. 
KILLION, J.; RADINSKY, R.; FIDLER, I. Orthotopic Models are Necessary to Predict Therapy of Transplantable Tumors in Mice. Cancer Metastasis Rev, v.17, n.3, p.279284. 1998.

KIM, S. et al. Near-infrared fluorescent type II quantum dots for sentinel lymph node mapping. Nature Biotechnology, v. 22, n. 1, 2004.

MILNER, J. A.; MCDONALDS, S. S.; ANDERSON, D. E.; GREENWALD, P. Molecular Targets for Selenium im Cancer Prevention. Nutrition and cancer, v. 41, n.1 e2, p. 116. 2001.

KISELEVA, N. S.; MAGAMADOV, Y. C. Hematogenous dissemination of tumor cels and metastases formation in Ehrlich ascites tumor. Neoplasma, v. 19, n. 4, p. 257-275.1972.

KOCATÜRK, B.; VERSTEEG, H. H. Orthotopic Injection of Breast Cancer Cells into the Mammary Fat Pad of Mice to Study Tumor Growth.. J. Vis. Exp. v.96, ed. 51967, doi:10.3791/51967. 2015.

KORKAYA, H.; LIU, S.; WICHA, M. S. Breast cancer stem cells, cytokine networks, and the tumor microenvironment. J Clin Invest, v.121, n.10, p.3804-3809. 2011.

KRAUSE, S.; BROCK, A.; INGBER, D. E. Intraductal Injection for Localized Drug Delivery to the Mouse Mammary Gland. J. Vis. Exp., ed.50692, doi:10.3791/50692. 2013.

KSIAZEK, I. Z. A.; KAROLINA, S. et al Influence of Selol on the Expression of Oxidative Stress Genes in Normal and Malignant Prostate Cells. Cancer genomics \& proteomics, v.10, p.225-232. 2013.

KUBOTA, T. Metastatic models of human cancer xenografted in the nude mouse: the importance of orthotopic transplantation. J Cell Biochem. v.56, p.4-8. 1994.

KUMAR, C. S. S. R.; MOHAMMAD, F. Magnetic nanomaterials for hyperthermia-based therapy and controlled drug delivery. Advanced Drug Delivery Reviews, 2011.

GOLDSTEIN, L. S.; DEWHIRST, M. W.; REPACHOLI, M.; KHEIFETS, L. Summary, conclusions and recommendations: adverse temperature levels in the human body, Int. J. Hyperther. v.19, p.373-384. 2003.

LACAVA, B. M. Síntese de fluido magnético à base de maghemita para produção de nanocápsulas magnéticas de albumina bovina. Dissertação de Mestrado. Instituto de Química Universidade de Brasília. Brasília. 2009.

LACAVA, Z. G. M.; MORAIS, P. C. Aplicações biomédicas das nanopartículas magnéticas. Parcerias estratégicas, n.18, p.74-81, 2004.

LACAVA, L. M.; GARCIA, V. A. P.; KÜCKELHAUS, S.; AZEVEDO, R. B.; SADEGHIANI, N.; BUSKE, N.; MORAIS, P. C.; LACAVA, Z. G. M. Long-term 
retention of dextran-coated magnetite nanoparticles in the liver and spleen. Journal of Magnetism and Magnetic Materials. 2004.

LANDSKRON, L. M. F. Psicooncologia: As descobertas sobre o câncer ao longo da história. Porto Alegre, 2008.

LATARJET e LIARD, A. R. Anatomia Humana. Ed.2, São Paulo, Panamericana, 1993.

LAURENT, S.; MORTEZA, M. Superparamagnetic iron oxide nanoparticles: promises for diagnosis and treatment of cancer. Int J Epidemiol Mol Genet, v.2, n.4, p.367-390. 2011.

LETTRE, R.; PAWELETZ, N.; WERNER, D. Granzow C Sublines of the Ehrlich-Lettre Mouse Ascites Tumor, A New Tool for Experimental Cell Research. Naturwissenschaften, v.59, p.59-63. 1972.

LI, L.; Mori, S.; SAKAMOTO, M. et al. Mouse Model of Lymph Node Metastasis via Afferent Lymphatic Vessels for Development of Imaging Modalities. Plos ONE , v.8, n.2, e55797. 2013.

LIMA, E. D. R. D. P.; MAGALHÃES, M. B. B.; NAKAMAE, D. D. Aspectos ético-legais da retirada e transplante de tecido, órgãos e partes do corpo humano. Rev Latino Am Enfermagem, v.5, n.4, p.5-12. 1997.

London: TERMINOLOGY for nanomaterials. UK Department for Innovation, Universities and Skills (DIUS) British Standards Institution (BSI). 2007.

LUINI, A.; AGUILAR, M.; GATTI, G. et al. Metaplastic carcinoma of the breast, an unusual disease with worse prognosis: the experience of the European Institute of Oncology and review of the literature. Breast Cancer Res Treat, v.101, p.349-353. 2007.

LUO, H.; WANG, F.; BAI, Y.; CHEN, T.; ZHENG, W. Selenium nanoparticles inhibit the growth of HeLa and MDA-MB-231 cells through induction of Sphase arrest. Colloids Surf B Biointerfaces, v.94, p.304-308. 2012.

LYMAN, G. H.; TEMIN, S.; EDGE, S. B. et al. Sentinel Lymph Node Biopsy for Patients With Early-Stage Breast Cancer: American Society of Clinical Oncology Clinical Practice Guideline Update. J Clin Oncol. p.3-24. 2014.

SANTOS-MARQUES, M. J.; CARVALHO, F.; SOUSA, C.; REMIAO, F.; VITORINO, R.; AMADO, F.; FERREIRA, R.; DUARTE, J. A.; BASTOS, M. L. Cytotoxicity and cell signalling induced by continuous mild hyperthermia in freshly isolated mouse hepatocytes, Toxicol- ogy, v.224, p.210-218. 2006.

MADER, J. S.; HOSKIN, D. W. Cationic Antimicrobial Peptides Cytototoxic Agente for Cancer Traetament. Experct Opin Investig Drugs, v.15, p.933-946. 2006.

MADY, E. A. Antitumor and biochemical effects of Echis coloratus Crude venon on Ehrlich ascite carcinoma cells in vivo. J. Venon Anim. Toxins, v.8, p.283-296. 2002. 
MANSEL, R. E.; FALLOWFIELD L.; KISSIN, M. et al. Randomized Multicenter Trial of Sentinel Node Biopsy Versus Standard Axillary Treatment in Operable Breast Cancer: the almanac trial. J Natl Cancer Inst, v.98, n.9, p.599-609. 2006.

MANSEL, R. E.; FALLOWFIELD, L.; KISSIN, M.; GOYAL, A.; NEWCOMBE, R. G.; DIXON, J. M. Randomized Multicenter Trial of Sentinel Node Biopsy Versus Standard Axillary Treatment in Operable Breast Cancer: the almanac trial. Journal of the National Cancer Institute, v. 98, n. 9, 2006.

MASSO-WELCH, P. A.; DARCY, K. M.; STANGLE-CASTOR, N. C.; Margot, M. I. A developmental athas of rat mammary gland histology. Journal of Mammary Gland Biology and Neoplasia, v.5, n.2, p.165-185. 2000.

MATTHES, A. G. Z. et al. Biópsia do linfonodo sentinela para o câncer de mama com anestesia local. Revista Brasileira de Mastologia. v.20, n.4, p.170-176, 2010.

MEDINA D. Of mice and women: A short history of mouse mammary cancer research with an emphasis on the paradigms inspired by the transplantation method. Cold Spring Harb Perspect Biol, v.2, n.10, a 004523. 2010.

MIRANDA-VILELA, A. L.; YAMAMOTO, K.; MIRANDA, K. et al. Dextranfunctionalized magnetic fluid mediating magnetohyperthermia for treatment of Ehrlichsolid-tumor-bearing mice: toxicological and histopathological evaluations. Tumour Biol , v.35, n.4, p.1-13. 2013.

MIRANDA-VILELA, A. L.; GRISOLIA, C. K.; LONGO, J. P. F. et al. Oil rich in carotenoids instead of vitamins $\mathrm{C}$ and $\mathrm{E}$ as a better option to reduce doxorubicininduced damage to normal cells of Ehrlich tumor-bearing mice: hematological, toxicological and histopathological evaluations. J Nutr Biochem, v.25, n.11, p.11611176. 2014.

MIRANDA-VILELA, A. L.; PEIXOTO, R. C. A.; LONGO, J. P. F.; CINTRA, D.O.S.; PORTILHO, F. A.; MIRANDA, K. L. C. et al. Dextran-Functionalized Magnetic Fluid Mediating Magnetohyperthermia Combined with Preventive Antioxidant Pequi-Oil Supplementation: Potential Use Against Cancer. J Biomed Nanotechnol, v.9, n.7, p.1261-1271. 2013.

MIRANDA-VILELA, A. L.; PORTILHO, F. A.; DE ARAUJO, V. G. et al. The protective effects of nutritional antioxidant therapy on Ehrlich solid tumor-bearing mice depend on the type of antioxidant therapy chosen: histology, genotoxicity and hematology evaluations. J Nutr Biochem, v.22, n.11, p.1091-1098. 2011.

MIRANDA-VILELA, A. L. et al. Dextran-functionalized magnetic fluid mediating magnetohyperthermia for treatment of Ehrlich-solid-tumor-bearing mice: toxicological and histopathological evaluations. International Society of Oncology and BioMarkers (ISOBM). v.35, p.3391-3403, 2013.

MIRANDA-VILELA, A.L.; GRISOLIA, C. K.; LONGO, J. P. F.; PEIXOTO, R. C. A.; DE ALMEIDA, M. C.; BARBOSA, L. C. P.; ROLL, M. M.; PORTILHO, F. A.; ESTEVANATO, L. L. C.; BOCCA, A. L.; BÁO, S. N.; LACAVA, Z. G. M. Oil rich in 
carotenoids instead of vitamins $\mathrm{C}$ and $\mathrm{E}$ as a better option to reduce doxorubicininduced damage to normal cells of Ehrlich tumor-bearing mice: hematological, toxicological and histopathological evaluations. The Journal of nutritional biochemistry .v.25, p.1161-1176. 2014.

MIRANDA-VILELA, A.L.; PORTILHO, F. A.; DE ARAUJO, V. G.; ESTEVANATO, L. L.; MEZZOMO, B. P.; ALMEIDA SANTOS, M. F.; LACAVA, Z. G. The protective effects of nutritional antioxidant therapy on Ehrlich solid tumor-bearing mice depend on the type of antioxidant therapy chosen: histology, genotoxicity and hematology evaluations. The Journal of nutritional biochemistry, v.22, p.1091-1098. 2011.

MOGHIMI, S. M.; HUNTER, A. C.; MURRAY, J. C. Nanomedicine: current status and future prospects. FASEB J, v.19, n.3, p.311-330. 2005.

MOOS, G. E., et al. Growth of Ehrlich Ascites Tumors in ICR/Ha Swiss Mice by Isocyanates. Cancer Research, v.31, p.937-941. 1971.

MORAES, S. P.; CUNHA, A.; REIS NETO, J. A.; BARBOSA, H.; DUARTE, R. F. Modelo experimental de tumor de Walker. Acta Cir. Bras. v.15 n.4 São Paulo. 2000.

MORTON, D. L. et al. Technical Dentails ofvIntraoperative Lymphatic Mapping, John Wayne Institute for Cancer Treatment and Research, St John's Hospital and Health Center, Santa Monica, Calif . 1992.

MOTTA, V. T. Creatinina. In: R. Editorial (Ed.). Bioquímica Clínica: Princípios e Interpretações. Porto Alegre: Editora Médica Missau, Creatinina, p.232-246, 2003.

NAFISI, S.; MONTAZERI, M.; MANOUCHEHRI, F. The effect of Se salts on DNA structure. J Photochem Photobiol B, v. xxx, p. xxx, 2012.

NAGAI, S. T. M. Interleukin-4 and breast cancer. Breast Cancer, v.7, n.3, p.181-186. 2000.

NASCIMENTO, F. R. F. et al. Ascitic and solid Ehrlich tumor inhibition by Chenopodium ambrosioides L. treatment. Life Sciences. v.78, p.2650-2653. 2005.

NASCIMENTO, F. R. F.; CRUZ, G. V. B.; PEREIRA, O. V. S.; MACIDEL, M. C. G.; SILVA, L. A.; AZEVEDO, A. P.; BORROQUEIRO, E. S.B. Ascitic and solid Ehrlich tumor inhibition by Chenopodium ambrosioides L. treatment. Life Sciences v. 78, p. $2650-2653.2006$.

NCI. National Cancer Institute. Fact book. 1998. Disponível em www.nci.nih.gov Acesso em 01 de Dezembro de 2015.

NIH. National Institutes of Health, United States Department of Health and Human Services. v.2, n.1. 2013.

NISHIKAWA, M. Reactive oxygen species in tumor metastasis. Cancer Letters, v.266, p.53-59. 2008. 
NOVOTNY, L.; RAUKO, P.; KOMBIAN, S. B.; EDAFIOGHO, I. O. Selenium as a chemoprotective anti-cancer agent: reality or wishful thinking. Neoplasma, v.57, n.5, p.383-391. 2010.

OLIVEIRA, G.R.O. Desenvolvimento de Bioprocessadores para Produção de Biomassa de Levedira (Saccharomyces cerevisiae) Rica em Oragonoselênio. Dissertação de Mestrado. Universidade Federal do Paraná: Florianópolis. 2006.

OMS. Selenium, Environmental Health Criteria N $\square$ 58. World Health Organization, Geneva, Switzerland. 2012.

OZASLAN, M. et al. Ehrlich ascites carcinoma. African Journal of Biotechnology, v.10, n.13, p.2375-2378. 2011.

PAGET S. The distribution of secondary growths in cancer of the breast. Cancer Metastasis Rev. v.8, p.98-101. 1989.

PANKHURST, Q. A.; CONNOLLY, J.; JONES, S. K.; DOBSON, J. Applications of magnetic nanoparticles in biomedicine. J Phys D: Appl Phys, v. 36, p. 167-181, 2003.

PARISOTTO, E. B. Avaliação da atividade antitumoral do extrato bruto e supercrítico de cordia verbenacea. Dissertação de Mestrado. Centro de Ciências Biológicas, Universidade Federal de Santa Catarina: Florianópolis, 2010.

PAVON, L. F.; OKAMOTO, O. K. Aplicações de recursos nanobiotecnológicos em câncer. Einstein, v.5, n.1, p.74-77. 2007.

PEIXOTO, R.; MIRANDA-VILELA, A.; FILHO, J.; et al. Antitumor effect of free rhodium (II) citrate and rhodium (II) citrate-loaded maghemite nanoparticles on mice bearing breast cancer: a systemic toxicity assay. Tumor Biol, v.36, n.5, p.3325-3336. 2015.

PELEJA, M. et al. Avaliação comparativa da acurácia e da taxa de detecção dos corantes azul patente e azul de metileno na identificação do linfonodo sentinela em pacientes com câncer de mama. Anais do Congresso de Pesquisa, Ensino e Extensão- CONPEEX. 2013.

PERSSON, I. Estrogens in the causation of breast, endometrial and ovarian cancers evidence and hypotheses from epidemiological findings. J Steroid Biochem Mol Biol, v.74, p.357-64. 2000.

PETREK, J. A. ; HEELAN, M. C. Incidence of Breast Carcinoma-Related Lymphedema. American Cancer Society. New York; New York. 1998.

PINHEIRO, D. J. P. C. et al Linfonodos axilares em pacientes com câncer de mama: avaliação ultrassonográfica. Radiol Bras. v.47, n.4, p.240-244. 2014.

PINHEIRO, L. G. P., et al. Estudo experimental de linfonodo sentinela na mama da cadela com azul patente e Tecnécio Tc99m. Acta Cirúrgica Brasileira, v.18, n.6. 2003. 
PIRES, L. A.; DELGADO, G. L. Tratamento Sistemático do Câncer da Mama Hormonioterapia e Quimioterapia. Manual de Oncologia. São Paulo, BBS Editora, 2004.

PITORRE, M. et al. Passive and specific targeting of lymph nodes: the influence of the administration route. Eur. J. Nanomed. v.7, n.2, p.121-128. 2015.

PODGRABINSKA, S.; SKOBE, M. Role of lymphatic vasculature in regional and distant metastases. Microvascular Research. v.95, p.46-52, 2014.

PORTILHO, F. A.; ESTEVANATO, L. L. C.; MIRANDA-VILELA, A. L. et al. Investigation of a magnetohyperthermia system efficacy. J Appl Phys,109:07B307. 2011.

PORTILHO, F.A. Avaliação da Biocompatibilidade de Fluido Magnético à Base de Nanopartículas de Maghemita Recobertas por Polifosfato em Camundongos. Dissertação de Mestrado. Faculdade de medicina da Universidade de Brasília, 2007.

PORTILHO, F.A. o uso de nanoesferas de albumina na terapia fotodinâmica e magnetohipertermia do tumor de ehrlich. Tese. Faculdade de medicina da Universidade de Brasília, Brasília: 2011.

PORTILHO, F. A.; ESTEVANATO, L. L. C.; MIRANDA, A. L. V.; ALMEIDA, S. M. F. M.; LACAVA, B. M.; SIMIONI, A.; TEDESCO, A. C.; MORAIS, P. C.; LACAVA, Z. G. M. Investigation of a magnetohyperthermia system efficacy. J Appl Phys, v.109, n.7. p.109. 2011.

QUADROS, L. G. A.; GEBRIM, L. H. A pesquisa do linfonodo sentinela para o câncer de mama na prática clínica do ginecologista brasileiro. Rev Bras Ginecol Obstet. v.29, n.3, p.158-64. 2007.

QUIMBY, F. W.; LUONG, R. H. Clinical Chemistry of the Laboratory Mouse. Elsevier, San Diego, California, USA, p.171-216. 2007.

RAMAIAH, S. K. A toxicologist guide to the diagnostic interpretation of hepatic biochemical parameters. Food and Chemical Toxicology, v. 45, p. 1551-1557, 2007.

RAMOS, A. Xenotransplantação - Considerações Éticas. Revista Lusófona Ciência e Medicina Veterinária.v.1, p.1-7. 2007.

RAO, V. S. R. ; DYER, C. E. ; JAMEEL, J. K. A. et al. Potential prognostic and therapeutic roles for cytokines in breast cancer (Review). Oncol Rep. v.15, n.1, p.179-185. 2006.

RASHID, O. M.; NAGAHASHI, M.; RAMACHANDRAN, S. et al. Resection of the primary tumor improves survival in metastatic breast cancer by reducing overall tumor burden. Surgery. v.153, n.6, p.771-778. 2013.

RIBEIRO, L. R.; SALVADORI, D. M. F.; MARQUES, E. K. (Org). Mutagênese Ambiental. Canoas: Ulbra, 2003. 
RICHERT, M. M. et al. Atlas of Mouse Mammary Gland Development. Journal of Mammary Gland Biology and Neoplasia. v.5, n.2, p.227. 2000.

RICHMOND, A.; Su, Y. Mouse xenograft models vs GEM models for human cancer therapeutics. Dis Model Mech. v.1, n.2, p.78-82. 2008.

ROBBINS \& COTRAN, Robbins and Cotran Pathologic Basis of Disease. Saunders. Elsevier. Ed. 8. 2009.

ROBICHAUX, J. P.; HALLETT, R. M.; FUSELER, J.W. et al. Mammary glands exhibit molecular laterality and undergo left-right asymmetric ductal epithelial growth in MMTV-cNeu mice. Oncogene. v.34, n.15, p.2003-2010. 2015.

RODRIGUES, J. S.; SANTOS-MAGAlHAES N. S.; COELHO, L. C. B. B.; P. COUVREUR, P.; PONCHEL, R. Gref Novel core(polyester)-shell(polysaccharide) nanoparticles: protein loading and surface modification with lectins. Journal of Controlled Release. v.92, p.103-112. 2003.

ROSS, M. H. Atlas de histologia descritiva. Atmed. Porto Alegre, 2012.

RUSSO, I. H., RUSSO J. Mammary gland neoplasia in long-term rodent studies. Environ Health Perspect. v.104, n.9, p.938-967. 1996.

NAGARAJAN, S.; YONG, Z. Use of core/shell structured nanoparticles for biomedical applications, Recent Patents Biomed. v.1 p.34-42, 2008.

SADEGHIANI, N.; GUEDES, M.; OLIVEIRA, D. et al. Effects of Magnetic Field and Magnetoliposomes on Mice: Cytotoxicity and Genotoxicity Tests. Magnetics, IEEE Transactions, v.42, p.3605-3607. 2006.

SADEGHIANI, N. Avaliação dos Efeitos de Nanopartículas Magnéticas Recobertas com Ácido Poliaspártico no Tumor Sólido de Ehrlich na Presença de Campo Magnético. Tese de Doutorado. Faculdade De Medicina Universidade de Brasília,Brasília. 2008.

SAHOO, S. K.; PARVEEN, S.; PANDA, J. J. The present and future of nanotechnology in human health care. Nanomedicine, v.3, n.1, p.20-31. 2007.

SAIJO, Y.; TANAKA, M.; MIKI, M. et al. Proinflammatory Cytokine IL-1 $\beta$ Promotes Tumor Growth of Lewis Lung Carcinoma by Induction of Angiogenic Factors: In Vivo Analysis of Tumor-Stromal Interaction. J Immunol. v.169, n.1, p.469-475. 2002.

SANTANA, J. F. B.; SOLERA, M. A. G.; DA SILVA, S. W., GUEDES, M. H.; LACAVA, Z. G. M.; AZEVEDO, R. B.; MORAIS, P. C. Investigation of the interaction between magnetic nanoparticles surface-coated with carboxymethyldextran and blood cells using Raman spectroscopy. Journal of Magnetism and Magnetic Materials. v. 289, p. 452454, 2005.

SAROJA, M.; SANTHI, R.; ANNAPOORANI, S. Antioxidant potential of ethylacetate fraction of cynodon dactylon against ELA implanted swiss albino mice. Int J Pharm Biol Sci. v.3, n.2, p.415-419. 2012. 
SCHEARS, R. M. Acute liver failure in the United States. Annals of Internal Medicine, v.139, n.12, p.217-226, 2003.

SCHRAUZER, G. N. Anticarcinogenic effects of selenium. Cell Mol Life Sci. v.57, n.13, p.1864-1873. 2000.

SCHUH, J. C. L. Trials, Tribulations, and Trends in Tumor Modeling in Mice. Toxicologic Pathology, v.32, p.53-66, 2004

SCHWEIZER F. Cationic Pepitdes With Cancer-sective Toxicity. Eur J Pharmacol. v.625, p.190-194. 2009.

SHAH, Y. M.;AL-DHAHERI, M.;DONG, Y.; IP, C.; JONES, F. E.; ROWAN, B. G. Selenium disrupts estrogen receptor A signaling and potentiates tamoxifen antagonism in endometrial cancer cells and tamoxifen-resistant breast cancer cells. Molecular Cancer Therapeutics.2005.

SHARMA, S.; KELLY, T. K.; JONES, P. A. Epigenetics in cancer. Carcinogenesis, v.31, p.27-36. 2010.

SHIN, J. H. et al. In Vitro Sonographic Evaluation of Sentinel Lymph Nodes for Detecting Metastasis in Breast Cancer Comparison With Histopathologic Results. American Institute of Ultrasound in Medicine. J Ultrasound Med, v.23, p.923-928.2004.

SIEJA, K. Talerczyk M. Selenium as an element in the treatment of ovarian cancer in women receiving chemotherapy. Gynecol Oncol. v.93, n.2, p.320-327. 2004.

SOBIN, L. H.; WITTEKIND, C. H. Classification of malignant tumours. New York: WilleyLiss, ed.6. 2002.

SOLBERG, H. E.; PETITCLERC, C. Approved recommendation (1988) on the theory of reference values. Part 3. Preparation of individuals and collection of specimens for the production of reference values. Clin Chim Acta. v.177, n.3, p.3-11. 1988.

SUCHOCKI, P.; MISIEWICZ, I.; SKUPINSKA, K.; WACLAWEK, K.; FIJALEK, Z.; KASPRZYCKA-GUTTMAN, T. The activity of Selol in multidrug-resistant and sensitive human leukemia cells. Oncology Reports. v.18, p.893-899. 2007.

SUCHOCKI, P. I. M.; KATARZYNA, S.; KAROLINA, W.; ZBIGNIEW, F.; TERESA K. G. The Activity of Selol in Multidrug-Resistant and Sensitive Human Leukemia Cell. Oncology Reports. v.18, p.893-899, 2007.

SUGIURA, K. Effect of Various Compounds on the Ehrlich Ascites Carcinoma. Cancer Res .v.13, n.6, p.431-441. 1953.

SUTHERLAND, R. J. Biochemical evaluation of the hepatobiliary system in dogs and cats. Vet Clin North Am Small Anim Pract. v.19, p.899-927. 1989

TARTAJ, P.; MORALES, M. D. P.; VEINTEMILLAS-VERDAGUER, S.; GONZÁLEZCARRENO, T.; SERNA, C. J. The preparation of magnetic nanoparticles for 
applications in biomedicine. Journal of Physics D: Applied Physics, v.36, p.R182-R197. 2003.

TAŞKIN, E. İ. Ehrlich Ascites Tümörü ile Balb-C Farelerde Oluşturulmuş Solid Tümör Modelinde Curcuminin Apoptoz Üzerine Etkileri. İstanbul, Üniversitesi Sağlık Bilimleri Enstitüsü Tıbbi Biyoloji Anabilim Dalı. İstanbul. 2002.

TAVASSOLI, F. A. Classification of metaplastic carcinomas of the breast. Pathol Annu, v.27, n.2, p.89-119. 1992

TESTA, L.; MANO, M. Quimioterapia em câncer de mama. Revista brasileira de Mastologia. v.20, n.4. 2010.

THRALL, M. A.; BAKER, D. C.; CAMPBELL, T. W.; DENICOLA, D.; FETTMAN, M. J.; LASSEN, E. D.; REBAR, A.; WEISER, G. Hematologia e Bioquímica Clínica Veterinária. Editora Roca, São Paulo, Brazil, ed.1, 2007.

TORCHILIN, V. P. Targeted pharmaceutical nanocarriers for cancer therapy and imaging. $A A P S$ J, v. 9, n. 2, p. E128-E147, 2007.

TRUEBA, G. P.; SANCHEZ, G. M.; GUILIANI, A. Oxigen free and antioxidant defense mechanism in cancer. FronBiosci. v.9, p.2029-2044. 2004.

TZU-CHIEH, C.; CHIA-SIU W.; SHIN-CHEH, C.; MIIN-FU, C. Metaplastic carcinomas of the breast. J Surg Oncol. v.71, p.220-225. 1999.

USA. American Cancer Society, Inc. Câncer de Mama. O que é câncer?. 2013.

USP. ModelosBiológicos. Disponível em: http://www.biot.fm.usp.br/index.php?mpg=03.00.00\&tip=CAMUNDONGO\&id_ani=2 \&parametros $=$ sim. Acessado em 28/04/2013.

VAN DEN BROECK, W.; DERORE, A.; SIMOENS, P. Anatomy and nomenclature of murine lymph nodes: Descriptive study and nomenclatory standardization in BALB/canncrl mice. J Immunol Methods. v.312, n.1, p.12-19. 2006.

VERÇOSA, D. J.; MELO, M. M.; DANTAS-BARROS, A. M.; GOMES, A.M.; SILVA JUNIOR, P. G.; LAGO, E. P. Quadro hematologico e peso do baço de camundongos com tumor de Ehrlich na forma sólida tratados com Agaricus blazei. Rev Bras Farmacogn. v.14, p.32-34. 2004.

VERDE, E. L.; LANDI, G. T.; CARRIAO, M. S. et al. Field dependent transition to the nonlinear regime in magnetic hyperthermia experiments: Comparison between maghemite, copper, zinc, nickel and cobalt ferrite nanoparticles of similar sizes. Aip Advances. v.2, n.3, p.23. 2012.

VIDAL, I. F.; MARTINS, I. V.; LIRA, R. A.; TEIXEIRA, M. N.; FAUSTINO, M. A. G.; ALVES, L. C. Níveis séricos da gama-glutamiltransferase em cães com e sem infecção natural por Leishmania Chagasi. Arquivo Brasileiro de Medicina Veterinaria $e$ Zootecnia, v. 61, n. 3, p. 749-751, 2009. 
VILELA, A.L.M. Nanomateriais e antioxidante no tratamento de tumor de mama em camundongos Swiss. Pós-Doutorado, Universidade de Brasília - UnB, Departamento de Genética e Morfologia, Laboratório de Genética, 2009.

VISVADER, J. E. Keeping abreast of the mammary epithelial hierarchy and breast tumorigenesis. . v.3, n.22, p.2563-2577. 2009.

VORONOV, E.; SHOUVAL, D. S.; KRELIN, Y. et al. IL-1 is required for tumor invasiveness and angiogenesis. Proc Natl Acad Sci USA. v.100, n.5, p.2645-2650. 2003.

WAINSTEIN, A. A new mouse model for evaluating theimmunotherapy of human colorectal cancer. Cancer Res, v.61, p.8520-8527. 2001.

WANG, H.; YING, Z. et al. Enhanced anti-tumor efficacy by co-delivery of doxorubicin and paclitaxel with amphiphilic methoxy PEG-PLGA. copolymer nanoparticles, Biomaterials 32. v.32, p.8281-8290. 2011.

WEIGELT, B.; JOHANNES, L. et al Breast cancer metastasis: markers and models. Nature Reviews Cancer. v.5, p.591-602. 2005.

WEINBERG, H. et al Modelling the Molecular Circuitry os Cancer. Nature Reviews Cancer. v.2, p.331-341. 2002.

WEINBERG, R.A. A biologia do câncer. Porto Alegre: Artmed. p. 640-646. 2015.

WEISS DJ, Wardrop KJ (Eds). Schalm's Veterinary Hematology. 6th ed. Ames: Wiley Blackwell, 2010.

WERNER, B.; MOLL, R.; POREMBA, C.; HOLLAND, R. et al., Common adult stem cells in the human breast give rise to glandular and myoepithelial cell lineages: a new cell biological concept. Laboratory Investigation; A Journal Of Technical Methods And Pathology. v.82, n.6, p.737-746. 2002.

WHANGER, P. D. Selenium and its relationship to cancer: An update. . Br J Nutr v.91, p.11-28. 2004.

WHO. World Health Organization. Cancer Control: knowledge into action: who guide for effective programmes: early detection. Switzerland: WHO, 2007.

WHO. World Health Organization. Cancer Control: knowledge into action: who guide for effective programmes: early detection. Switzerland: WHO, 2013.

WITZ, I. P. The Tumor Microenvironment: The Making of a Paradigm. Cancer Microenviron. v.2, n.1, p.9-17. 2009.

WORKMAN, P.; ABOAGYE, E. O.; BALKWILL, F. et al. Guidelines for the welfare and use of animals in cancer research. Br J Cancer. v.102, n.11, p.1555-1577. 2010.

WORKMAN, P. E. O.; ABOAGYE, F. B.; BALMAIN, A.; BRUDER, G.; CHAPLIN, D. J.; DOUBLE, J. A.; EVERITT, J.; FARNINGHAM, D. A. H.; GLENNIE, M. J.; 
KELLAND, L. R.; ROBINSON, V.; STRATFORD, I. J.; TOZER, G. M.; WATSON, S.; WEDGE, S. R.; ECCLES, S. A. An ad hoc committee of the National Cancer Research Institute. Guidelines for the welfare and use of animals in cancer research. British Journal of Cancer, v.102, p.1555 - 1577. 2010.

JASTRZEBSKI, Z.; CZYZEWSKA-SZAFRAN, H.; REMISZEWSKA, M.; FIJALEK, Z.; FITAK, B. A.; SUCHOCKI, P. Pharmacokinetics of Selol, a new agent containing selenium, in rats. Drugs Expl Clin Res, v. 23, n. 1, p. 7-11, 1997.

ZACHARA, B. A. J. Trace Elem Electrolytes Health Dis. v.6, p.137-15. 1992.

ZAGO, M. A.; FALCÃO, R. P.; PASQUINI, R. Hematologia - Fundamentos e Prática. São Paulo, Editora Atheneu, 2004.

ZHANG, X.; WENG, W.; XU, W. et al. Prognostic significance of interleukin 17 in cancer: a meta-analysis. Int J Clin Exp Med . v.7, n.10, p.3258-3269. 2014.

ZHAO, SHUANGPING \& O. D. SHERWOOD. Mooclonal Antibodies Specific for Rat Relaxin. X. Endogenous Relaxin Induces Changes in the Histological Characteristics of the Rat Vagina During the Second Half of Pregnancy. Endocrinology Printed.v.139, n.11. p.4726-4734. 1998. 
ANEXOS

ANEXO 1: APROVAÇÃO DO COMITÊ DE ÉTICA

Universidade de Brasília

Instituto do Cilonclas Bolologleas
Comited do Etica no Uso Animal

UnBDOC: $44783 / 2013$

Responsável: Ana Luisa Miranda-Vilela

Título:Nanoparticulas magnéticas e nanocápsulas contendo compostos ricos em selênio no tratamento do adenocarcinoma mamário de Ehrlich em camundongos Swiss.

Parecer: Favorável

Situação: [ ] Aprovado [ ] Pendente [ ] Reprovado [ ] Não Julgado

O presente projeto elucida o delineamento experimental mediante análise estatística, atende às normas de alojamento, anestesia, analgesia e eutanásia dos animais, bem como ao descarte (congelamento e incineração).

Mediante o exposto, sou de parecer favorável à aprovação do mesmo.

Brasília, 07 de junho de 2013.

(Carimbo da CEUA - IB) 
ANEXO 2: DECLARAÇÃO DO COMITÊ DE ÉTICA

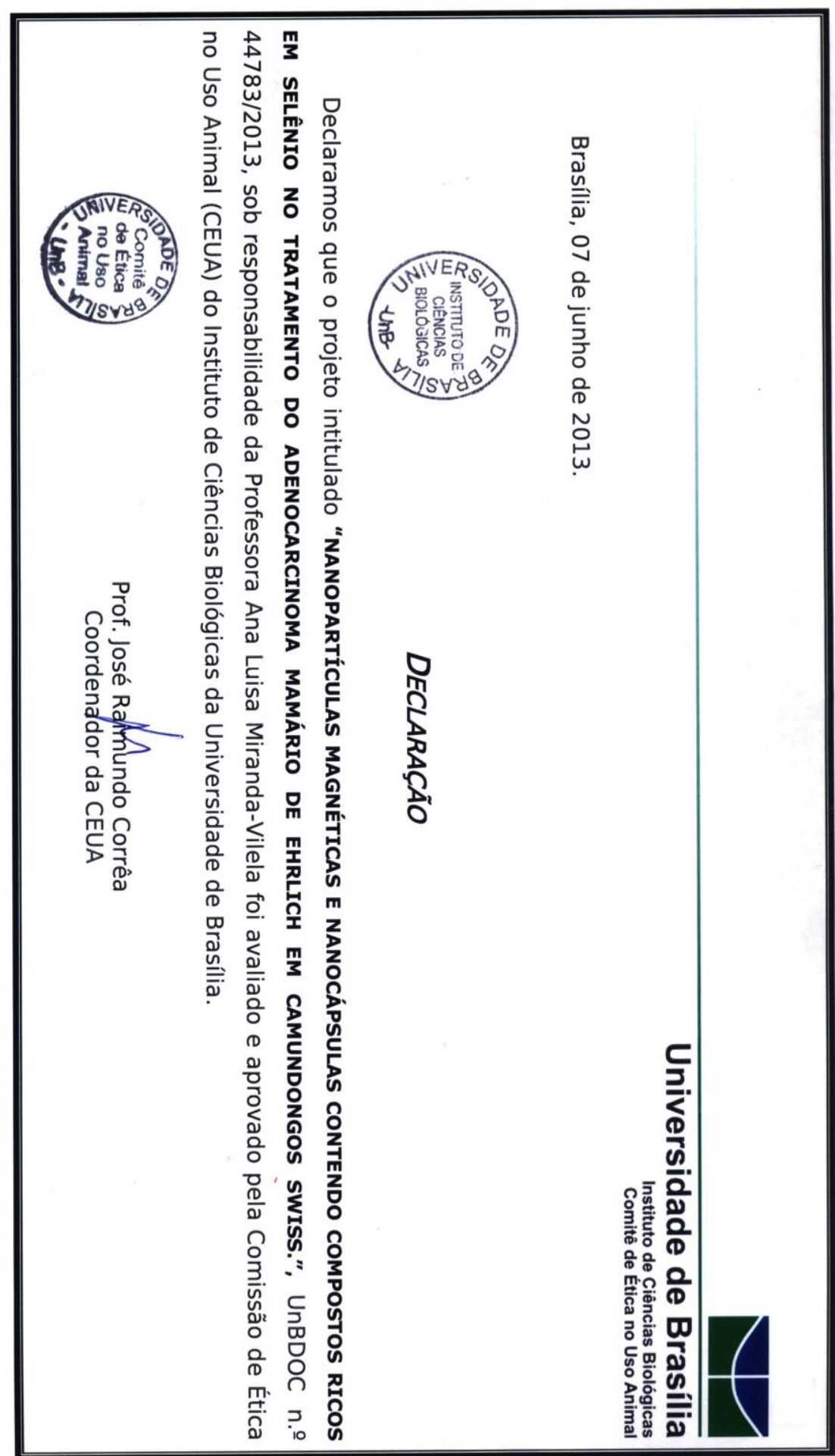


ANEXO 3: PROTOCOLO O1 - AZUL DE TRIPAN INOCULADO

\begin{tabular}{|c|c|}
\hline \multicolumn{2}{|c|}{ Coloração } \\
\hline $50 \mu \mathrm{L}$ (ducto mamário principal) & Azul de Tripan a $2 \%$ \\
\hline Fixação & Tempo \\
\hline Formalina $10 \%$ Nacl 0,9\% & 24 horas \\
\hline \multicolumn{2}{|c|}{ Desengorduração } \\
\hline \multicolumn{2}{|c|}{ Desidratação } \\
\hline Álcool 70\% & 1 hora \\
\hline Álcool 80\% & 1 hora \\
\hline Álcool 90\% & 1 hora \\
\hline Álcool 100\% 3X & 1 hora \\
\hline Acetona PA & 72 horas \\
\hline \multicolumn{2}{|c|}{ DIAFANIZAÇÃO } \\
\hline Xilol naftalina $20 \%$ & 72 horas \\
\hline \multicolumn{2}{|c|}{ Reidratação } \\
\hline Álcool 100\% 3X & 1 hora \\
\hline Álcool 90\% & 1 hora \\
\hline Álcool 80\% & 1 hora \\
\hline Álcool 70\% & 1 hora \\
\hline Água & "overnight". \\
\hline
\end{tabular}


ANEXO 4: PROTOCOLO 02 - AZUL DE TOLUIDINA IN SITU

\begin{tabular}{|c|c|}
\hline Fixação & Tempo \\
\hline Formalina $10 \%$ Nacl $0,9 \%$ & 24 horas \\
\hline \multicolumn{2}{|c|}{ Desengorduração } \\
\hline Acetona PA & 72 horas \\
\hline \multicolumn{2}{|c|}{ Desidratação } \\
\hline Álcool 70\% & 1 hora \\
\hline Álcool 80\% & 1 hora \\
\hline Álcool 90\% & 1 hora \\
\hline Álcool 100\% 3X & 1 hora \\
\hline \multicolumn{2}{|c|}{ COLORAÇÃO IN SITU } \\
\hline Água & "overnight" \\
\hline Azul de toluidina $2 \%$ & 30 minutos \\
\hline \multicolumn{2}{|c|}{ Background } \\
\hline Álcool $70 \% 100 \mu 1$ de acetona P A & 1 Hora \\
\hline Álcool 70\% & 1 hora \\
\hline \multicolumn{2}{|c|}{ Diafanização } \\
\hline Xilol & 24 horas \\
\hline Xilol naftalina $20 \%$ & 72 horas \\
\hline \multicolumn{2}{|c|}{ Reidratação } \\
\hline Álcool 100\% 3X & 1 hora \\
\hline Álcool 90\% & 1 hora \\
\hline Álcool 80\% & 1 hora \\
\hline Álcool 70\% & 1 hora \\
\hline
\end{tabular}


ANEXO 5: PROTOCOLO 03 - AZUL DE TRIPAN INOCULADO E AZUL DE TOLUIDINA

\begin{tabular}{|c|c|}
\hline \multicolumn{2}{|c|}{ Coloração } \\
\hline $50 \mu \mathrm{L}$ (ducto mamário principal) & Azul de Tripan a $2 \%$ \\
\hline Fixação & Tempo \\
\hline Formalina $10 \%$ Nacl $0,9 \%$ & 24 horas \\
\hline \multicolumn{2}{|c|}{ Desengorduração } \\
\hline Acetona PA & 72 horas \\
\hline \multicolumn{2}{|c|}{ Desidratação } \\
\hline Álcool 70\% & 1 hora \\
\hline Álcool 80\% & 1 hora \\
\hline Álcool 90\% & 1 hora \\
\hline Álcool 100\% 3X & 1 hora \\
\hline \multicolumn{2}{|c|}{ COLORAÇÃO IN SITU } \\
\hline Água & "overnight" \\
\hline Azul de toluidina $2 \%$ & 1 horas \\
\hline \multicolumn{2}{|c|}{ Background } \\
\hline Álcool $70 \% 100 \mu 1$ de acetona P A & 1 Hora \\
\hline Álcool 70\% & 1 hora \\
\hline \multicolumn{2}{|c|}{ Diafanização } \\
\hline Xilol & 24 horas \\
\hline Xilol naftalina $20 \%$ & 72 horas \\
\hline \multicolumn{2}{|c|}{ Reidratação } \\
\hline Álcool 100\% 3X & 1 hora \\
\hline Álcool 90\% & 1 hora \\
\hline Álcool 80\% & 1 hora \\
\hline Álcool 70\% & 1 hora \\
\hline
\end{tabular}


ANEXO 6. PREPARAÇÃO DA NPSEL

\begin{tabular}{|c|c|c|c|c|}
\hline \multicolumn{5}{|c|}{ Constituintes dissolvidos separadamente por 10 min sob agitação magnética. } \\
\hline & Constituinte & Quantidade & Solvente & Quantidade \\
\hline 1 & $\begin{array}{l}\text { Poli ácido } \\
\text { láctico-co-glicólico } \\
(\mathrm{PLGA})\end{array}$ & $0,150 \mathrm{~g}$ & Acetona & $6 \mathrm{~mL}$ \\
\hline 2 & $\begin{array}{c}\text { Epikuron ( } \\
\text { fosfatidilcolina de soja) }\end{array}$ & $0,150 \mathrm{~g}$ & $\begin{array}{l}\text { metanol } \\
\text { e acetona }\end{array}$ & $1 \mathrm{~mL}$ e $2 \mathrm{~mL}$ \\
\hline 3 & Polaxamer 407 & $0,150 \mathrm{~g}$ & $\begin{array}{r}\text { Tampão } \\
\text { fosfato } 0,1 \mathrm{M} \mathrm{pH} \\
7.4\end{array}$ & $4,5 \mathrm{~mL}$ \\
\hline 4 & $\begin{array}{l}\text { óleo de soja e } \\
\text { Selol }\end{array}$ & $\begin{array}{l}100 \mathrm{mg} \text { e } 100 \\
\mathrm{mg}\end{array}$ & $\begin{array}{l}\quad 6 \mathrm{~mL} \\
\text { acetona }\end{array}$ & - \\
\hline & \multicolumn{4}{|c|}{ Metodologia } \\
\hline 1 & \multicolumn{4}{|c|}{ Após total dissolução de cada constituinte misturou-se, sob agitação o PLGA e o Epikuron. } \\
\hline 2 & $\begin{array}{r}\text { Em seguida e ap } \\
\text { agitação, o óleo e deixou }\end{array}$ & $\begin{array}{l}\text { mistura no iter } \\
\text { min. }\end{array}$ & 1 da metodologia & -se ainda sob \\
\hline 3 & $\begin{array}{l}\text { Manteve o polax } \\
\text { mantendo por } 30 \text { min em }\end{array}$ & $\begin{array}{l}\text { sitação e gotejo } \\
\text { ambiente. }\end{array}$ & à mistura do iten & netodologia, e \\
\hline & & Fases & & \\
\hline & - Fase aquosa tampã & ontendo o ten & tivo polaxamer & \\
\hline 10 & A evaporação foi sob & $\begin{array}{r}\text { Observa } \\
\text { luzida no rota- }\end{array}$ & porador, até a re & volume para \\
\hline
\end{tabular}

